\title{
Modernising the Law on Oaths \& Affirmations
}

\author{
Graham McBain ${ }^{1,2}$ \\ ${ }^{1}$ Peterhouse, Cambridge, UK \\ ${ }^{2}$ Harvard Law School, USA \\ Correspondence: Graham McBain, 21 Millmead Terrace, Guildford, Surrey GU2 4AT, UK. E-mail: \\ gsmcbain@aol.com
}

Received: November 11, 2019 Accepted: December 23, 2019 Online Published: January 19, 2020

doi:10.5539/ilr.v9n1p1

URL: https://doi.org/10.5539/ilr.v9n1p1

\section{INTRODUCTION}

In modern times we are witnessing social change at an increasing rate as well as globalisation. Against this background it is important that English law keeps up-to-date. However, many legal formalities of the past have become obsolete today. ${ }^{1}$ This article considers one set of legal formalities. The requirement imposed on a person, in various situations, to give an oath or affirmation. The two words are connected since an oath comprises a religious affirmation. Thus, an oath is a type of affirmation or assertion - these words being synonyms. ${ }^{2}$ And, an affirmation is the same as a declaration. ${ }^{3}$ Hence, sometimes, the words affirmation and declaration are used interchangeably. Oaths, affirmations and declarations may be oral or written.

In religious societies such as in Biblical times - as well as in later Anglo-Saxon and medieval England - the oath was an integral feature. Especially, in legal and ecclesiastical spheres. The oath was designed to be morally binding. However, it was not (generally) legally binding (enforceable) apart from in legal proceedings, where the crime of perjury could be held to have been committed if a false oath was given. ${ }^{4}$ By means of an oath a person swore to (that is, asserted or declared) the truth of something (an assertory or declaratory oath) or promised to do something (a promissory oath). The moral sanction for breach of an oath was the widespread religious belief in English society that an oath breaker would be severely punished by (the Christian) God. Against this background, English law obliged certain people to give an oath in various situations. This was (often) prior to taking up a Crown office. Or in transactions concerning land, where oaths of homage or fealty were usually required. If a person refused or neglected to give an oath when legally required, sometimes, a sanction was imposed by English statute law. However, this was not invariable.

By the $17^{\text {th }}$ century, opposition to giving an oath was espoused by many Quakers and other religious dissenters on the basis that Christ had opposed the giving of oaths. And, by Victorian times, the law on when oaths were legally required was in disarray. Also, the form of the required oath was, often, uncertain or the wording made little sense, being archaic. Further, many people refused to give oaths on the basis that they were agnostic, atheist or not of the Christian religion. Or, that they did not believe in monarchical government - many oaths being given to the Crown in person. Besides, many argued, if an oath was not legally binding, what was the point ? The Promissory Oaths Act 1868 (the ' 1868 Act') was a compromise between those who argued for the abolition of all oaths and those who - mainly for religious reasons - argued that they still engendered a sense of moral responsibility in the oath giver. As it was, the 1868 Act simplified the occasions on which an oath was legally required as well as the form of some of them. It also provided for the giving of a (non-religious) affirmation in place of an oath. In hindsight, however, those dissenters who argued for the abolition of most (or

\footnotetext{
${ }^{1}$ e.g. for the legal formalities in respect of documents intended to have legal effect, see GS McBain, Legal Documents - Modernising the Formalities (2019) International Law Research, vol 8, no 1, pp 1-29.

${ }^{2}$ Compact Edition of the Oxford English Dictionary ('OED')(1971, assertion) '4. The action of declaring or positively stating; declaration, affirmation, averment.'

${ }^{3}$ e.g. Stroud's Judicial Dictionary of Words and Phrases (4 ${ }^{\text {th }}$ ed, 1973), vol 3 (oath) citing the Interpretation of Acts Act 1850, s 4 'In Acts of Parliament passed since the end of 1850, 'the words 'oath', 'swear' and 'affidavit' shall include affirmation, declaration, affirming, and declaring, in the case of persons by law allowed to declare or affirm instead of swearing.' See also Interpretation Act 1889, s 3 'The expressions 'oath' and 'affidavit' shall, in the case of persons for the time being allowed by law to affirm or declare instead of swearing, include affirmation and declaration, and the expression 'swear' shall, in the like case, include affirm and declare.' See also Perjury Act 1911, s 15(2) and the Commissioners for Oaths Act 1889, s 11 (oath includes affirmation and declaration).

${ }^{4}$ The law on perjury was consolidated in the Perjury Act 1911. For the historical development of the law on perjury, see F Pollock \& FW Maitland, The History of English Law before the time of Edward I (1968 rep), vol 2, pp 541-3. See also 29.
} 
all) oaths in 1868 were right, for their retention since 1868 became increasingly problematic, requiring further piecemeal legislation. Further, their death knell was, effectively, sounded by the Oaths Act 1888 which provided that the validity of an oath was unaffected by the fact the giver had no religious belief. Yet, the very nature - and purpose - of an oath was that it comprised (and still does) a religious affirmation !

This article, therefore, argues that any legal requirement to give an oath (or an affirmation) at common law should be abolished. ${ }^{5}$ And, that all oaths (and affirmations) required by legislation should be replaced by a statutory declaration. ${ }^{6}$ One which should only be required in a few instances. ${ }^{7}$

If these changes were made, this would remove a large body of antiquated legislation and legal writing on oaths and affirmations as well as save much wasted time, cost and administration. Would anyone object - especially, those empowered to administer oaths ? I think not. ${ }^{8}$ Modernisation of this area of law will bring it into the $21^{\text {st }}$ century. It will also acknowledge the fact that many people are not religious today (such that an oath means nothing to them) as well as that - even if they are religious and of the Christian religion - many still object to giving an oath.

In conclusion, this article argues for the abolition of any common law requirement to give an oath (or affirmation). And, that any statutory oath (or affirmation) should be transmuted into a statutory 'declaration'. Further, the crime of perjury should be abolished - to be replaced by a crime of making a false statutory declaration.

\section{NATURE OF OATHS AND AFFIRMATIONS}

Oaths comprise religious affirmations. They have been categorised into assertory (also called, declaratory) oaths and promissory oaths. Tillotson stated:

An assertory [also called a declaratory] oath is when a man affirms or denies upon oath a matter of fact, past or present: when he swears that a thing was, or is so, or not so. A promissory oath is a promise confirmed by an oath, which always respects something that is future; and if the promise be made directly and immediately to God, then it is called a vow, if to men, an oath. ${ }^{9}$

Thus, an oath is a religious declaration at base - as Cicero (106-43 AD) pointed out ${ }^{10}$ and as the Catholic church continues to point out. ${ }^{11}$ Further, it is, often, sworn upon a sacred object such as the Bible (the gospels) or an altar. ${ }^{12}$ The purpose of requiring an oath is to bind a person morally. Comprising as it does an invocation of God (or a God) ${ }^{13}$ there is no real point in a person giving (delivering) an oath if the same does not believe in God (or a God). Indeed, it is meaningless. Therein, lies part of the problem with legally requiring an oath in modern times since, today, a considerable portion of English society does not believe in a Christian (or other) God. Thus,

\footnotetext{
${ }^{5}$ This would not prevent a person giving an oath, if they wanted. Only any legal requirement to do so.

${ }^{6}$ The word 'declaration' is a more intelligible (and commonly used) word than the older synonym, 'affirmation'.

${ }^{7}$ There would seem to be benefit in requiring a declaration of allegiance to be given by : (a) those enlisting in the armed services; (b) aliens, on naturalisation - albeit, whether a person legally owes allegiance (for the purpose of the Treason Acts or otherwise) has never depended on whether they have given such an oath.

${ }^{8}$ The only people likely to object would be those Commissioners of Oaths who make a large sum of money from administering oaths. However, such must be rare, given that the fees for administering oaths are low.

${ }^{9} \mathrm{~J}$ Tillotson, The Lawfulness and Obligation of Oaths. A Sermon preached at Kingston upon Thames, July, 21, 1681. Cf. Catholic Church, The Code of Canon Law (English trans, Collins 2001), canon 1191(1) 'A vow is a deliberate and free promise made to God, concerning some good which is possible and better. The virtue of religion requires that it be fulfilled.' See also JE Tyler, Oaths, their Origin, Nature and History (1834), p 257. He also noted that declaratory oaths were, usually, distinguished into: (a) judicial; and (b) extra-judicial, oaths. The division of oaths into assertory and promissory ones, appears age old (possibly, reflecting the fact that assertory ones were used for legal proceedings while the others relating to contracts, marriage etc). See ASB Mercer, The Oath in Babylonian and Assyrian Literature (1912), pp 14-5.

${ }^{10}$ CR Edmonds, Cicero's Three Books of Offices (1880), book 3, p 159 'an oath is a religious affirmation; but what you solemnly promise, as if the deity were witness, to that you ought to adhere...he.... who violates an oath, violates faith.' Ibid, 'the word fides, of faithfulness, is no other than a performance of what we have promised.' Fides (faith) was also treated as a God by the Romans. Hence, a promise to that God was an oath.

${ }^{11}$ Code of Canon Law, n 9, canon 1199(1) 'An oath is the invocation of the divine name as witness to the truth. It cannot be taken except in truth, judgement and justice.' Ibid, canon 1200(1) 'A person who freely swears on oath to do something is specially obliged by virtue of religion to fulfil that which he or she asserted by the oath.'

${ }^{12}$ Fleta, Selden Society, vol 99, p 65 'An oath is an affirmation or denial of something, strengthened by swearing upon a sacred object.'

${ }^{13}$ Tillotson, n 9, p B 3 'An oath is an invocation of God, or an appeal to him as a witness of the truth of what we say.'
} 
they do not believe the breach of any oath they give, to be an act of sacrilege. That is, an act which will incur severe moral, or even physical, consequences. ${ }^{14}$

Prior to considering the history of oaths and affirmations, it may be noted there are various legal texts on oaths. ${ }^{15}$ Most of these texts are now obsolete in many particulars. Halsbury, Laws of England also contains material on oaths. ${ }^{16}$

\section{HISTORY OF THE OATH}

(a) Oaths in Ancient Times

The oath is a declaration made in the 'presence' of a deity. That is, making the deity a witness. It is a 'token' - a sign that a person has bound himself to do something. ${ }^{17}$ The English word 'oath' comes from the Anglo-Saxon and Germanic 'oth' (eoth) and linguistically (and, perhaps, etymologically) the word likely derived from the Hebrew 'oth', meaning a token or sign. ${ }^{18}$ In giving an oath a person is invoking God (or a God or the Gods) to punish him if he does not, then, fulfil his oath. In short, the oath giver delivers himself (that is, hands himself over) to his deity for punishment, if he breaks his oath. Phillips stated:

It is calling upon God to witness what we say, and invoking his vengeance, if, what we say, be false [i.e. untrue]. ${ }^{19}$

In ancient times, oaths were (often) given in a religious and constitutional context. For example, by kings when entering into treaties. They were also given in a commercial context. For example, to reinforce an oath giver's promise to fulfil a contract. Also, in a judicial context - especially to confirm the veracity of evidence given by a party in court. The degree to which societies (including courts) accorded the oath as evidence of a person being legally bound much depended on the status of religious observance in that society. Thus, Babylonian, Biblical, Roman and Anglo-Saxon society all regarded oaths as evidence of a person being bound morally (but not legally - save where the law expressly provided) and a person who breached their oath was, often, treated as a person of 'ill fame'. That is, disgraced - dedecus, in Republican Rome. ${ }^{20}$ This had important social consequences. For example, in early Rome, an oath breaker would have been (likely) treated as an outcast - one not acceptable in 'good' society. In Babylonian and Hebrew society it may also have invited physical retribution. So too, in Scandinavian and Anglo-Saxon society. ${ }^{21}$

\section{(b) Manner of giving the Oath}

In ancient times, the oath was (often) performed in a religious setting. Such as before an altar. Or, swearing on a religious text such as the Bible. This, in order to re-inforce its moral intent. Also, there were (usually) witnesses attendant when an oath was given - although there did not have to be. Further, in a commercial or treaty context,

\footnotetext{
${ }^{14}$ WH Buckler, The Origin and History of Contract in Roman Law (1895), p 4 (commenting on the earliest law) 'If an agreement has been solemnly made in the presence of the gods, its breach was punishable as an act of gross sacrilege.' He also noted that an oath was morally binding in the time of Cicero 'though it then had no legal force.'

${ }^{15}$ See: (a) TW Braithwaite, Oaths in Chancery ( $2^{\text {nd }}$ ed, 1864); (b) TW Braithwaite, Oaths in the Supreme Court of Judicature $\left(4^{\text {th }}\right.$ ed, 1881); (c) R Cole, Oaths in Common Law (1859); (d) WJ Fell \& AG Keats, Boland and Sayer on, Oaths and Affirmations $\left(1^{\text {st }}\right.$ ed, 1953; $2^{\text {nd }}$ ed, 1961); (e) JJ Dillon, Essay on the History and Effect of the Coronation Oath (1807); (f) RP Finch, Use and Abuse of Oaths Judicially Taken (1789): (g) C Ford, Handbook on Oaths ( $8^{\text {th }}$ ed, 1910); (h) R Garnet, Book of Oaths and the Severall Forms thereof (1715); (i) E Lake, Memoranda touching the Oath ex Officio (1662); (j) Oaths, Ancient and Modern and their Several Forms (1689); (k) R Powell, Explanation of the Old Oath of Legeance (1641); (1) R Richardson, Treatise of Oaths (1675); (m) J Stileman, Discourse of the Nature and Obligation of Oaths (1662); (n) FA Stringer, Oaths and Affirmations $\left(1^{\text {st }}\right.$ ed, 1889, last ed, $4^{\text {th }}$ ed, 1927); (o) Treatise of the Oath of Supremacy (1679); (p) JE Tyler, Oaths, their Origin, Nature and History (1834); (q) C White, Of Oathes, their Object, Forme and Bond (1627). See also Tillotson, n 9 and SM Phillips, Treatise on the Law of Evidence (1814). See also a non-legal text, C Condren, Argument and Authority in Early Modern England, The Presupposition of Oaths and Offices (2006).

${ }^{16}$ Halsbury, Laws of England $\left(5^{\text {th }} \mathrm{ed}\right)$.

${ }^{17}$ On the nature of the token, see GS McBain, Abolishing the Doctrine of Consideration [2018] International Law Research, vol 7, no 1, pp 1-104.

${ }^{18}$ Ibid, p 14.

${ }^{19}$ Phillips, n 15, p 12. See also Tyler, n 9, p 9. Mercer, n 9, p 42 'The taking of an oath [among the Babylonians and Assyrians] was essentially a religious ceremony, being made in the presence of some representation of deity [i.e. in a temple, on an altar etc]; it became more solemn and powerful if a god in person were called to witness; it involved especially the almost universal ritual of raising the hand; [ie. raising the right hand in prayer] and it resulted in a curse on those who dared to take it unworthily, or break it.'

${ }^{20}$ McBain, n 17, pp 14, 40-1. CT Lewis \& C Short, A Latin Dictionary (dedecus) 'disgrace, dishonour, infamy, shame'. For the use of the oath in the Roman legal context, see WW Buckland (rev. P Stein), A Textbook of Roman Law ( ${ }^{\text {rd }}$ ed, 1966).

${ }^{21}$ For example, the Vikings swore oaths on the hilt of their sword, to evidence that they might be killed with the same if they breached their oath. As for Babylonian society, RF Harper, The Code of Hammurabi, King of Babylon (c 2250), p 11 'If a man, in a case (pending judgment)[i.e. in court], bear false (threatening) witness [i.e. perjures himself] or do not establish the evidence [i.e. cannot prove his evidence], if that case be a case involving life, that man shall be put to death.'
} 
an oath was (often) accompanied by other external evidentiary acts (that is, signs or tokens) such as a handshake or a drink..$^{22}$ This, to provoke the memory of the oath giving as well as the conclusion of the contract, treaty or act in the context of which the oath was given. Thus, in Babylonian and Biblical times, the handshake (hand clasp) - or, sometimes, the hand strike ${ }^{23}$ - was employed to evidence the fact that negotiations had ended and that an agreement had been reached. ${ }^{24}$ In Scandinavian (and Viking) society, the handclasp (handsel, handseal) rather than a handshake or handstrike - seems to have been predominant form of act, there being a clasp of the (right) arm of the contracting parties up to the elbow, a sign of good intent and friendship since it inhibited the use of the sword arm. Such also seems to have occurred in Anglo-Saxon society. At least, in the Viking part of England after the Vikings invaded and settled in England from 866 AD. ${ }^{25}$

In conclusion, since ancient times, an oath has comprised a declaration, invoking a deity as a witness and inviting divine punishment for breach. Thus, an oath is a 'token' - a sign - that a person has bound himself to do something. For example, to tell the truth or to undertake an act.

\section{OATHS IN ANGLO-SAXON TIMES}

The Anglo-Saxons were of Germanic stock and most were illiterate. Hence, the giving of a verbal oath to bind themselves was important to their culture and such a practice (likely) derived from the Frankish kingdoms which occupied, roughly, the area occupied by France and Germany - under the Merovingian (c. 450-751 AD) and Carolingian (751-987 AD) kings. ${ }^{26}$ The moral and religious sacredness of the oath in Anglo-Saxon times was re-inforced by the Catholic church, whose clerics, being literate, helped draft the Anglo-Saxons dooms (legislation). ${ }^{27}$ Not only did Anglo-Saxon kings give a coronation oath since - at least, the time of king Edgar (959-75 AD, see 17) - but oaths were integral to many aspects of Anglo-Saxon daily life. ${ }^{28}$ Thus, Stephenson and Marcham, Sources of English Constitutional History, cite the following Anglo-Saxon oaths: ${ }^{29}$

- $\quad$ Oath of Fealty. 'By the Lord before whom this holy thing is holy [i.e. the altar, Bible or a relic], I will to [ ] be faithful and true, loving all that he loves and shunning all that he shuns, according to the law of God and the custom of the world; and never by will or by force, in word or in deed, will I do anything that is hateful to him; on condition that he will hold me as I deserve and will furnish all that was agreed between us when I bowed myself before him and submitted to his will.'

\footnotetext{
${ }^{22}$ In Babylonian, Anglo-Saxon and medieval times, contracting parties, sometimes, drank (or feasted) together to evidence the binding nature of their agreement (also, to entertain transaction witnesses, to thank them for their assistance as well as, likely, to help them recall the event in the future). This drink to seal the bargain (sometimes called, to 'wet' the bargain) was, often, accompanied by other acts such as a handshake or the giving of an oath.

${ }^{23}$ See e.g. The Compact NIV Study Bible (Hodder \& Stoughton, 1985), 2 Kings, ch 10, v 15 (said to have been written in the Babylonian exile period, c $550 \mathrm{BC}$ ), Jehu and Jehonadab give their hands in agreement to kill the family of Ahab. See also Ezra, ch 17, v 18 (thought to have been written c. 399 BC), the descendents of Jeshua and his brothers 'all gave their hands in pledge [promise]...'. This likely refers to the striking of hands, see also the Books of Proverbs, ch 6, v1; ch 11, v 15; ch 17 v 18; ch 22, v 26. See also McBain, n 17, pp 23-4.

${ }^{24}$ SA Cook, The Law of Moses and the Code of Hammurabi (Adam and Charles Black, 1903), p 209 refers to the 'striking of hands as an indication of agreement.' Tyler, $\mathrm{n} 9$, pp 104-5 maintained that, in the Bible, an oath was given between inferiors and that 'hand joining' (i.e. a handshake or handclasp) was given between equals.

${ }^{25}$ BS Philpotts, Kindred and Clan (1913), p 220 'Pledging by hand-clasp is a very definite feature of Scandinavian custom, and the English noun handsel [hand seal] is definitely a Scandinavian loan word. We cannot be certain that the Anglo-Saxon has not the same custom, but it is at least curious, in that case, that the only references to it in the post-Conquest [i.e. post-1066] borough customs are both in towns within the Danelaw.' See also McBain, n 17, p 180.

${ }^{26}$ For example, see A Rio, The Formularies of Angers and Marculf: Two Merovingian Legal Handbooks (2008). These formularies (that is, model legal documents) derive from the $6^{\text {th }}$ and $7^{\text {th }}$ centuries. See e.g. p 61 (accusation of the theft of a horse) "By this holy place [i.e. by this church] and all the divine things which take place here, and which are here offered plentifully to God: with respect to the charge that the man named C has brought against me, namely, that I stole his horse and kept it as a result of theft, I swear this, that I never stole his horse regarding which he has accused me, nor was I ever complicit in this theft ... etc.' The texts refer to the use of (usually, 12) oath helpers (compurgators) who confirmed (that is, verified the trustworthiness of) a man's oath.

${ }^{27}$ See generally, FL Attenborough (ed), The Laws of the Earliest English Kings (1922, rep 1963) and AJ Robertson, The Laws of the Kings of England from Edmund to Henry I (1925). The status of a priest was also high in Anglo-Saxon society. TFT Plucknett, TaswellLangmead's English Constitutional History ( $11^{\text {th }}$ ed, 1960), p 15 'the clergy, as a class, held a very high political and social status... Whilst all laymen, even of the highest rank, were bound to find a number of compurgators in addition to their own oath, in order to clear themselves from a charge, the simple oath of a priest was accepted as sufficient.' Ibid, p 23 'The accused might clear himself by his own oath strengthened by the oaths of certain compurgators, usually, twelve in number, and either his relatives or immediate neighbours, who testified to the trustworthiness of the person on whose behalf they came forward. The compurgators were in reality 'witnesses to character'.'

${ }^{28}$ e.g. see the frequent references to them in Anglo-Saxon dooms, see Attenborough, n 27, pp 240-1.

${ }^{29}$ C Stephenson \& FG Marcham (eds and translators), Sources of English Constitutional History (1937), p 25. See also: (a) RL Henry, Contracts in the Local Courts of Medieval England (1926), for Anglo-Saxon oaths in the contractual context; (b) FA Inderwick, The King's Peace (1895), pp 18-20; (c) W Holdsworth, A History of English Law (Sweet \& Maxwell, 2009 rep), vol 2, pp 105-8.
} 
- Oath of an Accuser. 'By the Lord before whom this holy thing is holy, I thus bring my charge with full folkright, ${ }^{30}$ without deceit and without malice, and without any guile whatsoever, that stolen from me was this property [ ], which I claim [and] which I seized in the possession of [ ].'

- Oath of the Accused. 'By the Lord...neither by counsel nor by deed had I knowledge of or part in this, that the property [ ] was carried off. On the contrary, I possess the property for this reason, that I lawfully inherited it...that [ ] having the lawful right to sell it, sold it to me...etc.'

- Oath of one seizing Property. 'By the Lord...I seize [this property], neither through hate or hostility, nor through unrighteous greed, and I know nothing truer than what my spokesman has said for me, and what I now myself state as truth, that [] was the thief of my property.'

- Oath in reply to such Seizure. 'By the Lord...I am guiltless, both in thought and in deed, of the accusation made against me by [ ].'

- Oath of an Oath-Helper (i.e. a compurgator or witness to character). 'By the Lord...the oath which [ ] has sworn is clean and without falsehood [i.e. true]. ${ }^{31}$

Thus, the oath was the primary mode of proof, for legal purposes, in Anglo-Saxon times ${ }^{32}$ - with more than one oath being required in various circumstances. ${ }^{33}$ Further, the religious nature of the oath was emphasised ('By the Lord') - meaning, may the Lord be my witness - which invocation, likely, was from the Bible. ${ }^{34}$ Anglo-Saxon oaths were also short, definitive in nature and in standard form - all as befits a society with a population almost wholly illiterate. As for the breach of an oath, the sanctions were (it seems) ecclesiastical ones, save where the Anglo-Saxon dooms (law) expressly provided otherwise. Thus, the law of king Ine of Wessex (689-726 AD) provided for the payment of compensation resulting from a false oath given when vouching to warranty in the case of livestock. ${ }^{35}$ And, the laws of king Aethelstan (925-39 AD) provided that:

if anyone swears a false oath [i.e. an untrue oath] and it becomes manifest he has done so, he shall never again have the right to swear an oath; and he shall not be buried in any consecrated burial ground when he dies, unless he has the testimony of the bishop, in whose diocese he is, that he has made such amends as his confessor has prescribed to him. ${ }^{36}$ (italics supplied)

By the time of king Canute (also called Cnut, 1016-35) this penalty was increased. At least, in the case of the breach of an oath sworn on the relics. Thus, a law of his (possibly, post-1027) provides: ${ }^{37}$

\footnotetext{
${ }^{30} \mathrm{~B}$ Thorpe, Ancient Laws and Institutes of England (1840)(Glossary, folc-riht) 'the original, unwritten, understood compact, by which every freeman enjoys his rights as a freeman. The common or customary law of the land.'

${ }^{31}$ For other standard, Anglo- Saxon, oaths in legal proceedings (which all had a rhythmical tone), see Thorpe, n 30, pp 76-8. The oath helper (unlike a modern juror, who swears to tell the truth, whatever it may be) swore to the truth of his principal's oath. The term 'compurgator' is a later, ecclesiastical term used as an synonym for an oath helper. See Pollock \& Maitland, n 4, vol 1, pp 39, fn 2 \& 140. Proof by oath helpers did not end until 1833 ( 3 \& 4 Will 4 c 42 s 13). Ibid, p 150. Oath helpers were, originally (probably) a man's kinsmen. See Pollock \& Maitland, n 4, vol 2, p 600. See generally, H Adams et al, Essays in Anglo-Saxon Law (1905), containing JL Laughlin, The Anglo-Saxon Legal Procedure, pp 193 -305.

${ }^{32}$ Pollock \& Maitland, n 4, vol 1, pp 39-40 'Oath was the primary mode of proof, an oath going not to the truth of specific fact, but to the justice of the claim or defence as a whole. The number of persons required to swear varied according to the nature of the case and the rank of the persons concerned. Inasmuch as the oath, if duly made, was conclusive, what we now call the burden of proof was rather a benefit than otherwise under ancient Germanic procedure...An accused person who failed in his oath, by not having the proper number of oath helpers prepared to swear, or who was already disqualified from clearing himself by oath, had to go to one of the forms of ordeal.'

${ }^{33}$ Ibid, p 40 'A 'fore-oath' distinct from the definitive oath of proof, was required of the party commencing a suit, unless the fact complained of was manifest...A defendant of...evil repute [i.e. of ill fame] might be driven by the fore-oath alone to the alternative of a three-fold oath or the ordeal.'

${ }^{34}$ Bible, n 23, Deuteronomy, ch 6, v 13 'Fear the lord your God, serve him only and take your oaths in his name.' Zephaniah, ch 1, v 5 'those who bow down and swear by the lord...'. (italics supplied). See also Tyler, n 9, p 108. Ancient Egyptians appear to have sworn oaths in the name of Pharaoh (who was treated as a god), hence 'by Pharaoh my lord.', see Mercer, n 9, p 37.

${ }^{35}$ Attenborough, n 27, p 47 'If a man is vouched to warranty for livestock [i.e. challenged to his title to livestock] and he has previously disowned the transaction and wishes again to disown it, the oath required of him shall be equal to the amount of the fine involved and the value of the stock. If he does not wish to disown the transaction [a second time], he shall pay double compensation for his false [untrue] oath.' See also Ibid, p 212 (Laws of King Edward, 900-25) 'If anyone neglects this [referring to certain obligations in detecting crimes] and breaks his oath and his pledge [promise], which the whole nation [community] has given he shall pay compensation as the written laws declare.' For the payment of compensation by forfeiting land for breaking an oath, see Ibid, p 232 (Laws of Ine and of Alfred).

${ }^{36}$ Attenborough, $\mathrm{n} 27$, pp 141-2. It continued 'And his confessor shall make known to the bishop within thirty days whether he has been willing to make amends. If he [the confessor] does not do so, he [the oath breaker] shall pay such compensation as the bishop is willing to allow him [to pay].'

${ }^{37}$ Robertson, n 27, p 143, king Canute's Proclamation of 1020, c. 14, 'For all the bishops declare that very severe amends must be made to God for the violation of oaths and pledges.' Cf. pp 85 (22(2)) \& 171 (19(1)(obligations of Christians). See generally, Ibid, pp 407-8.
} 
if anyone swears a false oath [i.e. an oath that is untrue] on the relics and is convicted, he shall lose his hand or half his wergild which shall be divided between the lord and the bishop. And henceforth he shall not be entitled to swear an oath, unless he makes amends to the best of his ability before God, and finds surety that ever afterwards he will desist from such [perjury]. ${ }^{38}$ (italics supplied)

It is also possible to summarise how the use of both the oath - and the seal - developed in Anglo-Saxon law from Scandinavian (Viking) and Germanic customs, viz.

- $\quad$ Oath. The oath is age old, prior to the Old Testament. However, the latter stressed the religious nature of the oath (the invocation of God). With the departure of the Roman administration from England in $410 \mathrm{AD}$, there were progressive incursions by Germanic tribes (the Saxons) into England and, from $866 \mathrm{AD}$, the Vikings (Scandinavians). Both recognised the concept of an oath (the invocation of a deity) which - with the Christianizing of the Anglo-Saxons - became a Christian deity. Generally, in giving an oath, the right hand would have been raised in prayer (e.g. Genesis 14:22: 'But Abram said to the king of Sodom 'I have raised my [right] hand to the lord, God most high, creator of heaven and earth');

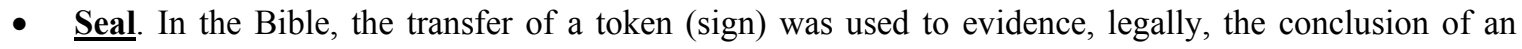
agreement (also called a contract or the striking of a bargain). For example, a shoe (as Abraham used when buying land as a burial land) or silver (in powder form, prior to coinage) or a handshake (likely, only between equals) or the giving of an oath (given by an inferior to a superior). In Roman times, instead, a gold ring was (often) transferred by one party to another to signify the conclusion of an agreement (the ring was returned on full payment, unless part of the purchase price). Or a scales was struck with a piece of copper (prior to coinage, and similar to the auctioneer's hammer). In the early Roman Catholic church, the gold ring was replaced with a wax seal on a document. However, since the Germans and Vikings were illiterate, to indicate that they had reached agreement on a matter, they gave a 'hand seal' instead - the 'seal' (token) being the shaking of another's hand (or clasp up to the elbow). An oath would have accompanied this. And, it would (likely) have been given without any handshake or handclasp in the case of a superior dealing with an inferior, such as in the case of an oath of fealty.

In conclusion, oath-giving was an integral part of Anglo-Saxon society and the primary means of legal proof (evidence). The simple form - and rthymic tone - of an oath was appropriate to an illiterate people.

\section{OATHS IN EARLY MEDIEVAL TIMES}

(a) Continued Importance of Oaths

Oaths remained an important part of English society after the Norman Conquest of $1066 .{ }^{39}$ For example:

- $\quad$ Oath of Fealty. An assembly (in Anglo-Saxon, gemot) was held on Salisbury Plain on 1 August 1086 attended by the witan ${ }^{40}$ and all the landowners of substance in England. Those assembled swore an oath of fealty to William the Conqueror (William I, 1066-87). ${ }^{41}$ Such an oath was not dis-similar to the oath given to king Edmund (921-46 AD) in c. 943, some 150 years earlier. ${ }^{42}$ Henry I (1100-35) also secured a similar oath on Salisbury Plain in $1116 ;^{43}$

\footnotetext{
${ }^{38}$ Ibid, p 195 (it may be noted that relics were, by this time, often contained within the altar). Cnut was Scandinavian (king of Denmark and, later, Norway). Thus, he may have moved to their harsher practice for breach of an oath. The loss of a hand (the right hand, the sword hand and hand for swearing an oath) would have been grievous. See also Pollock \& Maitland, n 4, vol 2, p 541.

${ }^{39}$ There were also new oaths. For example, a Frenchman appealed of a crime by an Englishman - if unwilling to submit to proof by means of a judgment or the duel - had to purge himself by giving an unbroken oath. See DM Stenton, English Justice between the Norman Conquest and the Great Charter 1066-1215 (1964), p 6.

${ }^{40}$ Thorpe, n 30, (Glossary, witenagemut), described it thus in Anglo-Saxon times, '[an assembly of] ealdormen, duces [leaders], earls, thanes, abbots, priests, and even deacons. In this assembly, laws, both secular and ecclesiastical, were promulgated and repealed, and charters of grants made by the king confirmed and ratified. Whether this assembly met by royal summons, or by usage at stated periods, is a point of doubt.'

${ }^{41}$ Plucknett, n 27, p 34. See also Robertson, n 27, p 239 '(Ten Articles of William I) 'we have decreed that all freemen shall affirm by covenant [promise] and oath, that, both in and out of England, they will be loyal to king William I [1066-87], and along with him uphold his lands and honour with the utmost loyalty, and defend them before him against his enemies.'

${ }^{42}$ Robertson, n 27, p 13 (Law of king Edmund) 'all shall swear in the name of the Lord, before whom the holy thing is holy [possibly, referring to an altar or a relic], that they will be faithful to king Edmund, even as it behoves a man to be faithful to his lord, without any dispute or dissension...'?

${ }^{43}$ Plucknett, n 27, p 127. In 1215, prior to Magna Carta, king John (1199-1216) ordered the sheriffs to administer the oath of allegiance and fealty to the freemen of every shire. Ibid, p 70 .
} 
- Oath of a Juror. In a case in 1127 to decide who had the right to a port and certain tolls, 12 jurors from Sandwich and 12 from Dover gave a juror's oath, ${ }^{44}$ swearing on the Bible (the gospels) as they would have done in Anglo-Saxon times.

Indeed, the form of the Anglo-Saxon oath - its simplicity, succinctness and religious nature - tended to change little over the centuries. For example, the oath of an Anglo-Saxon oath helper (also, called a compurgator - that is, who was one who swore to his belief in the truth of another's oath) was much the same in the $15^{\text {th }}$ century as it was in Anglo-Saxon times. ${ }^{45}$ The manner of swearing - on the Bible or on an altar (which tended to contain a relic $)^{46}$ - also, remained unchanged. ${ }^{47}$

\section{(b) Early Legal Texts on Oaths}

The earliest law book, Glanvill, Treatise on the Laws and Customs of the Realm of England (c. 1189), referred to the giving of oaths, post- Conquest, in various instances. ${ }^{48}$ So too, the other major legal text of that period, Bracton, On the Laws and Customs of England (c. 1250). ${ }^{49}$ Inter alia, it referred to the following:

- Oaths required in Civil Actions. Bracton referred to the form of oath sworn by a juror in various civil actions such as in the civil assizes (legal proceedings) of novel disseisin, darrein presentment, mortdancestor or assize utrum. Also, when warranting an essoin (i.e. when a party swore that he was detained from attending court by reason of illness); ${ }^{50}$

- Oaths of Homage \& Fealty. Bracton referred to the basic oaths of homage ${ }^{51}$ and of fealty, ${ }^{52}$ which oaths remained important throughout the medieval period; ${ }^{53}$

- Public Offices - Oaths. Bracton referred to the oath sworn by a judge when taking office; ${ }^{54}$

- Legal Proceedings. Bracton referred to the promissory oath of the 12 jurors in a plea of the crown (that is, in the case of a criminal offence) when the judges were on eyre (circuit). ${ }^{55}$ Also, to the oath of the 12

\footnotetext{
${ }^{44}$ Stenton, $\mathrm{n} 39$, pp 20, 120-1 'The first of them [i.e. the first of the jurors], Wulfwine son of Beornwine, standing in the midst of the multitude and holding in his hands the sacred book of the gospels [the Bible], spoke thus: 'I swear, the toll of the port of Sandwich, all the maritime customs on either side of the river from [ ] to [ ], and the ferryboat, belong to [ ], nor has anyone else any right there save them and their servants, as I have learned from my ancestors and seen and heard from my youth up to now, so help me God [sic me deus adiuuet] and these holy gospels.'

${ }^{45}$ Henry, $\mathrm{n} 29, \mathrm{p} 53$ 'The oaths of the defendants and of their compurgators were thus substantially the same from the tenth to the fifteenth century, inclusive'. See also Ibid, p 76.

${ }^{46}$ The need for all altars to contain relics was a requirement from the reign of Charlemagne (768-814 AD), Rio, n 26, p 24.

${ }^{47}$ Henry, n 29, p 53 'The usual manner of swearing was for the person to do so with his hand on the book, usually the gospels [Bible], and to kiss the book. The following exhortation by the judge to him who is about to give an oath is quoted from the Cinque Ports custumal: 'The judge shall exhort him or them that shall swear[,] to take the heed to themselves what danger it is to forswear [i.e. perjure] himself willingly, to forsake almighty God and their baptism and all this [his] good works and their part [place] in heaven and give themselves to the devil in hell.' (spelling modernised).

${ }^{48}$ GDG Hall (ed), Glanvill (Nelson, 1965), p 209 (Index, oaths). See also LJ Downer, Leges Henrici Primi (Laws of Henry I, Oxford, 1972). This text (written c.1113), p 111 'Anyone who commits perjury on the relics shall lose his hand or half his wergild...Anyone who gives false testimony shall not thereafter be permitted to bear testimony [i.e. be an oath giver]...'. Cf. Law of Canute, see text to $\mathrm{n} 38$. Wergeld (wer) was the price that a man's life was valued at according to his status, see Thorpe, $\mathrm{n} 30$ (glossary, wergild).

${ }^{49}$ Bracton, On the Laws and Customs of England (SE Thorne, ed, 1968, 4 vols).

${ }^{50}$ Ibid, passim

${ }^{51}$ Bracton, $\mathrm{n} 49$, vol 2, p 232 '(the tenant placing his hands between the hands of the lord) 'I become your man with respect to the tenement which I hold of you (or 'which I ought to hold of you') and I will bear you fealty in life and limb and earthly honour (according to some, but according to others, 'in body and goods and earthly honour') and I will bear you fealty against all men (or 'all mortal men,' according to some) saving the faith owed the lord king and his heirs'. This form of oath existed as early as 1113, see Downer, n 48, p 173.

${ }^{52}$ Ibid, 'Hear this, lord [ ], that I will bear you fealty in life and limb, in body, goods, and earthly honour, so help me God and these sacred [relics]'. See also Pollock \& Maitland, n 4, vol 1, p 298.

${ }^{53}$ For oaths of fealty given by the Scots in 1291 and 1296 to Edward I (1272-1307), see M Powicke, The Thirteenth Century 1216-1307 (2nd ed, 1962, rep 1986), pp 606, 615-6.

${ }^{54}$ Bracton, $\mathrm{n} 49$, vol 1, p 309 'The oath shall be this. Each [judge] will swear...that in the counties into which they are to travel they will do right justice to the best of their ability to rich and poor alike, and that they will observe the assize according to the articles set out...and that they will execute all that is right and just in matters pertaining to the crown of the lord king.' See also Pollock \& Maitland, n 4, vol 1, p 154. ${ }^{55}$ Ibid, p 329, the first of the jurors shall say: 'Hear this, ye justices, that I will speak the truth as to that on which you shall question me on the lord king's behalf, and I will faithfully do that which you shall command me on the lord king's behalf, and for nothing will I fail so to do to the utmost of my power, so help me God and these holy relics.' And after him each of the others, separately and individually, shall swear an oath in this form: 'The oath that A (that is the first juror) has here sworn I will for my part keep, so help me God [sic me deus adiuuet] and these holy relics.' For the oath of an outlaw as to his abjuring the realm (i.e. going into exile), Ibid, p 382. For the oath in the case of the duel, Ibid, pp 399-400.
} 
jurors in the case of a plea of the crown in a township. ${ }^{56}$ The oath of a juror was different from that of a witness, whose legal appearance only developed later. ${ }^{57}$ There were also oaths given by an appellor (i.e. one making an accusation against another of a crime) and an appellee. ${ }^{58}$

Bracton refers to the invocation 'So help me God' which was little different to the Anglo-Saxon one of 'By the Lord ${ }^{59}$ Both of these phrases comprise an invocation of God as a witness and both may have originated from the injunction in the Bible (the Book of Deuteronomy):

Fear the lord your God... and take your oaths in his name. ${ }^{60}$

\section{(c) Britton - Legal Description of an Oath}

A classic statement on the nature of the oath was given in a legal text by Britton in 1290:

An oath is an affirmation or denial of anything, whereby a person is charged upon peril of his soul to speak the truth; and it was provided on account of people difficult of belief that oaths should be taken upon the holy gospels of God for avoidance of idolatry. Oaths were instituted that men might thereby do good service; for by means of an oath many crimes are convicted and punished, and many a man does by an oath great good and great service to his neighbour. It was likewise provided that one should swear by God and not by his creatures, or his members, to avoid the sin of blasphemy, and that none should swear but with an intention of doing service by the oath, upon necessary and just occasions. An oath therefore is allowable when the conscience within agrees in every point with the lips, without alteration or abatement; and if there be any disagreement, it is perjury...perjury is a lie [a false statement] affirmed by oath. ${ }^{61}$

Britton noted that some oaths were promissory. These were of three kinds. However, breach of the same were not subject to legal sanction - save for oaths given in the legal context, where the crime of perjury was committed. ${ }^{62}$ However, prosecutions for perjury may have been limited to jurors giving false verdicts at assizes, as opposed to other inquests. ${ }^{63}$ Further, the law on perjury may not have been strictly enforced ${ }^{64}$ - despite the strong words of Glanvill (see (b) above) in c. $1189 .{ }^{65}$

\footnotetext{
${ }^{56}$ Ibid, p 405 'When the twelve jurors and the [jurors of] the four townships are present, those of the vills will take an oath first, each by himself or all together; lifting up their hands let them swear in these words... 'Hear this, ye justices, that we will speak the truth about what is asked of us on the king's behalf, nor will we for any reason fail to tell the truth, so help us God etc.'

${ }^{57}$ The witness was not the same as the oath helper (compurgator). His oath was an assertory one according to a set formula (an oath that he had been present when a certain event/act had occurred, i.e. an eye witness). See also Pollock \& Maitland, n 4, vol 1, p 140 \& vol 2, p 601. Quite when the witness came in as part of English legal procedure is not known, see Ibid, vol 2, p 628. See also Holdsworth, n 29, vol 9, p 179.

${ }^{58}$ Bracton, n 49, p 432 'Here this, O man, whom I hold by the hand and who callest thyself A by thy baptismal name, that I am not a thief nor thy confederate in theft (or 'robbery' and the like) nor did I steal with thee such a thing at such a place ('nor did we [together] commit such a robbery' or whatever it may be) nor did I have such an amount as my share, so help me God etc.' The appellor shall then swear affirmatively 'Then let the approver say: 'Hear this, o man, whom I hold by the hand and callest thyself B by thy baptismal name, that thou art a perjurer, and perjured in this wise, because thou art a thief and a confederate of mine in theft, because we stole together such a thing at such a place (or 'we together committed such a robbery' or did whatever it may be) and thou hadst so much as thy share thereof, so help me God etc.' For the formulation c. 1290, see Britton, n 61, pp 96-7.

${ }^{59} \mathrm{Cf}$. Tyler, n 9, p 59 'When they settled in the present phrase, 'So help me God', I cannot discover'. As to this, see $\mathrm{n} 44$ (it was certainly in use prior to 1127). Likely, the source of the expression is the Bible, see n 34 (swear by the lord). Also, Bible, n 23, Book of Psalms, ch 109, v 26 'Help me, O Lord my God.' For many other instances in the Bible where a person appeals to God for help, see EW Goodrick \& JR Kohlenberger III, The Strongest NIV Exhaustive Concordance (Zondervan, $2^{\text {nd }}$ ed, 1999)(help).

${ }^{60}$ Bible, n 23. See also ns $34 \& 86$.

${ }^{61}$ FM Nichols (trans) Britton (1290, John Byrne \& Co, 1901), pp 510-2. See also Fleta (c. 1290), Selden Society, vol 99, p 65 (bk 5, ch 21) 'An oath is an affirmation or denial of something, strengthened by swearing upon a sacred object...Of oaths some are affirmatory as regards the past or the present, some are promissory as regards the future. Perjury is a lie confirmed with an oath...'.

${ }^{62}$ Ibid, n 61, pp 502-3 'The first is where any one promises by an oath that he will do or assist in something which ought not to be done, as feloniously kill a man; and such an oath ought not to be kept. The second is where a person swears that he will do something which he may lawfully do, and this solemnly, but without necessity or reason, and in so doing he is guilty of sin. The third kind of swearing is that which proceeds from a levity in talking and from a bad habit; this kind of swearing is sinful, but less so than the former. But of these three kinds of oath we shall not speak in this chapter; for they are not subject to earthly attaint [i.e. to criminal process], nor is any oath except that of assertion which relates only to time past or present [Britton was referring to assertory (declaratory) oaths given in legal proceedings].' As to whether, apart from attaint, a person could be punished under the common law for perjury prior to the Perjury Act 1562, see W Hudson, $A$ Treatise of the Court of Star Chamber (ed. F Hargrave with intro by TG Barnes, Legal Classics, 1986), pp 72-82.

${ }^{63}$ Ibid, pp 278-9 (oath for an assize jury), 'When the parties have agreed upon the jury, then let the first juror, touching the holy gospels, swear after this manner 'Hear this, ye justices, that I will speak the truth of this assize...etc.'

${ }^{64}$ Pollock \& Maitland, n 4, vol 2, pp 541-2 'The main weight of the probative procedure of the king's courts was being thrown upon the oaths, not of the parties, nor of witnesses adduced by them, but of jurors. In most cases, however, even those jurors stood in no terror of a law against perjury, for the rule was established that if both the parties to the litigation had voluntarily 'put themselves' upon a jury [i.e.
} 


\section{OATHS IN LATER MEDIEVAL TIMES, FROM 1290}

In later medieval times (that is, post-1290) it is likely that the giving of an oath - and its importance - declined. Such was (likely) linked to an increase in literacy and to the development of writing as well as to a growth in population and a decline in religiosity.

\section{(a) Development of the Deed}

Putting legal matters in writing (in a carta, charter) developed, in the main, after the Norman Conquest 1066 with the Normans, also, bringing with them the use of the seal, adopting the Roman chancery practice of the Catholic church ${ }^{66}$ Writing - being more permanent and reliable evidence than an oral declaration - the English courts placed more credence on it and they recognised, from the late 13th century, the legal concept of a 'deed' (that is, a written document sealed by the maker to evidence his consent to the same). Likely, at first, deeds were accompanied by oaths. However, the latter soon dropped away and oaths were not a pre-requisite for a deed which legal concept - in time - adopted as legal pre-requisites: writing, sealing and delivery - pre-requisites which were to prevail until modern times. ${ }^{67}$

\section{(b) Changing Marketplace}

Verbal oaths would still have been used in the marketplace for asserting title to goods, warranting their condition etc. However, from the reign of Henry II (1100-35), there developed, in England, much foreign trade (and international markets) as well as an expansion in domestic trade. ${ }^{68}$

- Thus, giving an oath in a foreign language or in a dialect or with a foreigner (who may not have been religious or, even, a Christian) would have resulted in declining reliance on the efficacy of such an oath, as the time honoured Anglo-Saxon expressions may have given way to less certain ones;

- Further, in cosmopolitan London and other large English towns, transactions would have been conducted between persons who knew nothing of the moral integrity, or the religiosity, of each other unlike in small towns and villages where everyone knew each other's business and 'fame' (reputation);

- Besides, other evidence of being contractually bound developed - such as tallies and the use of tokens (including the more widespread use of coinage) ${ }^{69}$ - so that oral oaths and affirmations of any sort became supplementary.

Thus (likely) oaths - and the credence to be placed on them - tended to decline in the area of commerce. ${ }^{70}$ Further, in the courts, the rise of professional swearers (also called, common swearers or common compurgators) debased greatly the sanctity of the oath, such that it became a scandal. ${ }^{71}$ Further, the problem with the oath was

chosen a jury trial] neither of them could complain of the verdict. On the other hand, 'assizes' as distinct from 'juries', are the outcome not of consent but of ordinance. An assize therefore may be attainted, that is to say, the verdict of the twelve men can be brought before another set of twenty-four men and the twelve will be punished and their verdict reversed if the twenty-four disagree with them. The punishment for the false twelve looks upon paper a heavy punishment. They are to be imprisoned and lose their chattels; also they 'lose the law of the land', that is to say they cease to be 'oath worthy'. As a matter of fact we may sometimes see attainted jurors escaping with moderate fines. The law seems to have no procedure which directly strives to distinguish among untrue verdicts those which are sworn with a knowledge of their falsehood.' See also Bracton, n 49, vol 3, p 346.

${ }^{65}$ Glanvill, n 48, pp 35-6 (penalty for those who swear rashly [i.e. falsely] in the Grand Assize) "A penalty for those who swear rashly in this assize is ordained by, and appropriately set out in, the royal constitution. If the jurors are duly convicted in court of perjury, or confess to it in court, then they shall be deprived of all their chattels and movable goods which shall pass to the king, by whose great mercy their free tenements are excepted from this forfeiture. They shall, moreover, be cast into prison and be kept there for a year at least. In addition they shall lose their law for ever [i.e. cease to be oath worthy; that is, admitted to an oath] and thus rightly incur the lasting mark of infamy. This penalty is justly ordained, so that the fear of such punishment shall prevent all men from swearing a false oath in such a case.'

${ }^{66}$ See generally, GS McBain, Abolishing Deeds, Specialties and Seals - Parts 1 \& 2 (2006) 20(1) CLQ pp 15-54 \& 20(2) CLQ, pp 3-28.

${ }^{67}$ Ibid.

${ }^{68}$ See generally, GS McBain, The Strange Death if the Law Merchant (2016) International Law Research, vol 5, no 1, pp 32-151.

${ }^{69}$ See generally, McBain, n 17, pp 55-6.

${ }^{70}$ However, the guilds, the Crown and the courts still retained oaths for those entering into an official office, e.g. HT Riley, Liber Albus: The White Book of the City of London (1861), pp 265-76 (oaths of the mayor, sheriffs, aldermen, recorder, chamberlain, common counter [pleader], sarjeant-at arms, common clerk, serjeants of the mayor and chamber, constables, scavagers, bedels [beadles], those put under frankpledge, brokers, ale conners [i.e. ale tasters], under sheriffs and their clerks, sheriff's sarjeants, sheriffs' grooms). As to the White Book, in 1419, John Carpenter made a repertory (that is, a book of remembrances) of existing laws, observances, rights and franchises of the City of London which is generally referred to as the Liber Albus. This was translated by HT Riley in 1861.

${ }^{71}$ Pollock \& Maitland, n 4, vol 2, p 636, speaking of the decay of the trial by oath, 'In the king's court and the seigniorial courts the swearer [oath giver] was allowed to choose his own assistants - usually eleven or five - and the process fell into bad repute. The concentration of justice at Westminster did much to debase the wager of law [i.e. the giving of oaths by compurgators] by giving employment for a race of professional swearers.' See generally, Ibid, pp 634-6. Also, McBain, n 68, p 55, n 213. 
that it was only morally binding in most instances ${ }^{72}$ with the crime of perjury, also, being little enforced. The result was, as Maitland put it, 'our ancestors perjured themselves [i.e. lied on oath] with impunity'. ${ }^{73}$ Degeneration in oath giving was adverted to in an address to Henry VI (1421-71) by the prelates and clergy of the province of Canterbury, assembled in convocation at St Paul's Cathedral in London in 1439. They noted:

many folk that might get their living by occupation of lawful crafts and other true labours, cast up true business and rightful occupation, and intend [seek] in great part to get their living by bearing of false witness in inquests, and occupation of conspiracies. [this refers to people acting as common swearers]

And thus by boldness of perjury in such falsely procured and used indictments, the dread of God's doom is forgotten, the law of God's precepts is damnably contraried and broken, while the name of God in such wrongfully-used indictments is wittingly [knowingly] taken to false witness, and the faith of Christ waxeth slack in such forsworn jurors [i.e. perjurors], as though [if] the rightful judgment of God should not punish the sin of such perjury... ${ }^{74}$

\section{In conclusion, in later medieval times, there was a decline in the legal importance of oaths and reliance on} them.

\section{OATHS FROM THE $16^{\mathrm{TH}}$ CENTURY - 1868}

\section{(a) Misuse of Oaths}

In the $16^{\text {th }}$ century - indeed, until present times - the nature of the oath as a religious declaration remained as before. ${ }^{75}$ However, oaths (often) lost the brevity of Anglo-Saxon times, becoming more prolix, unwieldy and unclear. For example, the oath of office of a justice of the peace ('JP') in the county of Kent in the period 155396 provided:

Ye shall swear that, as [JP's] in the county of Kent, in all articles in the Queen's commission to you directed ye shall do equal right to the poor and to the rich after your cunning [knowledge], wit, and power, and after the laws and customs of the realm and the statutes thereof made; and ye shall not be of counsel with any quarrel hanging before you; and that ye shall hold your sessions after the form of statutes thereof made; and the issues, fines, and amercements that shall happen to be made, and all forfeitures which shall fall before you, ye shall cause to be entered without any concealment or embezzling and truly send them to the Queen's exchequer. Ye shall not let [i.e. give judgment] for gift or other cause, but well and truly ye shall do your office of [JP] in that behalf; and that you take nothing for your office of [JP] to be done, but of the Queen, and fees accustomed, and costs limited by the statute; and ye shall not direct nor cause to be directed any warrant by you to be made to the parties, but ye shall direct them to the bailiffs of the said county or other of the Queen's officers or ministers, or other indifferent [impartial] persons, to do execution thereof. So help you God and by the contents of this book [the Bible]. ${ }^{76}$

Also, oaths were being used to trap people into restrictive trade practices and other onerous obligations, ${ }^{77}$ including ones in which severe criminal penalties were imposed for breach. ${ }^{78}$ Thus, the Apprentices Act 1536 noted that members of various guilds (crafts) were being required, after their apprenticeship, to give oaths:

\footnotetext{
${ }^{72}$ For medieval ecclesiastical penances imposed on those who gave false oaths, see JT McNeill \& HM Gamer, Medieval Handbooks of Penance (1965), e.g. pp $91 \& 228$.

${ }^{73}$ Pollock \& Maitland, n 4, p 543.

${ }^{74}$ Quoted by Tyler, $\mathrm{n} 9$, pp 43-4 who said much the same at the time of his writing (in 1834), pp 52-3 'we are compelled to witness the dreadful extent to which perjury, direct palpable perjury, prevails among us from one end of the kingdom to another; and that not only in the ordinary and inferior offices of magisterial jurisdiction, but in the highest and most solemn tribunals of our country...Indeed one gentleman, very high in the profession, assured me, as a result of his own observation, that not one half of those who came before him to swear affidavits, seemed to feel that they were under the slightest religious obligation to speak the truth.'

${ }^{75} \mathrm{~J}$ Cowell, Law Dictionary (1708)(oath) 'is an affirmation or denial by any Christian of any thing lawful and honest before one or more that have authority to give the same, for the advancement of truth and right, calling almighty God to witness, that his testament is true.' $T$ Blount, A Law Dictionary and Glossary (1717) 'Oath (juramentum) is a calling almighty God to witness, that the testimony is true...Our ancestors did believe, that a man could not be so wicked to call God to witness any thing which was not true; but that if any one should be perjured [i.e. commit perjury], he must continually expect that God would be the revenger.' A MacBean, A Dictionary of the Bible (1779), 'Oath is a solemn appeal to God, as an all seeing witness and almighty avenger, if what we say is false.'

${ }^{76}$ Stephenson, n 29, pp 390-1 quoting W Lambard, Eirenarcha (1581). For the oaths of attorneys, jurors and court officials in the $16^{\text {th }}$ century and earlier, see J Baker, The Oxford History of the Laws of England, vol 6 (OUP, 1483-1558), p 956. See also E Coke, Institutes of the Laws of England (W Clarke \& Sons, London, last ed, 1824, which is cited in this article), vol 4 (see Index, referring to various oaths).

${ }^{77}$ Notorious for this was the use of the oath ex officio by the Court of High Commission [c. 1580-1640]. See DL Keir, The Constitutional History of Modern Britain since 1485 ( $9^{\text {th }}$ ed, 1969), p 131 'In the 1580's a Court of High Commission was set up, to exercise the supreme personal jurisdiction of the head of the Church, particularly in criminal matters; it was a spiritual Star Chamber, much hated for its
} 
that they... shall not set up, nor open any shop, house, nor cellar, nor occupy [the same] as [a] freeman without the assent and licence of the master, wardens or fellowship of their occupations [professions] upon pain of forfeiting their freedom or other like penalty; by reason whereof the said [ap]prentices and journeymen be put to as much or more charges thereby than they before time were put unto for the obtaining and entering of their freedom, to the great hurt and impoverishment of the said [ap]prentices and journeymen and other their friends. ${ }^{79}$

\section{(b) Religious Opposition to Oaths}

There was also increasing religious opposition from Quakers and dissenters - after the Reformation and the split from the Roman Catholic Church in the reign of Henry VIII (1509-47) - to the giving of an oath. Indeed, Catholic - and, later, Protestant - churches had an ambivalent attitude to oaths since they had, also, been open to widespread abuse in the time of Christ. Thus, many Jews in Christ's time had sought to avoid religious (moral) liability for breach of their oaths by making slight alterations to the verbal form of the oath. This, in the belief that they were, thereby, not morally bound by the same. ${ }^{80}$ Such Christ adverted to:

Woe to you blind guides ! You say, 'If anyone swears by the temple, it means nothing; but if anyone swears by the gold of the temple, he is bound by his oath. ${ }^{81}$ (italics supplied)

Christ also stated:

you have heard that it was said to the people long ago, 'Do not break your oath, but keep the oaths you have made to the Lord.' But I tell you, Do not swear at all; either by heaven, for it is God's throne; or by earth for it is his footstool; or by Jerusalem, for it is the city of the great king. And do not swear by your head, for you cannot make even one hair black or white. Simply let your 'yes' be 'yes' and your ' $n o$ ', ' $n o$ '; anything beyond this comes from the evil one. ${ }^{82}$

The result of this Biblical injunction was that - from the $16^{\text {th }}$ century in particular - various religious sects such as the Quakers, Anabaptists, Levellers and other dissenters strongly opposed the giving of an oath. ${ }^{83}$

\section{(c) New Forms of Oath}

In particular, in the $17^{\text {th }}$ century - in the religious and political ferment of those times - new oaths were invented, to which there was (invariably) strong opposition. For example, a canonical oath (often, called the et cetera oath) was required to be taken by all clergymen (priests), schoolmasters and university graduates by order of the Convocation of the Church of England (the 'CoE') in 1640. It went as follows:

I $[\mathrm{X}]$ do swear, that I do approve the doctrine and discipline, or government established in the Church of England, as containing all things necessary to salvation: and that I will not endeavour by myself, or

proceeding by oath ex officio, whereby a man could be driven to condemn himself under questioning.' For the repeal of this oath, see 16 Car $1 \mathrm{c} 11$, s 4 (1640, rep, Abolition of the Court of High Commission). Keir, n 77, p 92 'the oath ex officio by which the accused was compelled to answer incriminating interrogatories addressed to him by his judges.' See also Plucknett, n 27, pp 304-5. For the opposition of Sir Edward Coke to the sheriff's oath in 1625, see Rushworth, Historical Collections (1706), vol 1, p 127. See also, in 1627, in the time of Charles I (1623-49), the oath required from those who refused to lend money to the Crown (which required them to turn informer). Ibid, vol 1, pp xii \& 315 .

${ }^{78}$ Keir, n 77, p 106 'The Succession Act of 1536 annexed the penalties of treason to...refusing to take an oath to answer, or having taken it to refuse to answer questions relating to the Act... The Act extinguishing Roman authority in the same year made it treason in ecclesiastical or lay officials, tenants of the Crown, and persons taking orders, vows, or degrees, to refuse an oath upholding the royal supremacy and repudiating that of the pope. Under these statutes [John] Fisher [1469-1535, Bishop of Rochester] and [Thomas] More [1478-1535, former Lord Chancellor] had been the earliest victims.' Ibid, pp 65-6.

${ }^{79} 28$ Hen VIII c 5 (1536, rep) quoted by W Cunningham, The Growth of English Industry and Commerce (1910), p 512 who noted 'Such restrictions naturally resulted in the withdrawal of the journeymen to set up shops in suburbs or villages where the gild had no jurisdiction; and from this they were not precluded, in all probability, by the terms of their oath.'

${ }^{80}$ Tyler, n 9, p $21^{\text {' }}$ [the] folly of the Jews, who called upon creatures to witness their oaths in the hope at once of deceiving those to whom they swore, and still of not incurring perjury...'. Ibid, p 24 'the Jews, when they swore by heaven and earth, fancied they did not abuse God's name, because they did not utter it.' Ibid, p 113 'the distinction made by the Jews, between their judicial oaths, which were always sworn by the name of Jehovah, and their ordinary oaths, such as by the blood of Abel, by Jerusalem, heaven, earth, the Temple etc...the chief end aimed at was to be enabled to swear without exposing themselves to the terrors of the [Mosaic] law - to break their oath with impunity.'

${ }^{81}$ Bible, $\mathrm{n} 23$, Matthew, ch 23, v 16. See also James, ch 5, v 7 'Above all, my brothers, do not swear - not by heaven or by earth or by anything else. Let your 'yes' be yes, and your 'no', no, or you will be condemned.'

${ }^{82}$ Ibid, ch 5, v 37. The simplicity of Anglo-Saxon replies in a legal context ('yeah' (i.e. the latin, 'fiat') and 'nay' - including the triple 'nay'was, likely taken from the Bible).

${ }^{83}$ This was especially so in respect of groups like the Levellers. Well known was the instance of John Lilburne (1614-57) who, summoned before the Star Chamber in 1637, refused to take the prescribed oath on the basis that it was ex officio (i.e. not sanctioned by law). He was, thereafter, called 'Freeborn John'. The Star Chamber found him guilty of a high contempt. See Rushworth, n 77, vol 2, pp 344-5. 
any other, directly or indirectly to bring in any popish doctrine, contrary to that which is established: nor will I ever give my consent to alter the government of this Church [of England] by archbishops, bishops, deans and archdeacons etc as it stands now established, and as by right it ought to stand; nor yet ever to subject it to the usurpations and superstitions of the see of Rome: and that all these things I do plainly and sincerely acknowledge and swear, according to the plain and common sense and understanding of the same words, without any equivocation or mental evasion, or secret reservation whatsoever: and this I do heartily, willingly and truly, upon the faith of a Christian, so help me God in Jesus Christ. ${ }^{84}$

During the English civil war (1642-9), Parliament devised its own oaths. ${ }^{85}$ These, invariably, provoked strong opposition - even among those on its side fighting against the Crown (i.e. against Charles I, 1625-49).

\section{(d) Position of the CoE on Oaths}

Besides this, what Christ meant by prohibiting oaths was widely debated. Were his words to be read as a 'blanket' ban on oath giving or did they exclude, for example, oaths required by the State for legal purposes? It seems that the New Testament was not clear on this since St Paul did not appear to reject the giving of an oath. ${ }^{86}$ Further, Christ gave an oath to the high priest Caiaphas, when required to do so. ${ }^{87}$

- In an effort to diminish fractious debate, the CoE - in article 39 of its 39 Articles of 1562 - did not oppose the giving of an oath as such. ${ }^{88}$ Further, later CoE writers (and others) argued for this either on the basis that: (a) Christ did not prohibit oath giving outright but only certain forms of it; ${ }^{89}$ or (b) when oaths were compelled to be given by State, it was religiously acceptable to give the same, $;^{90}$

- However, such an analysis did not satisfy many and religious dis-satisfaction over the giving of an oath continued in some Protestant denominations as well as among philosophical thinkers (indeed, it still does). ${ }^{91}$

Further, it became asserted by legal writers and others than a person was not bound if the oath given was repugnant to the law of nature or unlawful. This, MacBean, Dictionary of the Bible (1779) summarised as follows:

\footnotetext{
${ }^{84}$ Rushworth, n 77, vol 3, p 168. Many priests refused to give this oath. Ibid, pp 168, 174, 176 \& 261. See also Keir, n 77, p 211 'These canons further deepened its unpopularity [i.e. that of the $\mathrm{CoE}$ ] by imposing the etcetera oath, in which the clergy...were bound to the defence of an ecclesiastical establishment uncertainly defined.' The Commons annulled the obligation to give this oath in 1641, see Rushworth, n 77, vol 4, p 95 who noted: 'It was likewise ordered [by the Commons] that the oath of canonical obedience should be laid aside'. See also Plucknett, n 27, p 392, n 89.

${ }^{85}$ Ibid, vol 5, p 564 'an oath was ordered [by Parliament] to be taken by all those who put themselves under the Parliament's protection, viz. that they will not adhere to, or assist the king in this war; and that their submission to the Parliament is voluntary, without the privity of the king or any of his officers, other than what the jurants had made known.' For this oath, see CH Firth \& RS Rait (eds), Acts and Ordinances of the Interregnum 1642-1660 (1911), vol 1, p 666. For the taking away of oaths of supremacy and allegiance, see Ibid, vol 2, p 1 (1648-9).

${ }^{86}$ Bible, n 23, Hebrews, ch 6, v 16 'Men swear by something greater than themselves, and the oath confirms what is said and puts an end to all argument.' See also Romans, ch 1, v 9 'God is my witness...' Also, 2 Corinthians ch 1, v 23 'I call God as my witness...'. EJ Bicknell \& HJ Carpenter, A Theological Introduction to the Thirty-Nine Articles of the Church of England (3 ${ }^{\text {rd }}$ ed, 1957), p 446, 'The solemn asseverations used from time to time by St Paul... may be considered a form of oath. They were needed because his converts had hardly yet reached the full Christian standard of morality. They do not violate any Christian principle, since they in no way imply a double standard of truthfulness.' He also accepted that 'the whole system of oaths is a makeshift. What is wanted is not a code of oaths but a spirit of truthfulness. Human selfishness and ingenuity will always endeavour to evade an oath, unless there is the right inward disposition.'

${ }^{87}$ Ibid, Matthew, ch 26 v 63 'The high priest said to him, 'I charge you under oath by the living God: Tell us if you are the Christ, the son of God. 'Yes, it is as you say, Jesus replied.' See also Tyler, n 9, pp 21-2.

${ }^{88}$ See 39 Articles of the Church of England, art 39 (of a Christian man's oath) 'As we confesseth that vain and rash swearing is forbidden Christian men by our Lord Jesus Christ, and James his Apostle: so we judge, that Christian religion doth not prohibit, but that a man may swear when the magistrate [i.e. the State] requireth, in a cause of faith and charity, so it be done according to the prophet's teaching, in justice, judgment and truth.' The reference to St James is to the quotation in n 81. See also C Hardwick, A History of the Articles of Religion (1859), p 327, for the latin version of 1563 .

${ }^{89}$ This logic may be seen in later texts, e.g. MacBean, $\mathrm{n} 75$, (oath) 'An oath in itself is in nothing unlawful, either as it is a religious act, or as God is called upon to witness, or as the [a] person who swears falsely, through abuse of the religion of an oath, subjects himself to the vengeance of heaven... The oaths forbidden ... refer only to the vicious practices of the Jews; otherwise St Paul would have acted against the command of Christ.'

${ }^{90}$ Bicknell, n 86, p 446 'the Christian, as a member of the State, will conform to the State's rule in matters that concern the State. To him...the oath will be superfluous, as he is equally bound to speak the truth at all times. He will, however, be content to follow the example of his master, who, though he gave the command 'swear not at all', yet was willing to be put on oath by Caiaphas and recognized the authority of the State (Mt 26, v 63)'. See also Tyler, n 9, pp 247-55.

${ }^{91} \mathrm{~J}$ Bentham, 'Swear not at All'. An Exposure of the Needlessness and Mischeviousness as well as Anti-Christianity of the Ceremony of an Oath (1817), especially, pp 71-5 (precepts of Christ against giving an oath).
} 
None can be bound by oath to whatever is repugnant to the law of nature; nor to keep any promise made contrary to it. Grotius [Hugo Grotius (1583-1645), the Dutch jurist] indeed says, that though nothing is due to the person to whom we swear, yet to God there is, in virtue of the oath; but it is not possible that God should approve base or vicious actions; and so far are we from doing what is acceptable to God, that we depart from our duty in doing it. As to [for] an oath procured by deceit and over-reaching, we are to enquire whether the thing promised is dishonest or no? If dishonest no oath can be binding... A robber extorts a promise from me by oath; am I bound to fulfil this promise? He has no right to my property, much less to extort it from me by oath...A person is guilty of perjury, who takes an oath in a sense different from that in which it is tendered: such simulation and dissimulation is called [a] mental reservation; which is contrary to the law of nature, because a violation of duty. ${ }^{92}$

\section{In conclusion, by the $17^{\text {th }}$ century, the issue of giving oaths was a source of strong contention. Coke sought to provide some legal clarity on oaths in his work.}

\section{COKE - NATURE OF THE OATH IN 1641}

The legal nature of the oath was summarised by Coke in the third volume of his Institutes of the Laws of England, published in 1641 (this was published posthumously, he died in 1628). Coke stated:

This word oath is derived of the Saxon word eoth...An oath is an affirmation or denial by any Christian of any thing lawful and honest, before one or more, that have authority to give [i.e. to administer] the same for advancement of truth and right, calling almighty God to witness, that his testimony is true ${ }^{93} \ldots$

So as an oath is so sacred, and so deeply concerns the consciences of Christian men, as the same cannot be ministered to any, unless the same be allowed by the common law, or by some act of Parliament; ${ }^{94}$ neither can any oath allowed by the common law or by Act of Parliament be altered, but by Act of Parliament. It is called a corporal oath, because he touches with his hand some part of the holy scripture... ${ }^{95}$

And oaths that have no warrant by law, are rather nova tormenta, quam sacramenta [new torments than scared oaths], and it is an high contempt to [ad]minister an oath without warrant of law, to be punished by fine and imprisonment [i.e. as a contempt]. And therefore commissioners (that set [i.e. are set up] by force of any commission that is not allowed by the common law, nor warranted by authority of Parliament) that [ad]minister any oath whatsoever, are guilty of an high contempt, and for the same are to be fined and imprisoned... ${ }^{96}$

It is unclear whether anyone prior to Coke had stated so plainly that to administer an oath when the same was not required by the common law or by legislation was a "high contempt. ${ }^{, 97}$ Elsewhere in his work - when

\footnotetext{
${ }^{92}$ MacBean, n 75 (oath). He also stated: 'Neither atheists nor epicureans, who deny, the former the being, the latter the providence of God, can have an oath administered, and be bound by... an oath, which declares the omniscience and vindictive justice of God.' (italics supplied) ${ }^{93}$ Coke also said, n 76, vol 4, p 278 'An oath ought to be accompanied with the fear of God, and service of God for advancement of truth....' ${ }^{94}$ Coke, n 76, vol 3, p 164. Coke continued 'The oath of the king's privy council, the justices, the sheriff etc was thought fit to be altered and enlarged, but that was done by authority of Parliament. For further proof whereof, and of the matters aforesaid, see the statutes here quoted, and it shall evidently appear that no old oath can be altered, or new oath raised without an Act of Parliament, or any oath ministered by any that have not allowance by the common law, or by an Act of Parliament. And to conclude this point, it was resolved in Parliament holden in anno 43 Eliz [43 Eliz, c 12, 1601] that the commissioners concerning policies of assurances [insurances] could not examine upon oath, because they had no warrant either by the common law, or by any Act of Parliament: and therefore it was enacted at that Parliament, that it should be lawful for the said commissioners to examine upon oath any witness etc. At this Parliament I attended, being then attorney general.'

${ }^{95}$ See also Tyler, n 9, pp 309-15.

${ }^{96}$ Coke, n 76, vol 3, pp 164-5. Tyler, n 9, p 69 (in 1834) thought that such a punishment 'seems to have fallen into desuetude'. As to the prevalence of oaths, J Selden, Table Talk (1686), para 94 'Now oaths are so frequent, they should be taken like pills, swallowed whole; if you chew them you will find them bitter; if you think what you swear, 'twill hardly go down.'

${ }^{97}$ For later statements of similar ilk, see JWC Turner, Russell on Crime (12 ${ }^{\text {th }}$ ed, 1964), vol 1, pp 233-4. Also, the Statutory Declarations Act 1835 , s 13 'It shall not be lawful for any [JP] or other person to administer, or cause or allow to be administered, or to receive or cause or allow to be received, any oath, affidavit or solemn affirmation touching any matter or thing whereof such [JP] or other person hath no jurisdiction or cognizance by some statute in force at the time being: provided always, that nothing herein contained shall be construed to extend to any oath, affidavit or solemn affirmation before any [JP] in any matter or thing touching the preservation of the peace, or the prosecution, trial or punishment of offences, or touching any proceedings before either of the Houses of Parliament, or any committee thereof respectively, nor to any oath, affidavit, or affirmation which may be required by the laws of any foreign country to give validity to instruments in writing designed to be used in such foreign countries respectively.' Ibid, pp 233-4. A JP contravening this section would be guilty of a misdemeanour, it seems. However, such a category no longer applies and it is dubious whether this s 13 is of use today. See also HW Woolrych, The Criminal Law (1862), p 933.
} 
analysing the Statute of Westminster the Second (1285), c 47 and discussing the oath of office to be taken by conservators of the Humber and other rivers - Coke stated:

A new oath cannot be imposed upon any judge, commissioner, or any other subject without authority of Parliament...but the giving of every oath must be warranted by Act of Parliament, or by the common law time out of mind. ${ }^{98}$

Coke also noted that the breach of an oath (that is, giving a false (untrue) oath) did not comprise the crime of perjury at common law - save in the case of an oath given in judicial proceedings:

For though an oath be given by him that has lawful authority, and the same is broken, yet if it be not in a judicial proceeding, it is not perjury ${ }^{99}$ punishable either by the common law, or by this Act, because they are general and extra-judicial, but serve for aggravation of the offence, as general oaths given to officers or ministers of justice, citizens, burgesses, or the like, or for the breach of an oath of fealty or allegiance etc they shall not be charged in any court judicial for the breach of them afterwards. As if [i.e. when] an officer commit extortion, he is in truth perjured, because it is against his general oath: and when he is charged with extortion, the breach of his oath may serve for aggravation. ${ }^{100}$ (italics supplied)

The 'Act', Coke was referring to was the first legislation on the crime of perjury, the Perjury Act 1562 (repealed in 1911).

\section{BLACKSTONE \& BURN - OATHS IN THE $18^{\text {th }} \& 19^{\text {th }}$ CENTURIES}

\section{(a) Book of Oaths (1715)}

A useful text on oaths - indicating who gave them and their form - is Garnet, Book of Oaths (1715). A list of the oaths Garnet refers to is attached to the end of this article. It may be noted that few of the offices and the courts to which the oath applied in 1715 still exist today. Further, by 1715, most promissory oaths (cf. those in legal proceedings which tend to be declaratory) could be categorised into just 2 categories:

(a) oaths of allegiance;

(b) oaths of fealty - later to be called oaths of fidelity and then official oaths (in the 1868 Act).

\section{(b) Blackstone on Oaths: 1765-9}

Blackstone, in his Commentaries on the Laws of England (1765-9), said little on the nature of oaths. However, in respect of perjury (in which he followed the definition of Coke) he stated:

The law takes no notice of any perjury but such as is committed in some court of justice, having power to administer an oath; or before some magistrate or proper officer, invested with a similar authority, in some proceedings relative to a civil suit or a criminal prosecution: for it esteems all other oaths unnecessary at least, and therefore will not pursue breach of them... ${ }^{101}$

\section{(c) Oaths Act 1775, s 1}

This section is mentioned since it is still extant. It clarifies that JP's may administer statutorily required oaths and affirmations. Thus, s 1 (in all cases where penalties etc are directed to be levied under Acts, justices are empowered to administer oaths etc for levying such penalties etc), states:

In all cases where any penalty is directed to be levied or distress to be made, by any Act of Parliament now in force or hereafter to be made, it shall and may be lawful for any [JP or JP's] acting under the authority of such Acts respectively, and he and they is and are hereby authorised and impowered to

\footnotetext{
${ }^{98}$ Coke, n 76, vol 2, p 478. When referring 'the common law time out of mind' he was likely referring to oaths - such as those of homage, fealty and allegiance (none of the breach of which Coke thought was punishable, per se, at law). Coke also noted that 'The oath of the [privy] counsellors, judges, sheriffs, under-sheriffs, escheators, attorneys, mayors, and bailiffs are established by Act of Parliament'. See also R Burn, The Justice of the Peace and Parish Officer (23 ${ }^{\text {rd }}$ ed, 1820), vol 3, pp 529-30 referring to Coke on this.

${ }^{99}$ Ibid, vol 3, p 164. Coke defined perjury as 'a crime committed, when a lawful oath is ministered by any that has authority, to any person, in any judicial proceeding, who swears absolutely, and falsely in a matter material to the issue, or cause in question, by their own act, or by the subornation of others.'

${ }^{100}$ Ibid, p 165. The Act referred to was the Perjury Act 1562 (5 Eliz c 9, rep 1911).

${ }^{101}$ W Blackstone, Commentaries on the Laws of England (1765-9), vol 3, p 165. He continued 'The perjury must also be wilful, positive, and absolute; not upon surprise, or the like: it also must be in some point material to the question in dispute; for if it only be in some trifling collateral circumstance, to which no regard is paid, it is no more penal than in the voluntary extrajudicial oath, as constitutes perjury in the principal.' Blackstone also noted the repeal of any statutory requirement to take an oath ex officio (vol 1, pp 101, 447 and see $\mathrm{n} 77$ ). And that, under certain Acts (now repealed), failure to take an oath, when required by them, was punishable as the crime of (or incurring the penalty of) praemunire (vol 4, pp 115-6, see also p 124). However, praemunire facias was abolished by the Criminal Law Act 1967.
} 
administer an oath or oaths, affirmation or affirmations, to any person or persons, for the purpose levying such penalties or making such distresses respectively. In this Act reference to making a distress include references to using the procedure in Schedule 12 to the Tribunals, Courts and Enforcement Act 1007 (taking control of goods) to recover a sum. ${ }^{102}$

\section{(d) Oath as a Religious Declaration: Caselaw in 1786}

A case in 1786 ( $R v$ White) emphasised the religious nature of an oath. In a trial for horse stealing a witness said that he had heard that there was a God and he believed those who told lies would come to the gallows. However, the witness acknowledged that he had never learned the catechism. Also, that he was altogether ignorant of: the obligations of an oath, a future state of reward and punishment, the existence of another world or what became of wicked people after death. The case report indicated that:

The court rejected him, as being incompetent to be sworn; for that an oath is a religious asseveration, by which a person renounces the mercy, and imprecates the vengeance of heaven, if he do not speak the truth; and therefore a person who has no idea of the sanction which the appeal to heaven creates, ought not to be sworn as a witness in any court of justice. ${ }^{103}$

\section{(e) Burn - Text on Justice of the Peace (1820)}

The standard legal text for JP's - Burn, The Justice of the Peace and Parish Officer (1820 ed) ${ }^{104}$ - stated:

An oath is a solemn asseveration made as strong and binding as possible, in order to beget faith and confidence in others, as to the certainly of what is affirmed. When men swear, nothing can make their asseveration so strong and binding, as the invocation of God to be their witness or avenger. ${ }^{105}$

Burn also referred to various statutory oaths current in 1820 , the:

- $\quad$ oath of allegiance (a military oath); ${ }^{106}$

- $\quad$ oath of supremacy (which came in at the Reformation, when papal authority was abolished); ${ }^{107}$

- $\quad$ oath of adjuration (abjuring the descendents of James II (1685-8) who abdicated); ${ }^{108}$

- declaration against transubstantiation (rejecting Catholic doctrine $r e$ the sacrament); ${ }^{109}$

- declaration against popery. ${ }^{110}$

These oaths (apart from that of allegiance) no longer exist. ${ }^{111}$

\footnotetext{
${ }^{102}$ Distress at common law has been abolished. Thus, reference to sch 12 only is pertinent.

${ }^{103} R v$ White (1786) 1 Leach 430-1. For the position of non-Christians giving oaths, see Holdsworth, $\mathrm{n} 29$, vol 9, pp 190-1.

${ }^{104}$ Burn, n 98, pp 526-42.

${ }^{105}$ Burn cited Deuteronomy, Bible, n 23, ch 1, v 34 'When the Lord heard what you said, he was angry and solemnly swore: 'Not a man of this evil generation shall see the good land I swore to give your forefathers...'.

${ }^{106}$ Burn, n 98, p 532 referred to 1 Geo 1 st 2 c 13 (1715, rep 1872). The oath of allegiance in the Act, s 2, was: 'I [X] do sincerely promise and swear, that I will be faithful and bear true allegiance to his majesty king George: so help me God.'

${ }^{107}$ Burn referred to the Act of 1715 referred to in $\mathrm{n} 106$ above. The oath of supremacy in the Act, s 2, was: 'I [X] do swear, that I do from heart abhor, detest and abjure, as impious and heretical, that damnable doctrine and position that princes excommunicated or deprived by the pope or any authority of the see of Rome may be deposed or murdered by their subjects or any other whatsoever. And I do declare that no foreign prince, person, prelate, state or potentate, has, or ought to have any jurisdiction, power, superiority, pre-eminence or authority, ecclesiastical or spiritual, within this realm: so help me God.' (spelling modernised). For the Act of Supremacy 1559, s 9 containing the original form of the oath of supremacy (which remained until the Glorious Revolution 1688, when a new form was enacted in the Bill of Rights 1688, 1 Will \& Mary, sess 2, c 2, s 3) see Plucknett, n 27, p 290, n 4 who noted 'All beneficed ecclesiastics, and all judges, justices, mayors, and other laymen holding office under the Crown, were required to take the oath of supremacy and allegiance, on pain of forfeiting their benefices or offices.'

${ }^{108}$ Burn, n 98, p 533 referring to 6 G 3 c 53 (1766, rep). Burn noted 'The oath of abjuration came in after the [Glorious] revolution [of 1688]; received some alterations in the first year of Queen Anne [1702]; and again in the first year of king George the first [1714]; and finally in the sixth year of king George the third [1766].' See also Condren, n 15, p 249.

${ }^{109}$ Ibid, p 534, referring to $25 \mathrm{Ch} 2$ c 2, s 9 (Test Act 1673, rep 1863). The declaration was: 'I [X] do declare, that I do believe that there is not any transubstantiation in the sacrament of the Lord's supper [i.e. holy communion] or in the elements of bread and wine, at or after the consecration thereof by any person whatsoever.' See also Repeal of Corporation and Test Acts 1828 (9 Geo Iv, c 14).

${ }^{110}$ Ibid, p 534 referring to $30 \mathrm{Ch} 2$ st 2 c 1 (Test Act 1678 (also, called the Second Test Act), rep 1866).

${ }^{111}$ Burn, p 538 also referred to the Unlawful Oaths Act 1797 (37 G 3 c 123, rep 1981). It stated, inter alia, "Whereas divers wicked and evil-disposed persons have of late attempted to seduce persons serving in his majesty's forces by sea and land, and others of his Majesty's subjects, from their duty and allegiance to his Majesty, and to incite them to acts of mutiny and sedition....and have endeavoured to give effect to their wicked and traitorous proceedings, by imposing upon the persons whom they have attempted to seduce the pretended obligation of oaths unlawfully administered...any person... who shall, in any manner or form whatsoever, administer, or cause to be administered...any oath or engagement [promise], purporting or intended to bind the person...to engage in any mutinous or seditious
} 


\section{(f) Statutory Declarations Act 1835 \& Oaths Act 1838}

Given the increasing uncertainty as to when oaths were legally required, who should give them and what their form was, various Victorian Acts attempted piecemeal reform. Thus, the Statutory Declarations Act 1835 enabled many institutions such as the Treasury, Oxford and Cambridge colleges and other corporate bodies to change oaths they required into declarations. However, this was voluntary. Sections of this Act, which are still extant, dealt (and deal) with the following:

- The Treasury could change their oaths into declarations; ${ }^{112}$

- Oaths and declarations made in courts of justice were preserved; ${ }^{113}$

- Oxbridge colleges (and all other corporate bodies) could change their oaths into declarations; ${ }^{114}$

- The Bank of England could employ declarations instead of oaths on stock transfers; ${ }^{115}$

- JP's were not to administer oaths if not permitted legislatively; ${ }^{116}$

- A written declaration was sufficient proof of the execution of a will; $;{ }^{117}$

- Suits (i.e. legal proceedings) brought on behalf of the sovereign could be proved by means of a declaration; ${ }^{118}$

- A voluntary declaration to a JP could be in a standard form. ${ }^{119}$

purpose, or to disturb the public peace; or to be of any association, society or confederacy, formed for any such purpose...etc [guilty of felony].' See also Unlawful Oaths Act 1812 (rep)(punishing the administering and taking of unlawful oaths). For these see also Holdsworth, n 29, vol 13, pp 168, 173 \& 203 and SF Harris, Principles and Practice of the Criminal Law (1943), pp 111-3.

${ }^{112} \mathrm{~S} 2$ (Lords of the Treasury empowered to substitute a declaration in lieu of an oath, \&c. in certain cases). ' In any case where by any Act or Acts made or to be made relating to the revenues of custom or excise, ...the office of stamps and taxes,...the war office, the army pay office, the office of the treasurer of the navy, ....or the ordnance, his Majesty's Treasury, Chelsea Hospital, Greenwich Hospital, the Board of Trade, or any of the offices of his Majesty's principal secretaries of state, the India board, the office for auditing the public accounts, the national debt office, or any office under the control, direction, or superintendence of the Treasury, or by any official regulation in any department, any oath, solemn affirmation, or affidavit might, but for the passing of this Act, be required to be taken or made by any person on the doing of any act, matter, or thing, or for the purpose of verifying any book, entry, or return or for any other purpose whatsoever, it shall be lawful for the Treasury, if they shall so think fit, by writing under their hands and seals, to substitute a declaration to the same effect as the oath, solemn affirmation, or affidavit, which might but for the passing of this Act be required to be taken or made; and the person who might under the Act or Acts imposing the same be required to take or make such oath, solemn affirmation, or affidavit, shall, in the presence of the commissioners, collector, other officer or person empowered by such Act or Acts to administer such oath, solemn affirmation, or affidavit, make and subscribe such declaration; and every such commissioner, collector, other officer or person, is hereby empowered and required to administer the same accordingly.' See also ss 3 (publication of declaration) \& 4 (no oath to be administered in lieu where a declaration is given) .

${ }^{113}$ Ibid, s 7 (oaths in courts of justice etc still to be taken) '...nothing in this Act shall extend or apply to any oath, solemn affirmation, or affidavit, which now is or hereafter may be made or taken, or be required to be made or taken, in any judicial proceeding in any court of justice, or in any proceeding for or by way of summary conviction before any [JP or JP's]; but all such oaths, affirmations, and affidavits shall continue to be required, and be administered, taken, and made, as well and in the same manner as if this Act had not been passed.' This proviso seems to now be obsolete.

${ }^{114}$ Ibid, s 8 (Universities of Oxford and Cambridge, and other bodies, may substitute a declaration into that of an oath) 'It shall be lawful for the universities of Oxford and Cambridge, and for all other bodies corporate and politic, and for all bodies now by law or statute or by any valid usage authorised to administer or receive any oath, solemn affirmation, or affidavit, to make statutes, byelaws, or orders authorizing and directing the substitution of a declaration in lieu of any oath, solemn affirmation, or affidavit now required to be taken or made: provided always that [such] be otherwise duly made and passed according to the charter, laws, or regulations of the particular university, other body corporate and politic, or other body so authorised as aforesaid.'

${ }^{115} \mathrm{Ibid}, \mathrm{s} 14$ (declaration substituted for oaths and affidavits required by the Bank of England on the transfer of stock) 'In any case in which it has been the usual practice of the Bank of England to receive affidavits on oath to prove the death of any proprietor of any stocks or funds transferable there, or to identify the person of any such proprietor, or to remove any other impediment to the transfer of any such stock or funds, or relating to the loss, mutilation, of defacement of any bank note...no such oath or affidavit shall in future be required to be taken or made, but in lieu thereof the person who might have been required to take or make such oath or affidavit shall make and subscribe a declaration to the same effect as such oath or affidavit.'

${ }^{116}$ Ibid, s 13, see n 97

${ }^{117} \mathrm{Ibid}, \mathrm{s} 16$ (declaration in writing sufficient to prove execution of any will, codicil etc). 'It shall and may be lawful to and for any attesting witness to the execution of any will or codicil, deed or instrument in writing, and to and for any other competent person, to verify and prove the signing, sealing, publication, or delivery of any such will, codicil, deed, or instrument in writing, by such declaration in writing made as aforesaid; and every such justice, notary, or other officer shall be and is hereby authorised and empowered to administer or receive such declaration.' Section 15 refers to legislation now repealed.

${ }^{118} \mathrm{Ibid}, \mathrm{s} 17$ (suits on behalf of his Majesty to be proved by declaration) 'In all suits now depending or hereafter to be brought in any court of law by or on behalf of [HM], in any of [HM's] territories, plantations, colonies, possessions, or dependencies, for or relating to any debt or account, [HM] shall and may prove his debts and examine his witness or witnesses by declaration, in like manner as any subject or subjects is or are empowered or may by this present Act.' 
For its part, the Oaths Act 1838 (now repealed) dealt with the legal effect when an oath giver failed to use the prescribed form. ${ }^{120}$ It provided:

in all cases in which an oath may lawfully be and shall have been administered to any person, either as a juryman or a witness, or a deponent in any proceeding, civil or criminal, in any court of law or equity in the [UK], or on appointment to any office or employment, or on any occasion whatever, such person is bound by the oath administered, provided the same shall have been administered in such form and with such ceremonies as such person may declare to be binding; and every such person in case of wilful false swearing may be convicted of the crime of perjury in the same manner as is if the oath had been administered in the form and with the ceremonies most commonly adopted. (italics supplied)

(g) Later Victorian Legislation on Oaths: 1851-71

Reference may also be made to the following Victorian legislation which is still extant:

- Evidence Act 1851, s 16 (every court, judge, JP, officer, commissioner of oaths, arbitrator, or other person having by law, or by consent of parties, authority to hear, receive and examine evidence, is empowered to administer an oath to all such witnesses as are legally called before them respectively);

- Parliamentary Oaths Act 1866 (deals with oaths required of peers and MP's, see 24);

- Parliamentary Witnesses Act 1871 (deals with oaths required of parliamentary witnesses). ${ }^{121}$

In conclusion, the legal nature of an oath did not change in the $17^{\text {th }}$ and $18^{\text {th }}$ centuries. However, many unsatisfactory oaths were engendered. Further, reform of the law was piecemeal and it did not get to the heart of matter - which was whether oaths were needed or whether statutory declarations would be better.

\section{OATHS COMMISSION 1867}

(a) 1867 Report

By later Victorian times, the legal situation as to oaths was still confused. Especially, as to what oaths were legally required and their form. Thus, an Oaths Commission was appointed (indeed, there were two). The royal patent for the Commission in 1866 stated:

We have deemed it expedient that a Commission should issue to inquire what oaths, affirmations and declarations are required to be taken or made by any of our subjects in the [UK], other than those to be taken or made by members of either House of Parliament, or by prelates or clergy of the established church, or by any person examined as a witness in any court of justice, or in any criminal or other proceeding before justices or otherwise of a judicial nature; and to report their opinion whether any and which of such oaths, affirmations, and declarations may be dispensed with, and whether any or what alteration may be made in the terms of such as it may be necessary to retain. ${ }^{122}$

The Report of the Oaths Commission (the '1867 Report') is useful to indicate the position as to oaths, affirmations and declarations existing in later Victorian times. It is, also, the best starting point to consider what should be the legal position today. The background to the Report was not only that the legal situation as to the nature - and giving - of oaths had become confused. There were, also, a growing number of Victorians who were atheist, agnostic or of faiths other than that of the Christian religion. Further, in some cases, there were reservations by various persons in respect of giving any oath to the Crown (in Ireland, this was against a background of many Irish advocating the independence of Ireland - with, or without, the Queen as sovereign). The 1867 Report referred to a great volume of oaths being given on a daily basis. Although, it did not analyse the legality of these, many would seem not to have been authorised by the common law (that is, recognised by

\footnotetext{
${ }^{119} \mathrm{Ibid}, \mathrm{s} 18$ (voluntary declaration in the form in the schedule may be taken) 'It shall and may be lawful for any [JP], notary public, or other officer now by law authorised to administer an oath, to take and receive the declaration of any person voluntarily making the same before him in the schedule to this Act annexed.' The declaration in the schedule was: 'I $[\mathrm{X}]$ do solemnly and sincerely declare, that and I make this solemn declaration conscientiously believing the same to be true, and by virtue of the provisions of an Act made and passed in the year of the reign of his present Majesty, intitled 'An Act (here insert the title of this Act).' Section 19 dealt with fees.

${ }^{120}$ Interesting, this reflected older Jewish practice, see ns $80 \& 82$.

${ }^{121}$ Section 1 (examination of witnesses on oath by the House of Commons and committees of the House) 'The House of Commons may administer an oath to the witnesses examined at the bar of the said House. Any committee of the House of Commons may administer an oath to the witnesses examined before such committee. Any oath...under this Act may be administered by the Speaker of the House of Commons, or by such person or persons as may from time to time be appointed for that purpose either by him or by any Standing Order or other Order of the said House.' Section 3 (as to additional power or privilege of House of Commons).' Nothing in this Act shall be held to confer any additional or further power or privilege on the Commons House of Parliament with reference to impeachment or other criminal jurisdiction or otherwise howsoever than is herein expressly enacted) This s 3 appears obsolete.

${ }^{122}$ Report of the Oaths Commission (Eyre \& Spottiswoode, 1867). The terms of the two Commissions were the same, pp iii \& vi.
} 
the common law courts or by legislation. Therefore, following Coke (see 8), in strict legal terms, they were unlawful. Many oaths being utilised were, also, voluminous and couched in archaic language - some of which wording did not make much sense or which was impossible of fulfilment. In the 1867 Report, the Commission stated:

We find that, although recent legislation has abolished certain oaths and converted others into declarations, ${ }^{123}$ the number of oaths still required to be taken is exceedingly large. Of these, many appear to us unnecessary, some even mischievous. We believe that every requirement of an unnecessary oath tends to detract from the solemnity of necessary oaths. ${ }^{124}$ Further, we conceive that to maintain the solemnity of oaths the terms of every oath should be precise and exact; and that where altered circumstances have rendered some of the engagements needless or impossible of fulfilment the oath ought, if it be retained, to be cleared of these obsolete or impossible engagements. ${ }^{125}$

The Commission did not consider oaths given in a judicial (court) context. In respect of the others, the Commission categorised them into:

- $\quad$ oaths of allegiance; and

- $\quad$ oaths of fidelity to an office.

The Commission believed that the oath of allegiance should be retained in the case of all great national offices of state. ${ }^{126}$ Also, by army recruits - to 'quicken and maintain their loyalty. ${ }^{127}$ In the case of the oaths of fidelity (where a person swore they would faithfully perform some public office), the Commission believed that it should be retained for judges of the superior courts and for jurymen only and that all other oaths should be abolished or changed into declarations. The Commission also indicated that oaths (or declarations) framed to exclude those of a particular religious faith from particular offices (mainly, Catholics and Jews) should be abolished and that any exclusion should now be made in the form of legislation rather than, indirectly, by oath or declaration. $^{128}$

\section{(b) Oaths Commission - Dissenters}

There were four dissenting opinions to the 1867 Report. Three of these are of little significance today since they fell away with the 1868 Act. ${ }^{129}$ However, the dissent of five members to the Report are, historically, much more interesting. They concluded:

A careful examination of the oaths referred to this Commission has led us to the conclusion that by far the greater number ought to be wholly abolished; and the rest changed into some convenient and distinct forms of declaration. ${ }^{130}$

In respect of oaths of allegiance, in particular, the dissentients noted:

\footnotetext{
${ }^{123}$ For example, in 1833, Quakers, Moravians and separatists were enabled by statute (3 \& 4 Will 4, cc 49, 82 (1833, rep)) to substitute an affirmation for an oath. See also 1 \& 2 Vict c 77 (1838, rep). See also Plucknett, n 27, p 658. Also, the Toleration Act 1689 (Quakers could make an affirmation in lieu of the oaths of supremacy and allegiance). See also Holdsworth, n 29, vol 8, pp 440-1. For the corporation oath of non-resistance contained in the Corporation Act 1661 (13 Cha 2 st 2 c 2 (rep)), see Plucknett, n 27, pp 423-5.

${ }^{124}$ This reflected the earlier view of Tyler (a cleric), n 9, pp 63-4 (in 1834) 'I shall take it for granted, that every one who professes to regard the Gospel [the Bible] as the rule of life, will feel, first, that all unnecessary oaths should be abolished, in whatever department of church or state they may be found; and, secondly, that whatever oaths... may still be deemed indispensible, they should always be administered with such marks of reverence and solemnity, as at once are due to the hallowed name of him who is invoked, and may be calculated to inspire a religious feeling of respect and a reverential awe, as well in the person sworn, as in all who witness the ceremony.' See also Ibid, p 86.

${ }^{125} 1867$ Report, $\mathrm{n}$ 122, $\mathrm{p}$ ix. The Report also recommended that all oaths which were retained have removed from them 'all promises which are no longer applicable to the present discharge of the duties of the office...Many, if not all, of these oaths, framed under a wholly different state of society contain engagements which now never are or could be fulfilled, and thus men are inevitably taught to trifle with the most sacred obligations.' For oaths relating to the City of London (a number of which were antiquated), see A Pulling, A Practical Treatise on the Laws, Customs and Regulations of the City and Port of London (1852), p 40 (oath of a common councilman), 61 (citizen), 75 (warden of the companies), 85 (liveryman), 116 (recorder), 134 (sheriffs), 143 (constables) and 421 (brokers).

${ }^{126} \mathrm{Ibid}, \mathrm{p} \mathrm{x}$, 'Oaths of general allegiance to the sovereign ought, we think, to be retained in case of admission to all great national offices of trust or importance; but we advise that in every such case the oath should be made as precise and exact as possible, and should bind him who takes it to allegiance to your Majesty and your successors, without entering into historical declarations as to the line of that succession.'

${ }^{127}$ Ibid, p xii.

${ }^{128}$ Ibid, pp xi-xii.

${ }^{129}$ Three members believed that oaths of fidelity should be retained in the case of the 'highest national offices'. Three members also opposed removing the declaration of conformity to the liturgy of the CoE required by the Act of Uniformity 1662, to be taken in the case of headships and fellowships of colleges. And, one member dissented from removing from oaths of allegiance all references to the Act of Settlement 1700. See pp xiii-xxiii.

${ }^{130} \mathrm{Ibid}, \mathrm{p}$ xiii.
} 
Oaths of allegiance have seldom, if ever, been found to be of any practical benefit to the persons or the institutions whose safety and stability it has been sought to maintain by imposing them. In peaceful and prosperous times they are not needed; in times of difficulty and danger they are not observed... These oaths are open to the further objection that they tend to spread an erroneous view of the relation which exists between the State and the citizen, and to suggest the notion that those who take them are bound to certain obligations from which their fellow-subjects who have not taken them are exempt. Framed for the purpose of ensuring the loyalty and obedience of one class of persons, the effect of these oaths on others may be to lead them to question the fact that these duties are incumbent upon all. ${ }^{131}$ (italics supplied)

In respect of oaths of fidelity, they noted:

Oaths of fidelity in the discharge of duties appear to us not defensible on the grounds of public necessity or advantage on which other oaths have been established and are maintained...An oath can no more furnish a public servant with a conscience than with intellectual capacity; yet the theory of its administration seems to imply that, sworn, he will probably do that which, unsworn, he would leave undone, and that the oath can create the sense of duty, to which, in fact, it only appeals...Promissory oaths are, in our opinion, not only useless, but hurtful to public morality. They are, or ought to be, administered with all the solemnity which attaches to oaths administered in courts of justice. Yet many are still administered which neither are, nor are intended to be, nor can be observed, and of which the words can hardly fail to raise a smile on the faces of those who impose and those who take them. Such oaths are an offensive mockery tending to discredit a solemn ceremony, which it is highly important should not be discredited.... We are... of opinion that promissory oaths should in all cases be abolished, and that in those few and special cases where it appears desirable that a promise should be made, it should be made in the form of a declaration... ${ }^{132}$ (italics supplied)

Thus, as can be seen, these dissentients believed that most promissory oaths should be abolished (they were not dealing with oaths given in legal proceedings which were affirmatory (declaratory)). And that those retained should be in the form of declarations.

\section{(c) Conclusion}

The opinion of the dissentients had much common sense and merit. After all, there was little point in going through the formality and administration of an oath, if there was no penalty for breach. Or, if the person did not believe in a deity appealed to. Or, if the person - while believing in a deity - did not believe that any moral punishment would flow from a breach of the oath. Or, if a solemn ceremony was treated with levity (or the oath with contempt). ${ }^{133}$ As it is, while not upholding the opinion of the dissentients, the 1867 Report made detailed recommendations as to:

(a) what oaths (and declarations) should be abolished;

(b) what oaths (and declarations) should be retained without alteration;

(c) what oaths should be altered;

(d) in which cases declarations should be substituted for oaths;

(e) those oaths (and declarations) for which shorter forms of declaration should be substituted.

In conclusion, the 1867 Report (especially, the opinion of certain dissentients) is an important starting point when considering the worth of retaining oaths today.

\footnotetext{
${ }^{131}$ Ibid, pp xv-xvi.

${ }^{132}$ Ibid, pp xvi-ii. The lack of solemnity and the number of oaths required had been adverted to by others such as the cleric RP Finch, Considerations upon the Use and Abuse of Oaths (1788), pp 19-20 who referred to the need to 'administer oaths with greater solemnity than is now usual; which is, indeed, shamefully neglected. Another, to appoint as few of them [oaths] as possible. Oaths given and taken frequently will be given and take irreverently, till at last many will regard them very little more than they do common swearing.'

${ }^{133}$ Ibid, p xix. 'Oaths taken on important occasions have been violated by persons of all ranks, ecclesiastics as well as laymen, sometimes with the connivance or even with the approval of the authorities whose duty it was to watch over their fulfilment. They have been taken under circumstances which could hardly fail to bring them into contempt, and in various ways have been treated as unmeaning forms by those to whose opinion or example the public have been disposed or accustomed to defer. Declarations, as might be expected, have been as nugatory as oaths. Few have continued for any length of time to act as a bar against wrong; some have even been turned into a screen for abuses which they were intended to prevent; and some, even with penal consequences attached to their falsification, seem to have been made falsely from their very enactment.'
} 


\section{PROMISSORY OATHS ACT 1868}

The 1868 Act was something of a compromise between the Commission on Oaths and its dissentient members. In summary:

- Oath of Allegiance. The Act (s 2) preserved this oath, but curtailed its form (viz. 'I [ ] do swear that I will be faithful and bear true allegiance to [HM], her heirs and successors, according to law. So help me God.'). The Act, also, limited the number of persons required to give it;

- Oath of Fidelity. The Act (s 3) preserved this oath (which it called the official oath), but curtailed its form (viz. 'I [ ] do swear that I will well and truly serve [HM] in the office of []. So help me God.' The Act, also, limited the number of persons required to give it;

- $\quad$ Judicial Oath. This had not been discussed in the 1867 Report in any detail (it was also treated as a form of oath of fidelity). The Act (s 4) provided a form of oath (viz. I [ ] do swear that I will well and truly serve [HM] in the office of [ ], and I will do right to all manner of people after the laws and usages of this realm, without fear or favour, affection or ill will. So help me God.)' The Act, also, limited the number of persons required to give it. And, it provided a variant for the Lord Chancellor to give.

The 1868 Act, s 11, permitted a person who was required to take any of the above oaths, to give an affirmation instead. ${ }^{134}$ It, also, dealt with a refusal to give any of the above oaths, s 7 (penalty on not taking required oath) stating:

If any officer specified in the schedule hereto declines or neglects, when any oath required to be taken by him under this Act is duly tendered, to take such oath, he shall, if he has already entered on his office, vacate the same, and if he has not entered on the same be disqualified from entering on the same; but no person shall be compelled, in respect of the same appointment to the same office, to take such oath or make such affirmation more times than one. ${ }^{135}$

The problem with the 1868 Act is that it left various matters unresolved. For example:

- Oath Retained. The Act - by still requiring an oath - failed to consider whether it would have not been (much) simpler to have replaced the above oaths, and all others, with a statutory declaration. This, to save the time and costs of administration as well as uncertainty and confusion, especially in the religious context;

- Penalty for Breach. The Act failed to indicate what would happen, legally (i.e. the punishment, sanction) if a person breached their oath (as opposed to refused to give it);

- Those Required to give an Oath. The list of those required in the 1868 Act to give oaths of allegiance and official oaths (i.e. oaths of fidelity, including judicial oaths), was quixotic - missing out persons who might be, otherwise, expected to be required to give the same;

- Form of the Oath. The form of the oaths set out in the 1868 Act was opaque, archaic and uncertain in law. For example, the words 'be faithful' and 'true' 136 in the oath of allegiance meant very little legally. Especially, when the system of Norman land tenure (based on homage and fealty) was obsolete in practice by 1868 . The words 'well and truly' in the oath of fidelity - and the words 'do right' and 'usages' etc in the judicial oath - also, meant little (probably the words 'do right' were the archaic version of 'do justice').

- What Oaths required at Common Law. The 1868 Act failed to indicate what oaths were still required at common law - leaving this uncertain.

In conclusion, the 1868 Act simplified the oath of allegiance, the official oath and the judicial oath. However, it failed to consider whether the latter two were of use. Further, it retained the oath - instead of replacing it wholly with a statutory declaration, which would have avoided religious considerations.

\footnotetext{
1341868 Act, s 11 'When an oath is required to be taken under this Act, every person for the time being by law permitted to make a solemn affirmation or declaration instead of taking an oath may, instead of taking such oath, make a solemn affirmation in the form of the oath hereby appointed, substituting the words 'solemnly, sincerely, and truly declare and affirm ' [for] 'So help me God.'

${ }^{135}$ For the consequences of refusing or neglecting to give an affirmation (declaration), see s 13 (it was of similar purport to s 11).

${ }^{136}$ This word would seem to refer to 'unconditional' allegiance, repeating the concept of 'liege' in 'allegiance', see Pollock \& Maitland, n 4, vol 1, p 298. However, this only referred to a person who owed allegiance both to the Crown (the king) and to a lord (mesne lord); thus, stressing that unconditional allegiance was owed to the former as opposed to the latter (especially, in the case of civil war). By 1868 , mesne lords were obsolete, in practice. So, too, in practice, paying homage and fealty.
} 


\section{LEGISLATIVE CHANGES TO OATHS 1888 - 1977}

\section{(a) Legislative Changes: 1888}

After the 1868 Act, various legislative attempts were made to further ameliorate the position (it being, retrospectively, realised that there was much merit in what the dissentients in the 1867 Report argued for). Thus, the Oaths Act $1888^{137}$ sought to cater for persons who had: (a) no religious belief; or (b) for whom the giving of an oath would be contrary to such. It provided for the giving of an affirmation as an alternative to an oath in all situations (including in legal proceedings), s 1 stating:

Every person upon objecting to be sworn, and stating, as the ground of such objection, either that he has no religious belief, or that the taking of an oath is contrary to his religious belief, shall be permitted to make his solemn affirmation instead of taking an oath in all places and for all purposes where an oath is or shall be required by law, which affirmation shall be of the same force and effect as if he had taken the oath... ${ }^{138}$ (italics supplied)

A further section (s 3), provided that:

Where an oath had been duly administered and taken, the fact that the person to whom the same was administered had, at the time of taking such oath, no religious belief, shall not for any purpose affect the validity of such oath. (italics supplied)

However, the effect of s 3 contradicted the very nature of an oath which - since time immemorial - comprised a religious affirmation (declaration) made in the fear of moral punishment by a deity. Thus, it would have been better if the Oaths Act 1888 had abolished all oaths and substituted a declaration (affirmation) instead.

\section{(b) Legislative Changes: 1888-1977}

Further piecemeal legislation in the period 1888-1961, followed, viz:

- Oaths Act 1909. It clarified the means of administering an oath; ${ }^{139}$

- Oaths Act 1961. It provided that a person might be required (as well as permitted) to affirm when it was not reasonably practicable (without inconvenience or delay) to administer an oath in the manner appropriate to his religious belief; ${ }^{140}$

- Administration of Justice Act 1977 (the 'AJA'), s 8. It widened the Oaths Act 1888, s 1, to state that: 'Any person who objects to being sworn shall be permitted to make his solemn affirmation instead of taking an oath in all places and for all purposes where an oath is or shall be required by law, which affirmation shall be of the same force and effect as if he had taken the oath.' (italics supplied)

In short, by 1977, more than 100 years after the 1868 Act, the law had become that a person could give an affirmation in lieu of an oath in all circumstances where an oath was legally required. And that - even if a person gave an oath - it did not matter if they had any religious belief or not. This latter position (Oaths Act 1888, s 3) should have led to oaths being replaced by declarations since it made the giving of an oath something of an absurdity (it would not seem appropriate for a person to make statements for legal purposes which they do not believe in).

In conclusion, none of Oaths Acts 1888-1977 considered the root issue of whether it was useful to retain an oath (being a religious affirmation) when it may have been better to turn the same into a declaration. Nor did

\footnotetext{
${ }^{137}$ This Act was the outcome of the atheist Charles Bradlaugh MP (1833-91) seeking to take his seat in Parliament. See also H Bradlaugh Bonner, Charles Bradlaugh, A Record of his Life (1898).

${ }^{138}$ Section 2 stated that such affirmation should be: 'I [X], do solemnly, sincerely, and truly declare and affirm' and then proceed with the words of the oath prescribed by law, omitting and words of imprecation or calling to witness.' Ibid. s 4 'Every affirmation in writing shall commence 'I [X] of [ ], do solemnly and sincerely affirm', and the form in lieu of the jurat shall be 'Affirmed at [ ], this [ ] day of [ ], 18[ ]. Before me.' The problem with this wording is that the words 'solemnly, sincerely, and truly [unconditionally] declare' add nothing to the word 'affirm' (itself, a synonym for 'declare'). Such wording originated from the 1868 Act, s 11 (rep), see n 134.

${ }^{139}$ Section 2(1) 'Any oath may be administered and taken in the form and manner following: The person taking the oath shall hold the New Testament, or in the case of a Jew, the Old Testament, in his uplifted hand, and shall say or repeat after the officer administering the oath the words 'I swear by Almighty God that...', followed by the words of the oath prescribed by law. (2) The officer shall (unless the person about to take the oath voluntarily objects thereto, or is physically incapable of so taking the oath) administer the oath in the form and manner aforesaid without question: provided that, in the case of a person who is neither a Christian nor a Jew, the oath shall be administered in any way which is now lawful.' The uplifted hand (in prayer) seem to derive from Babylonian and Assyrian practice, see n 19.

${ }^{140}$ Section 1(1)'The Oaths Act 1888 ... shall apply in relation to a person to whom it is not reasonably practicable to administer an oath in the manner appropriate to his religious belief as it applies in relation to a person objecting to being sworn on any such ground as is mentioned in [s 1] of that Act.'
} 
these Acts consider whether the oaths referred to in the 1868 Act (especially official and judicial oaths) were worth retaining. Not least, since there was no punishment for breach of any oaths (cf. refusal to give).

\section{OATHS ACT 1978}

In the period 1868-1977, the 'half-way house' laid down in the 1868 Act continued. However, this became problematic given an increasing decline in religiosity in England in post-Victorian times. Further, many oaths that were given (in some (or many) cases, regardless of any legal basis) in the case of guilds, schools, universities etc - such as were referred to in the 1867 Report - died out in the period 1868-1977, as a matter of practice. ${ }^{141}$ The Oaths Act 1978 was a good opportunity to wholly replace oaths with statutory declarations. Also, to further reduce the number of the same. However, the Act simply consolidated and repealed the Oaths Acts of 1838, 1888, 1909 and 1961 and s 8 of the AJA 1977, re-enacting the same in the following provisions:

- Manner of Administration of Oaths. S 1(1) "Any oath may be administered and taken in England, Wales or Northern Ireland in the following form and manner: The person taking the oath shall hold the New Testament, or, in the case of a Jew, the Old Testament, in his uplifted hand, and shall say or repeat after the officer administering the oath the words "I swear by Almighty God that . . . ..", followed by the words of the oath prescribed by law. (2) The officer shall (unless the person about to take the oath voluntarily objects thereto, or is physically incapable of so taking the oath) administer the oath in the form and manner aforesaid without question. (3) In the case of a person who is neither a Christian nor a Jew, the oath shall be administered in any lawful manner. (4) In this section "officer" means any person duly authorised to administer oaths.'

- Swearing with Uplifted Hand. S 3. 'If any person to whom an oath is administered desires to swear with uplifted hand, in the form and manner in which an oath is usually administered in Scotland, he shall be permitted so to do, and the oath shall be administered to him in such form and manner without further question.'

- Validity of Oaths. S 4(1) 'In any case in which an oath may lawfully be and has been administered to any person, if it has been administered in a form and manner other than that prescribed by law, he is bound by it if it has been administered in such form and with such ceremonies as he may have declared to be binding. (2) Where an oath has been duly administered and taken, the fact that the person to whom it was administered had, at the time of taking it, no religious belief, shall not for any purpose affect the validity of the oath.'

- Making of solemn Affirmations. S 5(1) 'Any person who objects to being sworn shall be permitted to make his solemn affirmation instead of taking an oath. (2) [ss] (1) above shall apply in relation to a person to whom it is not reasonably practicable without inconvenience or delay to administer an oath in the manner appropriate to his religious belief as it applies in relation to a person objecting to be sworn. (3) A person who may be permitted under [ss] (2) above to make his solemn affirmation may also be required to do so. (4) A solemn affirmation shall be of the same force and effect as an oath.'

- $\quad$ Form of Affirmation. S 6(1) 'Subject to [ss] (2) below, every affirmation shall be as follows: "I, do solemnly, sincerely and truly declare and affirm," and then proceed with the words of the oath prescribed by law, omitting any words of imprecation or calling to witness. (2) Every affirmation in writing shall commence: "I, of [ ], do solemnly and sincerely affirm," and the form in lieu of the jurat shall be "Affirmed at this day of 19 , Before me."

In conclusion, since the Oaths Act 1978 continued to provide that a person having no religious belief could give an oath - something of an absurdity ${ }^{142}$ - it would have been more appropriate to abolish all oaths and replace them with declarations. Also, to abolish all oaths at common law. And, to limit the number of statutory declarations required. Thus - rather like the 1868 Act, the Oaths Act 1978 left the law as clear as mud.

\section{OATHS TODAY}

(a) Modern Definition of an Oath

Walker, The Oxford Companion to Law, in 1980, defined an oath as:

\footnotetext{
${ }^{141}$ Cf. Tyler, n 9, p 70 (writing in 1834) 'I would... recommend the abolition of all oaths administered to members of our universities as such.' Oaths 'died out' (i.e. they were allow to lapse or they were formally dispensed with) since the institutions themselves no longer existed or - if they continued - they no longer sought to promote the giving of an oath (or an affirmation instead) prior to a person taking up an office with the institution.

${ }^{142}$ Stroud, n 3, vol 3, (oath) 'An oath is a religious affirmation, by which a person renounces the mercy and imprecates the vengeance of heaven if he do not speak the truth' quoting $R v$ White (1786), see 9(d).
} 
An assertion or promise made in the belief that supernatural retribution will fall on the taker if he violates what he swears to do...Many forms of oath are taken, among the most notable being the coronation oath, the oath of allegiance, the judicial oath, oaths taken by privy councillors, by peers on their creation, by MPs before sitting or voting, by archbishops and bishops, by aliens on naturalization, by jurors, and by witnesses before giving evidence... In many cases, persons who object to being sworn, having no religious belief, are entitled to make a solemn affirmation instead of taking an oath, with the same force and effect... As religious belief diminishes there is increasing doubt nowadays whether taking an oath has any effect on many witnesses, and whether the practice should be continued. ${ }^{143}$ (italics supplied)

That statement was made nearly 40 years ago. As it is, the position on oaths has not changed from the Oaths Act 1978. Oaths are still with us.

\section{(b) Administration of Oaths}

In respect of their administration, from a remote period, notaries exercised the right to administer oaths and take affidavits. ${ }^{144}$ Affidavits comprise written, sworn, statements of evidence used in judicial proceedings. They are used in cases where the general requirement for witnesses to give their evidence orally, and in open court, is waived (although, in proceedings in the senior courts of England and Wales, affidavits have been largely supplanted by witness statements). ${ }^{145}$ Today, only persons approved under the Courts and Legal Services Act 2007 (i.e. relevant authorised persons) can administer oaths. They include notaries. ${ }^{146}$ Brooke's Notary (2013) summarises the current manner of administering oaths:

The manner of administering oaths in England, Wales and Northern Ireland is regulated by the Oaths Act 1978 which... provides that any oath may be administered and taken in England, Wales and Northern Ireland in the following form and manner: that is to say, the person taking the oath shall hold the New Testament, or in the case of a Jew, the Old Testament, in his uplifted hand, and shall say, or repeat after the officer administering the oath, the words 'I swear by Almighty God that...' followed by the words of the oath prescribed by law. ${ }^{147}$

In the case of the administration of oaths out of England in connection with English proceedings, the text provides:

By s 3(1) of the Commissioners for Oaths Act 1889, any oath or affidavit required for the purpose of any court or matter in England, or for the purpose of the registration of any instrument in any part of the $[\mathrm{UK}]$, may be taken or made in any place out of England before any person having authority to administer an oath in that place. Persons who by English law have authority to administer oaths overseas include commissioners for oaths holding office in England and Wales and certain British diplomatic and consular officials. ${ }^{148}$

The modern law on oaths is laid down in Halsbury's Laws, albeit - as may be expected - there is no analysis as to whether oaths are worth retaining. ${ }^{149}$

\section{OATHS - WHAT SHOULD BE DONE ?}

As previously discussed, the law on oaths is unnecessarily complex and it has had a troubled history. It is asserted that all oaths, today, should be wholly abolished and replaced by declarations (which word is more easily understood, and used, than the word 'affirmation' today). The reasons for doing so are no different to

\footnotetext{
${ }^{143}$ DM Walker, The Oxford Companion to Law (1980)(oath). See also (affirmation) 'A solemn declaration that the defendant will tell the truth. By the Oaths Act 1888 [now, the Oaths Act 1978], any person objecting to taking an oath, on the ground of his religious belief or on the ground that he has no religious belief, may affirm to the same effect as if he had taken the oath. A person becoming a member of the House of Commons or of the House of Lords may affirm, instead of taking the oath of allegiance.'

${ }^{144}$ NP Ready, Brooke's Notary (14 ${ }^{\text {th }}$ ed, 2003), p 185 'English notaries have from a remote period exercised the right to administer oaths and take affidavits. These affidavits are for the most part intended for use overseas in countries where notarial acts are recognised. Notaries are also authorised to take statutory declarations in lieu of oaths.'

${ }^{145}$ Ibid, p 186. The formal requirements for affidavits are set out in the Civil Procedure Rules 1998, r 32. Ibid, pp 189-95.

${ }^{146}$ Ibid, pp 185-6.

${ }^{147}$ Ibid, p 187. The text then discusses the other situations arising under the Oaths Act 1978, including the use of an affirmation.

${ }^{148}$ Ibid, p 188. It continues 'Where the person taking the affidavit abroad does so by virtue of powers conferred on him by English law, judicial and official notice are taken of his seal and signature impressed or subscribed to or on any such oath or affidavit. Furthermore, the Civil Procedure Rules 1998 (r 32.17) enables affidavits for use in proceedings before the High Court to be made outside the jurisdiction in accordance with the law of the place where the affidavit is made. This may require proof of the applicable foreign law.'

${ }^{149}$ See n 16.
} 
those set out by the dissentients in the 1867 Report. However, they are even more compelling in modern times given the increasing decline in religiosity and the fact that we live in an electronic age. Thus:

- Oath is a Religious Declaration. The quintessence of an oath is that it comprises a religious declaration (affirmation). One in which a person tells the truth since they have a real fear of moral retribution by a deity, if they do not. Thus, it is inappropriate to utilise the same in the case of atheists and agnostics. Also, in the case of Christians (and those of other religions), if they have no fear of sacrilege as well as in the case of those who do not understand the true nature of an oath;

- Oaths - Religious Objections. An oath is, also, not appropriate for those with religious objections. Thus, Christ deprecated the use of oaths and many Christians believe that his words were intended to apply generally;

- Oaths - Not Enforceable. In the legal context, it is somewhat pointless to require an oath when there is no legal sanction for refusing to give the same. Or, where, there is no legal sanction for breach. Thus, there are no legal sanctions for the breach of the coronation oath or the breach of the oaths referred to in the 1868 Act - (i.e. an oath of allegiance, official oath or judicial oath; or the affirmations in lieu) since the same do not constitute perjury (or any other crime or civil offence) in the case of breach; ${ }^{150}$

- Oaths - Refusal/Neglect. The crime (penalty) of praemunire - which was, also, imposed for refusing to give certain statutory oaths - has been abolished. ${ }^{151}$ Thus, there is no penalty in refusing or neglecting to give any oath unless legislation so provides (as in the case of the $1868 \mathrm{Act}$ );

- Unlawful Oaths. As Coke pointed out (see 8), oaths are only lawful if sanctioned by the common law or legislation (otherwise, it is a 'high contempt' (i.e. a misdemeanour) to seek to administer one). However, many oaths still sought (likely) have no legal basis. Thus, strictly, they are unlawful;

- Form of Oath. The Oaths Act 1978 makes it clear that the form of the oath (or affirmation in lieu) need not be followed. Thus, there is little point in stipulating one. Further, the form of most oaths remains unclear, with little (or no) real legal significance. Therefore, if retained, their form should be further simplified;

- Oaths at Common Law. What oaths are still required at common law is uncertain. They all appear to be legislative now or they are obsolete (such as oaths of homage and fealty). ${ }^{152}$ Thus, any legal requirement for an oath at common law should be abolished;

- Time and Cost. Oaths (and affirmations) incur administrative time and cost. This is pointless if they are not required legally or - even if legally required - their retention is unnecessary.

In conclusion, this article argues that the dissentients in the 1867 Report got things right, in hindsight. As a result, all oaths should be abolished and replaced by statutory declarations. And, there should be very few of the latter. Such will help clarify the law as well as save time and administration. Further, there is no indication that any member of the public (or any lawyer) would object - save for those who make substantial sums from administering oaths. However, are there any persons making such a living today?

\section{WHAT OATHS SHOULD BE RETAINED ?}

What oaths should be retained in modern times? The position may be summarised as follows:

- Coronation Oath. This should become a declaration, shorn of religious content as it originally was. One in which the sovereign agrees to uphold the law (see 17);

- Oath of Allegiance. This should become a declaration (one which can be given orally or in writing). One only required to be given by: (a) those who enlist in the armed forces; and by (b) aliens (i.e. foreign citizens) on naturalisation. Any oath of allegiance given by an important person referred to in the 1868 Act should no longer be required. Nor by a CoE bishop (or archbishop), MP or regent. Finally, the form of this oath (qua declaration) should be further simplified (see $\mathbf{2 0} \& \mathbf{2 2}$ );

\footnotetext{
${ }^{150} \mathrm{Cf}$. Coke, text to $\mathrm{n} 99$. The position was the same in 1290, see Britton, $\mathrm{n} 62$.

${ }^{151}$ See n 101. See also Blackstone, n 101, vol 4, p 124 (crime of contempt of the king's title in failing to give various statutory oaths). See also Walker, n 143 (praemunire).

${ }^{152}$ Coke (in 1641), n 98, referred to statutory oaths given by privy counsellors, judges, sheriffs, attorneys, mayors and bailiffs. Oaths given by MP's were also statutory. The oath of a public notary is also statutory (see 26). Thus, today, there appear to be no oaths required at common law which are still extant, save for oaths of homage and fealty (which are obsolete save for ceremonial purposes in the case of the former) .
} 
- Official Oath/Judicial Oath. These should be abolished as unnecessary (see 20 \& 22), save for an official oath given in the case of a privy councillor (re secrecy, see 23) which should become a declaration;

- Oaths in Legal Proceedings. The oaths of a juror and a witness (as well as any other oaths required in legal proceedings) should become declarations. These should be further simplified (see 27);

- $\quad$ Legislation. All extant legislation relating to oaths should be repealed and matters should be set out in a modern Oaths and Declarations Act. This Act should, also, clarify who may administer any statutory declaration (formerly, an oath);

- $\quad$ Perjury. This crime should be abolished - to be replaced by one of making a false statutory declaration.

These matters are now considered, by analysing the following:

- Coronation Oath;

- Oath of a Regent;

- Oaths of Homage and Fealty;

- Official Oath;

- Judicial Oath;

- Oath of Allegiance;

- Privy Councillor's Oath;

- Parliamentary Oath;

- Church of England Oaths;

- Public Notary's Oath;

- Oaths in Legal Proceedings;

- Administration of Oaths;

- Perjury.

\section{OATHS TODAY - CORONATION OATH}

A prior article has analysed the nature, and history, of the coronation oath in detail. ${ }^{153}$

\section{(a) Form of the Coronation Oath}

When the coronation oath was first utilised in Anglo-Saxon England is unclear. However, the oath administered by the Archbishop of Canterbury, Dunstan (959-88 AD) at the coronation, in 973 AD, of king Edgar (959-75 AD) - which oath was threefold (tria precepta) - is recorded as being as follows (being translated from the Latin into English):

These three things I promise in Christ's name to the Christian people subject to me: ${ }^{154}$

First, that the church of God [i.e. the Catholic church] and the whole [i.e. all] Christian people shall have true peace at all time[s] by our judgment; ${ }^{155}$

Second, that I will forbid extortion and all kinds of wrong doing [i.e. crime] to all orders [i.e. classes] of men; ${ }^{156}$

Third, that I will enjoin equity and mercy in all [my] judgments, [so] that God, who is kind and merciful, may vouchsafe [i.e. extend] his mercy to me and to you. ${ }^{157}$

\footnotetext{
${ }^{153}$ GS McBain, The Religion of the Queen - Time for Change (2011) Queensland LR, pp 1- 48.

${ }^{154}$ Edgar was king of England. Further, the Christian references were likely imported by Dunstan, Archbishop of Canterbury (and his closest adviser). Thus, in effect the promise was: 'I promise...to the...people subject to me' (i.e. I promise my people).

${ }^{155}$ As for 'true peace' (vera pax), this concept tended to be closely allied to the concept of maintaining the law (especially, the criminal law). Thus, in effect, the promissory oath was (likely) that: 'I shall uphold (maintain) the law for the Catholic church and all my people.'

${ }^{156}$ The import was that the king would prevent crime, regardless of the status (class) of the people involved.

${ }^{157}$ McBain, n 153, p 40. Bracton, n 49, vol 2, p 304 (c. 1250) records the coronation oath in his time as follows: 'In the first place, that to the utmost of his power he will employ his might to secure and will enjoin that true peace shall be maintained for the church of God and all Christian people throughout his reign. Secondly, that he will forbid rapacity to his subjects of all degrees. Thirdly, that he will cause all judgments to be given with equity and mercy, so that he may himself be shown the mercy of a clement and merciful God, in order that by his justice all men may enjoy unbroken peace.' This wording may be compared with the oath of king Edgar in 973 AD (given more than 270 years before) since it (likely) sought to track the same.
} 
The development of a coronation oath appears to have arisen in the Visigothic kingdom in the 5-8 ${ }^{\text {th }}$ century and then spread. ${ }^{158}$ As Kern noted, the form of the oath varied and its essential purport was the duty of the sovereign to uphold (defend) the law in general. ${ }^{159}$ Thus, it was not intended to have an especially specific religious import and references to such were later 'add ons'. Because there was uncertainty as to the form of the oath by the time of the 'Glorious Revolution' (1688) ${ }^{160}$ - and probably because the Protestants wanted it in a more strident form the Coronation Oath Act 1688 laid down the form of the coronation oath. ${ }^{161}$

- $\quad$ Claim of Right 1689. The obligation to give the coronation oath was subsequently reflected in Scots legislation - the Claim of Right Act 1689 (still extant, it reflects the conditions on which the Crown of Scotland was offered to William and Mary who were at that time already king and queen of England). It declares: 'by the law of this kingdom [i.e. Scotland]...nor can any protestant successor exercise the regal power until he or she swear the coronation oath.'; ${ }^{162}$

- Act of Settlement 1700 . The obligation to give the coronation oath was also reflected in this Act of the English Parliament, s 2 providing 'every King and Queen of this Realm who shall come to and succeed in the imperial crown of this kingdom by virtue of this Act shall have the coronation oath administered to him her or them at their respective coronations according to the [Coronation Oath Act 1688] and shall make subscribe and repeat the declaration in the Act...in the manner and form thereby prescribed.' (wording modernised)

- Maintenance of the Church of England Act 1706. ${ }^{163}$ This Act required the sovereign to take an oath to maintain the settlement of the $\mathrm{CoE}$ and, that such a requirement should be inserted into the Act of Union between the kingdoms of Scotland and England. ${ }^{164}$ This occurred, the Union with Scotland Act 1706, art 25(3) stating: 'and be it further enacted by the authority aforesaid that after the demise of [HM] (whom God long preserve) the sovereign next succeeding to [HM] in the royal government of the kingdom of Great Britain and so for ever hereafter every king or queen succeeding and coming to the royal government of the kingdom of Great Britain at his or her coronation shall in the presence of all persons who shall be attending assisting or otherwise then and there present take and subscribe an oath to maintain and preserve inviolably the said settlement of the [CoE] and the doctrine worship discipline and government thereof as by law established within the kingdoms of England and Ireland the dominion of Wales and town of Berwick upon Tweed and the territories thereunto belonging.' This was inserted into the coronation oath, see below.

Although the Coronation Oath Act 1688 laid down the form of the coronation oath, extra-legislatively, this form has changed over time ${ }^{165}$ and that of Elizabeth II at the time of her coronation in 1953 was as follows:

[1] Will you solemnly promise and swear to govern the peoples of the [UK] of Great Britain and Northern Ireland, Canada, Australia, New Zealand, the Union of South Africa, Pakistan and Ceylon,

\footnotetext{
${ }^{158}$ F Kern, Kingship and Law in the Middle Ages (1968, trans SB Crimes), pp 75-6 'Solemn promises by a prince before he began to rule were here and there customary as early as the period of the folk- migrations, but apparently there were no durable rules with regard to such undertakings, until clerical influence gave rise to fixed traditions. This seems to have occurred first in the Visigothic kingdom. When, in the ninth century, the ceremonies for the inauguration came under ecclesiastical influence in the Frankish kingdom, the solemn undertakings subscribed by the monarch before his coronation assumed a form which, within certain modifications, set the standard for Western monarchy.'

${ }^{159}$ Ibid, p 77 'The coronation vows contained nothing to which the king was not otherwise bound. They simply re-affirmed the essential royal duty in which all the king's other duties were comprised: the duty to defend the law.'

${ }^{160} \mathrm{G}$ Crabb, A History of English Law (1829), p 558 'The old coronation oath, which was probably derived from the Saxons, and is referred to by ancient writers, was, as the statute [the Coronation Oath Act 1688] alleges, framed in doubtful terms with relation to ancient laws and constitutions.' The Coronation Oath Act 1688 states: 'Whereas by the law and ancient usage of this realm, the kings and queens thereof have taken a solemn oath upon the evangelists [i.e. the Bible] at their respective coronations, to maintain the statutes, laws, and customs of the said realm, and all the people and inhabitants thereof, in their spiritual rights and properties: but forasmuch as the oath itself on such occasion administered, hath heretofore been framed in doubtful words and expressions, with relation to ancient laws and constitutions at this time unknown...'

${ }^{161}$ McBain, n 153, p 9.

162 Ibid, p 21.

${ }^{163}$ This was also called an Act of 6 Anne $1706 \mathrm{c} 8$.

${ }^{164}$ Ibid, s 3 (this Act to be part of any Treaty of Union). 'And this Act and all and every the matters and things therein contained be and shall for ever be holden and adjudged to be a fundamental and essential part of any Treaty of Union to be concluded between the said two kingdoms and also that this Act shall be inserted in express terms in any Act of Parliament which shall be made for settling and ratifying any such Treaty of Union and shall be therein declared to be an essential and fundamental part thereof.'

${ }^{165}$ The historical alterations are discussed in detail in McBain, n 153.
} 
and of your possessions and the other territories to any of them belonging or pertaining, according to their respective laws and customs?

[2] Will you to your power ${ }^{166}$ cause law and justice in mercy to be executed in all your judgements?

$[3]$

- Will you to the utmost of your power maintain the laws of God and the true profession of the gospel?

- Will you to the utmost of your power maintain in the [UK] the protestant reformed religion established by law? [inserted by the Coronation Oath Act 1688]

- And will you maintain and preserve inviolably the settlement of the [CoE], and the doctrine, worship, discipline, and government thereof, as by law established in England? [inserted in 1706, see above]

- And will you preserve unto the bishops and clergy of England and to the churches there committed to their charge, [i.e. to the clergy of the $\mathrm{CoE}$ and their churches] all such rights and privileges, as by law do, or shall appertain to them, or any of them $?^{167}$ (italics supplied)

As with the oath of King Edgar, that of Elizabeth II was tri-partite. However, her third oath mainly stems from 1688 and later, with only her first two oaths echoing back to the coronation oath of king Edgar in 973 AD. ${ }^{168}$

\section{(b) Need to Change the Form of the Coronation Oath}

The form of the first oath will need to be changed in the case of any successor to the present sovereign. ${ }^{169}$ However, there are general problems with the coronation oath in any case, today:

- The first is that it is not legally binding (enforceable) and never was;

- The second is that the sovereign - with regard to the first oath - does not really 'govern' as she did in times past, especially in the case of non-UK countries. Her power, today, is ceremonial (formal) rather than executive; ${ }^{170}$

- The third, is that - with regard to the second oath - (the sovereign promising to cause her 'judgements' (presumably, this refers to her decisions as sovereign) to be executed according to 'law and justice' this means little today since the sovereign no longer has any judicial power ${ }^{171}$ and she only takes decisions under advice;

- The fourth is that, as regards the third oath - which is wholly religious - such was predicated on the sovereign having the legal power to prevent (that is, to 'maintain' or 'preserve'), change or dispense with legislation relating to the CoE. However, the sovereign no longer has such power. Indeed, since 1688, Parliament has been supreme and it may make, and repeal, legislation as it will without regard to the opinion of the sovereign (her role being formal now). Therefore, this oath is much of a brutum fulmen;

- The fifth is that, as regards the third oath - such is predicated on the sovereign being a Protestant and, more especially, a member of the CoE (or, possibly, only adhering to its doctrine). However, today, the sovereign may not, privately, be - or wish to be - of any religion or of the Protestant religion (including

\footnotetext{
${ }^{166}$ The word 'power', probably, was a synonym for 'ability'. Cf. OED, n 2, (power) '2. Ability to act or affect something strongly; physical or mental strength; might; vigour; energy; force of character; telling force, effect.'

${ }^{167}$ The words 'true profession' of the gospel refer to the Bible as interpreted by the CoE.

${ }^{168}$ The second oath of Elizabeth II reflects most clearly the third oath of Edgar, see n 157.

${ }^{169}$ Probably, to something like: 'Do you promise to govern the peoples of the [UK] of Great Britain and Northern Ireland, Canada, Australia, New Zealand and your other territories, according to their respective laws and customs? The references South Africa, Pakistan and Ceylon (Sri Lanka) need to be dispensed with since they are now independent countries. Further, 'possessions' no longer exist, legally, as such. They have become British Overseas Territories. Thus, a simple reference to 'territories' would seem advisable for the future. Further, the words 'solemnly promise' add nothing to the word 'swear'. Reference to 'promise' alone, however, reflects the wording in the coronation oath of king Edgar, see n 157.

${ }^{170}$ As Halsbury, n 16, vol 20, para 16, notes 'in accordance with the conventions or principle of constitutional monarchy, the monarch's public legal acts and duties are exercised in accordance with ministerial advice.'

${ }^{171}$ Ibid, para 16: 'The power of doing justice in the courts has been irrevocably delegated to the judges and magistrates, so that the monarch may take no part in the proceedings in the court of justice. Since, in addition, the monarch can no longer without the consent of both Houses of Parliament remove any of the judges of the senior courts, and all decisions of inferior courts are subject to review by the senior courts, the monarch has lost all power of influencing judicial decisions.'
} 
that of the $\mathrm{CoE}$ ). Further, there would seem no good reason for the human right as respects religion ${ }^{172}$ to not also apply to the sovereign. Thus, a requirement to give the third oath may not be appropriate;

- The sixth is that, as regards the third oath, it is not old. It was not in the oath given by king Edgar in Anglo-Saxon times (see above). Further, the wording as to the "protestant reformed religion established by law' was only added by the Coronation Oath Act $1688 .{ }^{173}$ Similarly, the wording 'And will you maintain and preserve inviolably the settlement of the [CoE], and the doctrine, worship, discipline, and government thereof, as by law established in England?' was only inserted by virtue of the Maintenance of the Church of England Act 1706 (and repeated in the Union with Scotland Act 1706) in a more extended version - which version was, subsequently, reduced in scope to reflect the dis-establishment of the Church of Ireland in 1871 and the Church in Wales in 1920;

- The seventh is that the CoE (and any other Protestant denomination) is Christian and Christ (it appears) deprecated the giving of oaths (it seems, on the basis, that it was an invitation to people to, then, seek to avoid them). Thus, a coronation oath may not be appropriate and a declaration (instead of an oath) less problematic, today.

For the above reasons, it is asserted that consideration should be given to changing the coronation oath into a declaration and making it more in accord with the original oath of king Edgar in 973 AD. In particular, that the third oath - which means that the sovereign promises to uphold the 'established' (a reference to the legal) status of the $\mathrm{CoE}$ as a State church - be excised. This, on the grounds indicated above. Particularly, on the basis that such an oath is not legally binding (that is, there is no legal sanction for breach) and that the sovereign has no longer any power (legal, judicial or executive) over such matters. Also, that it is not especially appropriate in modern times when the sovereign should be entitled to be of such religion as he (or she) wishes (or of no religion at all) - just like everyone else.

\section{In conclusion, it is asserted that the coronation oath should be changed into a declaration. Further, the third} oath (upholding the legal status of the CoE) should be dispensed with.

\section{(c) Declaration (Affirmation) on Accession}

Besides a coronation oath (and regardless of whether the sovereign has a coronation or not), a new sovereign gives a declaration (affirmation) on accession. The declaration is a religious one, the form being, as Halsbury notes:

I [monarch's name] do solemnly and sincerely in the presence of God profess, testify and declare that I am a faithful Protestant, and that I will, according to the true intent of the enactments which secure the Protestant succession to the throne of my realm, uphold and maintain the said enactments to the best of my powers according to law. ${ }^{174}$

The meaning of the words 'faithful protestant' is unclear. So too, whether the sovereign has to 'do' anything about it being such (i.e. to attend church etc). Further, unlike the coronation oath, this declaration is not old. It derives from the religious disturbances in the reign of Charles II (1660-85) who was, nominally, a Protestant but (probably) a secret Catholic. The legal requirement to give such a declaration is contained in the Bill of Rights 1688 (still extant) which provides that:

every king and queen of this realm who at any time hereafter shall come to and succeed in the imperial crown of this kingdom shall on the first day of the meeting of the first Parliament next after his or her coming to the Crown sitting in his or her throne in the House of Peers in the presence of the lords and commons therein assembled or at his or her coronation before such person or persons who shall administer the coronation oath to him or her at the time of his or her taking the said oath (whichever shall first happen) make subscribe and audibly repeat the declaration mentioned in the [Second Test Act 1678$].{ }^{175}$ (spelling modernised)

\footnotetext{
${ }^{172}$ Human Rights Act 1998, s 13 and Sch 1 (containing the Human Rights Convention, art 9 of which provides that: '1. Everyone has the right to freedom of thought, conscience and religion; this right includes freedom to change his religion or belief and freedom, either alone or in community with others and in public or private, to manifest his religion or belief, in worship, teaching, practice and observance. 2. Freedom to manifest one's religion or beliefs shall be subject only to such limitations as are prescribed by law and are necessary in a democratic society in the interests of public safety, for the protection of public order, health or morals, or for the protection of the rights and freedoms of others). See also McBain, n 153, p 33.

${ }^{173}$ McBain, n 153, p 9.

${ }^{174}$ Halsbury, n 16, vol 29, para 15 'This declaration was made by Elizabeth II from the throne in the House of Lords on 4 November 1952.' It may be noted that this declaration can be reserved for the coronation (which would seem better). Thus, George VI (1936-52) made his declaration at his coronation. See McBain, n 153, pp 4-8.

${ }^{175}$ For the Second Test Act 1678, see n 110.
} 
The need for a declaration arose from the religious hysteria emanating from the Popish Plot of 1678. The declaration required by the Second Test Act 1678 was avowedly anti-Catholic and did not refer to any other religion or Protestant sect. ${ }^{176}$ By the $20^{\text {th }}$ century the language of this declaration (affirmation) was regarded as too offensive and the form presently used (see above) was substituted by the Accession Declaration Act 1910 which (it seems clear) left the wording opaque so as to satisfy some protestant non-conformists. However, there are problems with the current form of the oath, if retained, viz.

- 'Protestant'. On a narrow construction of this word, it means that the sovereign is affirming that he (or she) is a member of the CoE. This would also be a likely modern interpretation - given that the coronation oath of Elizabeth II is now (much) more directed to the CoE than hitherto (see the coronation oath wording above in (a) above) $;^{177}$

- 'Faithful Protestant'. As for the word 'faithful', there are various possible meanings. For example, that the sovereign: (a) simply believes in the form of religion (doctrine) expounded by Protestants (or the $\mathrm{CoE}$ ), but no more; or (b) is, also, a practising member (i.e. attends church, takes communion etc) at a Protestant (CoE) church; or (c) is, also, morally (religiously) upright. However, if one considers the personalities of the sovereigns who have given this declaration in the past, few can be said to have been much interested in (a) or (b) and a number did not meet (c); ${ }^{178}$

- 'Uphold and Maintain'. The sovereign declares that he/she will 'uphold and maintain the said enactments to best of my powers according to law.' The reference to the 'enactments' seems clear enough. They refer to the Bill of Rights 1688 and the Act of Settlement 1700. However, the remaining wording means little since the sovereign, today, has no influence over legislation whether at an executive or a judicial level. Thus, the sovereign cannot prevent, change or dispense with legislation passed by Parliament which can repeal these Acts if so minded. The words 'uphold' and 'maintain' which are synonyms and (probably) mean the same as the word 'defend' - are someone vacuous and were (likely) so intended. ${ }^{179}$ They also (probably) mean no more than similar wording in the coronation oath: 'Will you to the utmost of your power maintain in the [UK] the protestant reformed religion established by law?'

In conclusion, this declaration - one which did not exist prior to 1678 and whose present wording stems from 1910 - should be dispensed with. It, effectively, declares that the sovereign is a member of the CoE (see also (d) below). It is not legally binding, it is opaque in nature and the latter part of the declaration is also covered by the coronation oath. It may be noted that this declaration was sought to be dispensed with in $1910 .{ }^{180}$

\section{(d) Communion with the $\mathrm{CoE}$}

As well as the coronation oath (see (a) above) and the declaration required of a new sovereign (see (c) above), the Act of Settlement 1700, s 3, provides that:

whosoever shall hereafter come to the possession of this Crown shall join in communion with the

[CoE] as by law established (italics supplied).

As to the meaning of the words 'in communion with' the CoE, this (likely) means membership of the same - a not unexpected requirement since the sovereign is the supreme governor of the CoE. ${ }^{181}$ As a result, the coronation oath and the declaration required of a new sovereign (likely) should, also, be construed as only referring to the CoE (this, post-1706).

\footnotetext{
176 Thus, the Bill of Rights 1688 provided the following declaration: 'I [the sovereign], do solemnly and sincerely, in the presence of God, profess, testify, and declare that I do believe that in the sacrament of the Lord's Supper there is not any transubstantiation of the elements of bread and wine into the body and blood of Christ, at or after the consecration thereof by any person whatsoever; and that the invocation or adoration of the Virgin Mary or any other saint, and the sacrifice of the mass, as they are now used in the Church of Rome, are superstitious and idolatrous. And I do solemnly, in the presence of God, profess, testify, and declare, that I do make this declaration and every part thereof in the plain and ordinary sense of the words read unto me, as they are commonly understood by English protestants, without any evasion, equivocation, or mental reservation whatsoever, and without any dispensation already granted me for the purpose by the pope, or any other authority or person whatsoever, or without any hope of any such dispensation from any person or authority whatsoever, or without thinking that I am or can be acquitted before God or man, or absolved of this declaration or any part thereof, although the pope or any other person or persons or power whatsoever should dispense with or annul the same or declare that it was null and void from the beginning.'

${ }^{177}$ See McBain, n 153, p 7.

${ }^{178}$ Ibid.

${ }^{179}$ McBain, n 153, p 8.

${ }^{180}$ Ibid, p 6, n 26 and p 36, n 176.

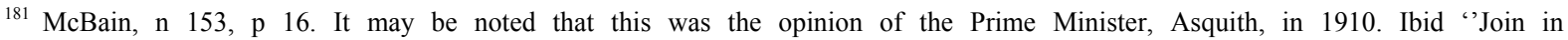
communion'...means have fellowship or membership with the particular religious body to which reference is made.'
} 


\section{(e) Oath to Church of Scotland}

As well as giving an oath to maintain the $\mathrm{CoE}$, the sovereign is required to give an oath to maintain the Church of Scotland ('CoS'). Thus, the Union with England Act 1707, art 25(2) re-states the words of the Protestant Religion and Presbyterian Church Act 1707 (also called, the 'Church of Scotland Act 1707'). ${ }^{182}$ It provides that, after the death of Queen Anne (1702-14), the next sovereign:

shall in all time coming at his or her accession to the Crown swear and subscribe that they shall inviolably maintain and preserve the aforesaid settlement of the true protestant religion with the government worship discipline right and privileges of this church [i.e. the CoS] as above established by the laws of this kingdom [i.e. Scots law] in prosecution [i.e. furtherance] of the Claim of Right [1689]. ${ }^{183}$

However, unlike in England - where the coronation oath set out in the Coronation Oath Act 1688 refers to the maintenance of the CoE (see (a), the third oath, point 3) - the oath vis-a-vis the CoS was not inserted into the coronation oath. Instead, the oath, vis-a-vis the $\mathrm{CoS}$, is given by the sovereign at the first meeting of the Privy Council following his (or her) accession to the throne. ${ }^{184}$ Finally, mention may be made of old pre-Union (i.e. pre-1707) Scots legislation - the Coronation Oath Act 1567 which (as anglicised) states:

Item: because that the increase of virtue and suppressing of idolatry craves that the Prince and the people be of one perfect religion which of God's mercy is professed within this realm. Therefore it is stated and ordained by our sovereign lord my lord regent and the estates of this present Parliament that all kings and princes or magistrates whatsoever holding their place which hereafter at any time shall happen to reign and bear rule over this realm at the time of their coronation and receipt of their princely authority make their faithful promise by oath in [the] presence of the eternal God that during the whole course of their life they shall serve the same eternal God to the uttermost of their power according as he has required in his most holy word revealed and contained in the New and Old Testaments.

And according to the same word [they] shall maintain the true religion of Jesus Christ the preaching of his holy word and due and right administration of the sacraments now received and preached within this realm. [i.e. the CoS].

And [they] shall abolish and gainstand [gainsay] all false religion contrary to the same.

And [they shall rule the people committed to their charge according to the will and command of God revealed in his aforesaid word and according to the lawful laws and constitutions received in this realm [which are] nowise repugnant to the said word of the eternal God.

And [they] shall procure to the uttermost of their power to the church of God and all Christian people true and perfect peace in all time coming [also] the rights and rents with all just privileges of the Crown of Scotland to preserve and keep inviolate neither shall they transfer nor alienate the same.

[And] They shall forbid and repress in all estates and degrees robbery [reif] oppression and all kind of wrong.

In all judgments they shall command [and] procure that justice and equity be kept to all creatures without exception as the Lord and Father of all mercies be merciful to them.

And out of their lands and empire they shall be careful to root out all heretics and enemies to the true worship of God that shall be convicted by the true church of God [i.e. the CoS] of the aforesaid crime.

\footnotetext{
${ }^{182}$ Ibid, p 19. This Act (1707 c 6) is also called the Act for the Security of the Church of Scotland and it was passed on 12 November 1706. See also F Lyall, Of Presbyters and Kings (1980), p 21. The Union between England and Scotland took effect on 1 May 1707.

${ }^{183}$ As with the Act for the Maintenance of the Church of England 1706 which became part of the (English) Union with Scotland Act 1706 (see n 164), the wording in the Protestant Religion and Presbyterian Church Act 1706, s 3 stated 'And it is hereby statute and ordained that this Act of Parliament with the establishment therein contained shall be held and observed in all time comeing as a fundamental and essential condition of any Treaty or Union to be concluded betwixt the two kingdoms without any alteration thereof or derogation thereto in any sort for ever. As also that this Act of Parliament and settlement therein contained shall be inserted and repeated in any Act of Parliament that shall pass for agreeing and concluding the foresaid Treaty or Union betwixt the two kingdoms and that the same shall be therein expressly declared to be a fundamental and essential condition of the said treaty or union in all time coming.' This happened with the wording of the Presbyterian Religion and Protestant Church Act 1707 becoming art 25 of the Union with England Act 1707. It was also inserted into the Union with Scotland Act 1706, art 2.

${ }^{184}$ Ibid, p 19. See London Gazette, 12 Feb 1952, 861 (now online, see www.london-gazette.co.uk) recording the signing of the oath by Elizabeth II at Whitehall on 7 Feb 1952.
} 
And that they shall faithfully affirm the things above written by their solemn [coronation] oath. ${ }^{185}$ Given that this oath (which would only be given at a Scots coronation) endorses the CoS, and that it is prior to the Acts of 1707 above referred to, it may be appropriate for it now to be dispensed with, as obsolete.

It is asserted, for the same reasons in respect of the oath given by the sovereign to the CoE - in particular, on the basis that the oath is not legally binding and that the sovereign now has no power in respect of legislation (whether English or Scots) - that this oath to the CoS also be dispensed with.

\section{(f) Title of 'Defender of the Faith'}

The sovereign bears the title 'Defender of the Faith', a title originally given to Henry VIII (1509-47) by a Catholic pope. ${ }^{186}$ It was confirmed by an Act of 1543-4 (now repealed). ${ }^{187}$ Today, the reference to the 'faith' being defended is that of the $\mathrm{CoE}$ and - as to its being 'defended' - this reflects the coronation oath and the declaration in (c) above. Obviously, if they go, so should this title (it can be dispensed with by means of a Proclamation pursuant to the Royal Titles Act 1953). ${ }^{188}$

\section{(g) Conclusion}

The coronation oath should become a declaration and be shorn of its religious content. Further, the:

- declaration given to the $\mathrm{CoE}$;

- requirement that the sovereign be 'in communion with' the CoE;

- $\quad$ title 'Defender of the Faith';

- $\quad$ oath given to the $\mathrm{CoS}$;

- Scots Coronation Oath Act 1567,

should, also, be dispensed with. Such would clear out much antiquated and opaque legislation.

\section{OATH OF A REGENT}

The Regency Act 1937 provides for a regency: (a) if the sovereign is under the age of 18 on his (her) accession; or (b) in the event of the total incapacity of the sovereign. ${ }^{189}$ The Act also makes provision for the delegation of royal functions to a regent, with s 4 (oaths to be taken by, and limitations of power of, regent)(1) providing that:

The regent shall, before he acts in or enters upon his office, take and subscribe before the Privy Council the oaths set out in the Schedule to this Act, and the Privy Council are empowered and required to administer those oaths and to enter them in the [Privy] Council books. ${ }^{190}$

The oaths in the Schedule to the Act comprise the following:

- I swear that I will be faithful and bear true allegiance to [here insert the name of the sovereign] his heirs and successors according to law. So help me God. [i.e. an oath of allegiance]

\footnotetext{
${ }^{185}$ The original Scots version is: 'Item Because that the incres of vertew and suppressing of Idolatrie crauis that the Prince and the peple be of ane perfyte Religioun quhilk of Goddis mercie is now presentlie professit within this Realme Thairfoir it is statute and ordanit be our Souerane Lord my Lord Regent and thre Estatis of this present Parliament that all Kingis and Princes or magistratis quhatsumeuer halding thair place quhilkis heirefter in ony tyme sall happin to Regne and beir reule ouer this Realme at the tyme of thair coronatioun and ressait of thair princely authoritie mak thair faithfull promise be aith in presence of the eternall God that induring the haill cours of their lyfe thay sall serue the samin eternall God to the vttermaist of thair power according as he hes requyrit in his maist haly word reuelit and contenit in the new and auld Testamentis And according to the samin word sall mantene the trew Religioun of Jesus Christ the preicheing of his haly word and dew and rycht ministratioun of the Sacramentis now ressaifit and preichit within this Realme And sall abolische and gainstand all fals Religioun contrare to the samin And sall reule the pepill committit to thair charge according to the will and command of God reuelit in his foirsaid word and according to the louabill Lawis and constitutiounis ressaifit in this Realme nawyse repugnant to the said word of the eternall God And sall procure to the vttermaist of thair power to the Kirk of God and haill cristiane pepil trew and perfyte peice in all tyme cuming The rychtis and rentis with all iust priuilegeis of the Crowne of Scotland to preserue and keip inuiolatit nouther sal thay transfer nor alienat the samin Thay sal forbid and repres in all Estatis and degreis reif oppressioun and all kynde of wrang In all Jugementis thay sall command and procure that Justice and equitie be keipit to all creaturis without exceptioun as the Lord and father of all mercyis be mercifull to thame And out of thair landis and Empyre thay salbe cairfull to ruite out all Heretykis and enemeis to the trew worschip of God that salbe conuict be the trew Kirk of God of the foirsaidis crymis And that thay sall faithfullie affirme the thingis abone writtin be thair solempnit aith.' Lyall, n 182, p 16 the 1567 Act required 'all future monarchs to swear to protect the true church as established, and to root out all those opposed to its teaching. This was of more political than legal interest...' See also Ibid, p 19 referring to the Claim of Right Act 1689, s 1 (James VII held to have forfeited the throne of Scotland, inter alia, because he had failed to give the 1567 oath on accession).

${ }^{186}$ McBain, n 153, p 27.

${ }^{187}$ See the Act for the Ratification of the King's Majesty's Stile (1543-4, 35 Hen 8 c 3, rep).

${ }^{188}$ McBain, $\mathrm{n} 153$, p 27. It appears that Canada and New Zealand still retain this title of the Commonwealth countries.

${ }^{189}$ Ibid, pp 28-31.

${ }^{190}$ See also Halsbury, n 16, vol 29, para 17 'The regent must swear certain oaths before he or she acts in or enters upon his or her office.'
} 
- I swear that I will truly and faithfully execute the office of regent, and that I will govern according to law, and will, in all things, to the utmost of my power and ability, consult and maintain, the safety, honour and dignity of [here insert the name of the sovereign] and the welfare of the people. So help me God. [i.e. an official oath]

- I swear that I will inviolably maintain and preserve in England and in Scotland the settlement of the true protestant religion as established by law in England and as established in Scotland by the laws made in Scotland in prosecution [i.e. in furtherance] of the Claim of Right [1689], and particularly by an Act intitled 'An Act for Securing the Protestant Religion and Presbyterian Church Government' [i.e. the Act for the Security of the Church of Scotland 1707] and by Acts passed in the Parliament of both kingdoms for [the] Union of the two kingdoms, together with the government, worship, discipline, rights and privileges of the Church of Scotland. So help me God. ${ }^{191}$ [i.e. an oath to maintain the $\mathrm{CoE}$ and the CoS]

Oaths, being religious, the reference to 'So help me God' is apposite. It is asserted that - as with the oath of allegiance and the oath of fidelity (official oath) in the 1868 Act - these oaths should no longer be required in the case of a regent. Not least, since they are not legally enforceable. Further, that the third oath - to maintain the $\mathrm{CoE}$ and the $\mathrm{CoS}$ - should also be dispensed with. Not least, in that a regent has no power over these matters.

\section{In conclusion, any oath required of a regent should be abolished.}

\section{OATHS OF HOMAGE \& FEALTY}

\section{(a) Concepts of Homage \& Fealty}

It is trite law that - as from the Norman Conquest (1066) - all land was owned by the Crown since William I (1066-87) asserted title to all England. William I, then, granted away land to his followers and others in return for services. ${ }^{192}$ These Norman forms of land holding (called tenure, from the latin tenere, to hold) - which were predicated on the basis of land being held in return for the tenant providing a service ${ }^{193}$ - were as follows:

- $\quad$ knight service, ${ }^{194}$

- $\quad$ sarjeanty service (grand and petit); ${ }^{195}$

- frankalmoign and divine service, ${ }^{196}$

- common socage service, ${ }^{197}$ this, also, being the residual service tenure.

Thus, such tenants (about 1500 or so of them in 1086) - being in capite (i.e. holding directly of the Crown as tenants in chief) - were bound to the Crown for their land. These tenants in capite then, usually, sub-divided their land, giving it to free men (free tenants) who held it of them in return for services. All land tenure by way

\footnotetext{
${ }^{191}$ McBain, n 153, p 30.

${ }^{192}$ See also: (a) C Harpum et al (eds), Megarry and Wade, The Law of Real Property (8 ${ }^{\text {th }}$ ed, 2012), ch 2; (b) SFC Milsom, Historical Foundations of the Common Law (2 $2^{\text {nd }}$ ed 1981); (c) AWB Simpson, An Introduction to the History of the Land Law (2 ${ }^{\text {nd }}$ ed, 1986); (d) EH Burn \& J Cartwright, Cheshire \& Burn's Modern Law of Real Property (18 $\left.8^{\text {th }} \mathrm{ed}, 2011\right)$ ('Cheshire').

${ }^{193}$ Harpum, n 192, p 23 'Each of these sets of [feudal] services [e.g. knight service etc] was known as a tenure, because it showed upon what terms the land was held (tenere, to hold)'. See also Coke, n 76, vol 1, s 1 (Co Litt 1a).

${ }^{194}$ JG Riddall, Land Law (2003), p 13 'A tenant who held by the tenure of knight service was originally obliged to provide his lord with a specified number of fully armed horsemen. By the middle of the twelfth century the obligation to provide men had largely been commuted for a fixed money payment, termed 'scutage'. By the end of the Middle Ages, with the decline in the value of money, scutage had largely ceased to be collected.' See also Simpson, n 192, pp 3, 7-8.

${ }^{195}$ Ibid, p 13 (grand sarjeanty) 'A tenant who held by the tenure of grand sarjeanty did so in return for performing some service of an honourable character, e.g. holding an office of state, such as that of chamberlain, or performing a particular service, as at the king's coronation.' Ibid, p 14 (petty serjeanty) 'When the king granted land to a tenant in return for services of a non-personal nature, such as carrying his letters, or feeding his hounds or hawks, or providing him with arrows, or straw for his bed, then the tenant held by the tenure of petty sarjeanty.' Grand sarjeanty was a military tenure. See also Harpum, n 192, p 24; Cheshire, n 192, p 40 and Simpson, n 192, pp 9-10, $13-4$.

${ }^{196}$ See Harpum, n 192, p 24; Riddall, n 194, p 13 and Simpson, n 192, p 10.

${ }^{197}$ Riddall, n 194, p 14 (commons socage) 'The service most commonly rendered under this form of tenure was of an agricultural character, both the nature (e.g. ploughing) and the amount (e.g. 20 days a year) being fixed. But the services were not necessarily of an agricultural nature, and many other kinds are recorded. In towns a form of common socage existed under which money rents were rendered instead of services. This form of common socage is termed 'burgage tenure'. Common socage was a residuary class of free tenure: if the free tenure was not provided to be of the others, then it was held to be in common socage. By the end of the fifteenth century the services rendered in payment in connection with common socage had largely been commuted into money payments, sometimes called 'quit rents' (by which the tenant became quit of his services). Like scutage, by the end of the Middle Ages quit rents had largely ceased to be collected.'
} 
of service (invariably) included the giving of oaths of homage and of fealty in exchange for the same. As to the distinction between these (homage including fealty but fealty not, necessarily, including homage): ${ }^{198}$

- Homage. Homage created an obligation by the tenant to his lord to render assistance to the latter in return for protection. ${ }^{199}$ Thus, a bond (also, called a ligament or tie) was formed between them. The oath of homage ${ }^{200}$ - a military oath - tended to be only given if the tenure was that of knight service. However, it could also be given (more rarely) in the case of common socage. Homage (save in a ceremonial capacity at the coronation) was abolished by the Tenures Abolition Act 1660 (there is a statutory exception, see below).The legal writer, Littleton, in his Tenures (c. 1481), stated:

Homage is the most honourable service, and most humble service of reverence, that a franktenant [free tenant] may do to his lord. For when the tenant shall make homage to his lord, he shall be ungirt, and his head uncovered, and his lord shall sit, and the tenant shall kneel before him on both his knees, and hold his hands jointly together between the hands of his lord, and shall say thus: 'I become your man (jeo deveigne vostre home) from this day forward of life and limb, and of earthly worship, and unto you [I] shall be true and faithful, and bear to you faith [i.e. faithful service] for the tenements [land] that I claim to hold of you, saving the faith that I owe unto our sovereign lord the king; and then the lord so sitting shall kiss him. ${ }^{201}$ (spelling modernised)

On the coronation of Elizabeth II in 1953, 'homage' was (ceremonially) paid by peers. ${ }^{202}$

- $\quad$ Fealty. This created an obligation on the part of the tenant to his lord to faithfully perform the service he was obliged to perform. ${ }^{203}$ Fealty did not apply in the case of frankalmoign, ${ }^{204}$ but it could apply in the case of divine service. The legal writer, Littleton, stated as to fealty:

Fealty is the same that fidelitas is in latin. And when a freeholder does fealty to his lord, he shall hold his right hand upon a book, and shall say thus: know you this, my lord, that I shall be faithful and true [loyal] unto you, and [in] faith to you shall bear [service] for the lands which I claim to hold of you, and that I shall lawfully do to you the customs and services which I ought to do, at the terms assigned, so help me God and his saints; and he shall kiss the book [the Bible]. But he shall not kneel when he makes his fealty, nor shall [he] make such humble reverence as is aforesaid in homage. ${ }^{205}$ (spelling modernised)

Although homage was, generally, abolished in 1660, there is a statutory exception as Cripps noted, in the final edition ( $8^{\text {th }}$ edition) of his text 'A Practical Treatise on the Law relating to the Church and Clergy' (1937). He stated that, after the election of a diocesan bishop of the CoE (but not a foreign or a suffragan bishop):

the oath [of homage] and fealty appointed being made to the king by the person so elected, the king is to signify the election to the archbishop, commanding him to confirm the election and to invest and consecrate the person elected. ${ }^{206}$

\footnotetext{
${ }^{198}$ See Coke, n 76, vol 1, 68a (s 91), editorial note to the text (by our law homage was inseparable from fealty, but fealty was not so from homage').

${ }^{199} \mathrm{C}$ Sweet, A Dictionary of English Law (1 $1^{\text {st }}$ ed, 1882)(homage)'homage signified a 'most honourable and humble service of reverence', which every free tenant for an estate in fee simple or in fee tail was bound to perform to his feudal lord; it was so called because in doing homage in ordinary cases the tenant said to his lord 'I become your man [Norman French home] of life and limb'. Homage created an obligation of assistance by the tenant to his lord, and of protection by the lord to his tenant. It was abolished by the Tenures Abolition Act 1660. See also E Jenks, Modern Land Law (1899) p 15, n 2.

${ }^{200}$ See Coke, n 76, vol 1, s 85 (Co Litt 64a). Also, Cheshire, n 192, p 33 and Simpson, n 192, pp 15-6.

${ }^{201}$ See, for the oath of homage, Coke, n 76, vol 1, s 85 (Co Litt 64a) who stated: 'Homage... is the most humble service of reverence, expressing the duty of the tenant to his lord, and the affectionate love and protection of the lord towards his tenant, as hereafter shall appear.' See also Cheshire, n 192, p 33 and Simpson, n 192, pp 15-6.

${ }^{202}$ Halsbury, n 16, vol 29, para 22 item 22 'The ceremonies at the coronation of Elizabeth II were...homage by the peers.'

${ }^{203}$ Sweet, $\mathrm{n} 199$ (fealty) "Fealty is a service which every free tenant (except a tenant in frankalmoign) is in theory bound to perform to his feudal lord. It is therefore an incident to every seignory and is due on every change of the tenancy or the seignory; but it is in practice completely obsolete. The ceremony of fealty consisted in the tenant taking an oath of fidelity to the lord...' Also, 'Etymology - Norman French: From Latin fidelitas, faithfulness.' See generally, Coke, n 76, vol 1, s 91 (67b).

${ }^{204}$ Thus, if the oath of fealty is abolished, this results in no abolition of allegiance (which arises irrespective of an oath in any case). See Coke, n 76, vol 1, s 94 (68b). Also, R Chambers, Treatise on Estates and Tenures (1824), pp 173-5 (difference between liege homage and feudal homage). As to frankalmoign and no fealty, see Coke, n 76, vol 1, s 135 (95a).

${ }^{205}$ Coke, n 76, vol 1, 67b (s 91).

${ }^{206}$ HW Cripps, A Practical Treatise on the Law relating to the Church and Clergy $\left(8^{\text {th }}\right.$ ed, 1937), p 74. See also L Leeder, Ecclesiastical Law Handbook (1997), p 48. Also, Halsbury, n 16, vol 20, para 599 'oaths of homage by archbishops and bishops.' Also, Blackstone, n 101,
} 
This obligation - which also applies to an archbishop of the CoE - is required by the Appointment of Bishops Act 1533, s 4. ${ }^{207}$ Although the reference is to homage and fealty, the latter is subsumed into the former. Thus, the obligation is one of homage.

\section{(b) Conclusion}

Homage was abolished in 1660, save in a ceremonial capacity. Further, fealty is obsolete in practice. Also, there is no good reason to preserve the obligation of homage in the Appointment of Bishops Act 1533, s 4 in the case of some CoE bishops but not others. The wording in that Act, therefore, should be repealed insofar as it refers to the same.

\section{In conclusion, oaths of homage and fealty should be abolished.}

\section{OFFICIAL OATH}

\section{(a) Nature of the Official Oath}

The form of the official oath laid down in the 1868 Act, s 3, is:

I [ ] do swear that I will well and truly serve Her Majesty Queen [Elizabeth II] in the office of [ ]. So help me God.

The officials required to take the official oath are specified in the first part of a schedule to the 1868 Act. ${ }^{208}$ In the case of England, these comprise the following:

- First Lord of the Treasury (i.e. the Prime Minister);

- Chancellor of the Exchequer;

- Lord Chancellor;

- $\quad$ Lord President of the Privy Council;

- $\quad$ Lord Privy Seal;

- Secretaries of State;

- $\quad$ President of the Board of Trade [advisory];

- Lord Steward [of the Household, no longer a political appointment];

- Lord [Great] Chamberlain [a Royal household appointment, no longer a political one];

- Earl Marshal [ceremonial];

- Master of the Horse [ceremonial];

- Chancellor of the Duchy of Lancaster [a sinecure];

- Paymaster General. [obsolete] ${ }^{209}$

In the case of Scotland:

- Lord Keeper of the Great Seal [now transferred to the First Minister];

- Lord Keeper of the Privy Seal; [obsolete]

- Lord Clerk Register; [honorary]

- Advocate General for Scotland (Lord Advocate);

- Lord Justice Clerk. $^{210}$

In the case of Wales:

- $\quad$ First Minister;

\footnotetext{
vol 3, pp 367-8 (indicating the history behind bishops giving homage to the sovereign rather than receiving the gift of a ring and a crozier). For the history behind this, see R Phillimore, Ecclesiastical Law (1873), vol 1, pp 38-44.

${ }^{207}$ Appointment of Bishops Act 1533, s 4 'makyng suche othe [oath of homage] and fealtie only to the Kynges Majestie hys heires and successours as shal be appoynted for the same...' See also 1868 Act, s 14(3).

${ }^{208}$ See also s 5 (persons to take the oath of allegiance and official oath). 'The oath of allegiance and official oath shall be tendered to and taken by each of the officers named in the first part of the schedule annexed hereto as soon as may be after his acceptance of office by the officer, and in the manner in that behalf mentioned in the said first part of the said schedule.'

${ }^{209}$ The oath is tendered by the Clerk of the Privy Council in the presence of the sovereign or as he (she) shall direct. In the original version of the 1868 Act those required to swear an official oath also included the: (a) First Lord of the Admiralty; (b) Chief Commissioner of Works and Public Buildings; (c) President of the Poor Law Board; (d) Commander-in-Chief; and (e) Postmaster General.

${ }^{210}$ The oath is tendered by the President of the Court of Session at a sitting of the court.
} 
- Other Welsh Ministers;

- Counsel General. ${ }^{211}$

Besides the above, the Ministers of the Crown Act 1975 provides for a minister of the Crown to give an official oath as well as an oath of allegiance. ${ }^{212}$ A 'Minister of the Crown' includes:

- Any minister eligible for a salary under the Ministerial and other Salaries Act 1975 (s 1, sch 1, pt 2(2));

- Any minister in charge of a public department of HM's government in the UK who is not a member of the Cabinet and whose office is not specified elsewhere in sch 1;

- The Minister for the Civil Service. ${ }^{213}$

However, instead of an official oath, in all the above cases, an affirmation may be substituted. ${ }^{214}$ The 1868 Act, $\mathrm{s} 12$ also provides for a declaration in other cases:

- Where before the passing of this Act [i.e. 1868] an oath was required to be taken by any person on or as a condition of accepting any employment or office in [HM's] honourable band of Gentlemen at Arms or bodyguard of Yeomen of the Guard, or in any other department of [HM's] household, in such case a declaration of fidelity in office shall be substituted, with the addition (in cases where it seems meet to [HM] by Order in Council to make such addition) of a declaration of secrecy to be observed by the declarant with respect to matters coming within his cognizance by reason of his employment or office.

- Where before the passing of this Act [i.e. 1868] an oath was required to be taken by any person on or as a condition of accepting any office in or under a municipal corporation, or on or as a condition of admission to membership in or participation in the privileges of any municipal corporation, there shall be substituted for such oath, in the case of an office, a declaration that the declarant will faithfully perform the duties of his office, and in the case of admission to membership or participation in the privileges of a municipal corporation, a declaration that the declarant will faithfully demean himself as a member of or participator in the privileges of such corporation.

- Where before the passing of this Act [i.e. 1868] an oath was required to be taken on or as a condition of admission to membership or fellowship or participation in the privileges of any guild, body corporate, society, or company, a declaration to the like effect of such oath shall be substituted: provided, that if any two or more of the members of such guild, body corporate, society, or company, with the concurrence of the majority of the members present and voting at a meeting specially summoned for the purpose, object to any statement contained in such declaration on the ground of its relating to duties which, by reason of change of circumstances have become obsolete, they may appeal to one of [HM's] Principal Secretaries of State to omit such statement, and the decision of such Secretary of State shall be final.

- Where in any case not otherwise provided for by this Act or included within the saving clauses thereof an oath is required to be taken by any person on or as a condition of his accepting any employment or office, a declaration shall be substituted for such oath to the like effect in all respects as such oath.

- The making a declaration in pursuance of this section instead of oath shall in all respects have the same effect as the taking the oath for which such declaration is substituted would have had if this Act had not passed.

The Statutory Declarations Act 1835, s 2 (see 9(e)), also, gives the Treasury power to substitute a statutory declaration where - under legislation relating to specified departments (or under departmental regulations) - an oath, solemn affirmation or affidavit is required to be made or taken. Where a statutory declaration has been substituted, an oath may not be administered. ${ }^{215}$ Thus, in all instances an official oath (i.e. the oath of fidelity) can be replaced by an affirmation (declaration).

\footnotetext{
${ }^{211}$ See Halsbury, n 16, vol 20, para 379 'On appointment as the First Minister, another Welsh Minister or the Counsel General a person must take the official oath...or make the corresponding affirmations'. See also Ibid, para 597. For the Welsh form of oath (or corresponding affirmation) see Welsh Forms of Oaths and Affirmations (Government of Wales Act 2006) Order 2007, SI 2007/2044, arts 2, 3.

${ }^{212}$ Ministers of the Crown Act 1975, sch 1(1) 'The Minister shall take the oath of allegiance, and the official oath, and the Promissory Oaths Act 1868 shall have effect as if the name of the Minister were included in Part I of the Schedule to that Act.'

${ }^{213}$ See also Halsbury, n 16, vol 20, para 160.

${ }^{214}$ Ibid, para 600. See also 1868 Act, s 11, see n 134.

${ }^{215}$ Statutory Declarations Act 1835, s 4.
} 


\section{(b) Abolition of the Official Oath}

The grounds for abolishing the official oath would seem plentiful: viz. (a) it is a statutory creation of 1868; (b) it means little and is opaque. Thus, what does 'I will well and truly serve [the sovereign]' mean ? (c) there is no legal penalty, or punishment, for breaching it (as opposed to refusing to take it) $;{ }^{216}$ (d) the list of those required to give it is quixotic with some offices no longer existing or being of little importance today; (e) in practice, it is often replaced by a declaration in lieu of the oath. ${ }^{217}$ Thus, today, it can be described as a formality that takes up time and money and yet achieves nothing. If the official oath is abolished, should a declaration in lieu be retained? The same grounds for the abolition of the former also apply to the latter. Thus, it should go too.

\section{In conclusion, the official oath (and any declaration in lieu) should be abolished.}

\section{OATH OF ALLEGIANCE}

(a) Nature of Allegiance

The giving of an oath (declaration) of allegiance to the Crown (the sovereign) seems to have commenced in Anglo-Saxon times ${ }^{218}$ and this practice (likely) came from the law of the Franks. ${ }^{219}$

- The oath of allegiance derived from the oaths of homage (which included fealty) and fealty. However, it was different from them, in that the 'liege' in 'allegiance', stressed that the bond of service to the Crown was unconditional - as opposed to homage and fealty which could be given to more than one lord (fealty could also be separate from homage but not the other way around). Thus, allegiance to the Crown (as 'liege lord') took precedence over homage and fealty; 220

- Further, unlike homage and fealty, allegiance was general and not based on any landholding (tenancy). Rather, it was (and always has been) a military oath ${ }^{221}$ like homage. Thus, an oath of allegiance was not (in the past) given by a woman, a girl or a young boy (i.e. one under 12). Only by a man (one, not a slave); ${ }^{222}$

- Further, allegiance was (in time) perceived as a general, overriding, obligation owed by a subject to the Crown. ${ }^{223}$ Thus, Coke noted that every man over the age of 12 was obliged to take the oath of

\footnotetext{
${ }^{216}$ Tyler, n 9, p 258 (writing in 1834) 'All oaths of office are promissory oaths and...the law of England will not suffer a breach of them to be prosecuted as perjury'. He cited Coke, n 76, vol 3, p 74 and noted that: 'experience loudly and plainly tells us, that, in the generality of instances, they [oaths] have very little influence on the conduct of the sworn party.' Cf. Punishment for refusing to take the oath, see the 1868 Act, s 5 (penalty on not taking required oath). If any officer specified in the schedule hereto or any member of the Scottish Executive declines or neglects, when any oath required to be taken by him under this Act or section 84(4) of the Scotland Act 1998 is duly tendered, to take such oath, he shall, if he has already entered on his office, vacate the same, and if he has not entered on the same be disqualified from entering on the same; but no person shall be compelled, in respect of the same appointment to the same office, to take such oath...more times than one.'

${ }^{217}$ Cf. Tyler, n 9, pp 66-8 (in 1834): 'the usual oaths of office, in almost every department, with some exceptions perhaps, I would gladly see abandoned, and without any apprehension of the slightest neglect of duty in consequence...I would say, that no man should ever be called upon even to promise to do what he is bound by the duties of his office to perform; on the contrary, it should in every way be declared, that every man has already promised to do his duty by the very act of accepting an office.' (italics supplied)

${ }^{218}$ Cunningham, n 79, p 102 'In 917 the Lady of Mercia got possession of Derby and all that owed obedience thereto, and in the next year, Leicester, 'and the greater part of the army that owed obedience thereto became subject to her; and the people of York, some having given a pledge and some having bound themselves by an oath that they would be at her command.' Cunningham noted 'Commendations and oaths and military tenure seem here to be taking the place of the loyalty and discipline which had been previously secured by pledges and hostages.'

${ }^{219}$ Plucknett, n 27, p 476.

${ }^{220}$ Holdsworth, $\mathrm{n} 29$, vol 3, p 56 'With the increase in the power of the State, the duty to the king as supreme lord - the duty of allegiance takes precedence over the duty to the lord. William I [1066-89] insisted on the recognition of this principle, and his successors more than maintained his claims.' Holdsworth quotes the Anglo-Saxon Chronicle, in 1087 'he [William I] came to...Salisbury, and there came to him his witan, and all the landowning men of property that were over all England, whose soever men they were, and all bowed down to him and became his men, and swore oaths of fealty [actually, oaths of allegiance] to him that they would be faithful to him against all other men.' See also D Whitelock (ed), The Anglo-Saxon Chronicle (Eyre and Spottiswoode, 1965), p 162.

${ }^{221}$ Ibid, p 54 'Homage is the ceremony which makes the tenant the man of his lord. The oath of fealty is the oath which the tenant swears to be faithful to his lord. 'Fealty', it is said in a Year Book of Edward I's reign [1293, see YB 21, 22 Ed 1 (RS) 240] 'does not make the tenant; for that is only an acknowledgment of the services: but homage makes the tenant.' If a tenant holds several pieces of land of different lords he can only perform unconditional or liege homage, he can only swear unconditional fealty, to one of these lords. The lord is called the liege lord...When homage is done or fealty sworn to the other lords a saving must be made of the duty to the liege lord.'

${ }^{222}$ Ibid. 'Homage... when we first read of it, was a ceremony only performed by the military tenant, and it could not be performed by a woman.'

${ }^{223}$ Pollock \& Maitland, n 4, vol 1, p 299. It was overriding in that it took precedence over any obligation of fealty owed to a lord. The oath of homage in the time of Bracton (c. 1250) contains this saving, see $\mathrm{n} 51$.
} 
allegiance at the court leet (or sheriff's tourn). ${ }^{224}$ This derived from Anglo-Saxon times. However, the clergy (priests) were not obliged to give an oath of allegiance until the Reformation, unless they gave it as part and parcel of an oath of homage. ${ }^{225}$

In medieval times, an oath of allegiance could be rescinded by the giver of the same in various situations. For example, by diffidatio. That is, opposing the royal standard in battle, thereby, rejecting the right of the king to rule. Doing this, laid a person open to the charge of high treason - unless the sovereign renounced his right to be sovereign. ${ }^{226}$ It was also possible for a person to invoke divine law in some circumstances, such as: (i) when asserting the illegitimacy of the asserted sovereign to the throne; or (ii) when asserting the sovereign's incapacity to retain the throne because he had failed to uphold the law. These were similarly hazardous. The concept of allegiance to the Crown, itself, experienced change over time, being allied to a changing jurisprudential analysis as to the right of the sovereign to rule.

- Election. The sovereign in Anglo-Saxon times (following earlier Germanic practice) was elected. This, by means of the oral acclamation (consent) of his people (the 'folk'). ${ }^{227}$ There was no hereditary right;

- $\quad$ Feudal Bond. In English medieval times, the practice had changed. The sovereign was seen as having a feudal relationship (one of homage and fealty) with his subjects, involving mutual rights and obligations, especially that of mutual protection. Acclamation by the people faded, to be replaced by the endorsement of the claimant by the Catholic church and powerful nobles, with there being a degree of hereditary succession. Also, a right to 'passive' resistance if the sovereign failed to uphold the law; ${ }^{228}$

- Divine Right. By the $15^{\text {th }}$ century, a hereditary principle tended to develop. Later, in Stuart times especially in reigns of king James (1603-25) and the ill-fated king Charles I (1625-49) - there developed the concept of a 'divine right' to hereditary rule. However, this was counterbalanced by a right of the subject to exercise 'active' resistance against the sovereign if the same failed to uphold the law; ${ }^{229}$

- $\quad$ Contract. The jurisprudential analysis of a 'divine right' to rule was, itself, displaced by a 'contract' theory. This, in particular, after the 'Glorious' Revolution of 1688 (where there was also a marked tendency to read back a contract theory into the past). ${ }^{230}$

The form of the oath of allegiance tended to reflect such transitions and it changed over time. ${ }^{231}$ In respect of the oath of allegiance today, Halsbury states:

Persons entering on certain offices are required by law to take the oath of allegiance, or an affirmation or declaration in lieu of the oath, in the manner provided by statute, and aliens becoming naturalised are also required to take the oath. The taking of the statutory oath does not add to the natural duty of a subject, who is in all cases bound as though he had taken the oath. ${ }^{232}$ Refusal to take the oath in certain

\footnotetext{
${ }^{224}$ Coke, n 76, vol 1, 68b (s 94) noted by Burn, n 98, vol 3, p 532.

${ }^{225}$ See M Hale, History of the Pleas of the Crown (1736), vol 1, pp 71-2 cited by Burn, n 98, vol 3, p 532 who noted 'But the clergy were not obliged to take the oath of allegiance till the Reformation, any further than doing homage to the king for the lands held of him in right of the church.'

${ }^{226}$ See generally GS McBain, Abolishing the Crime of Treason (2007) 81 ALJ, pp 94-134, especially pp 97-8.

${ }^{227}$ This may be also seen in the oral acclamation of William I (1066-87) when crowned after the Norman Conquest 1066. See also Downer, n 48, p 277 (Coronation Charter of Henry I (1100-35): 'Be it known to you that, by the mercy of God and with the full consent of the barons [freemen] of the whole realm of England, I have been crowned king of the afore-mentioned realm.'

${ }^{228}$ As Kern noted, n 77, p 88 'The English barons in the fourteenth century gave this idea [one of fealty owed to the sovereign] a modern formulation when they stated that their oath of fealty was due to the Crown rather than to the actual wearer of it - that is, to the unchangeable symbol of lawful magistracy rather than to the individual caprice of a particular monarch.'

${ }^{229}$ This may be seen in the reign of Charles I (1625-49) where Parliament, at first, opposed him on the basis of his being mislead by deceiving counsellors (advisers) - such as the Duke of Buckingham (George Villiers, 1592-1628) - and,then, on the basis of his own high treason in seeking to undermine Parliament and the rule of law (although the assertion of high treason did not have a profound legal basis since it had previously always been founded on treason against the sovereign and not by him).

${ }^{230}$ This is (well) traced by Kern, see n 77, especially his summary, pp 135-43.

${ }^{231}$ That from the time of the 'Glorious' Revolution was laid down in the Bill of Rights 1688 'I [X], do sincerely promise and swear, that I will be faithful and bear true allegiance to their Majesties king William and queen Mary. So help me God.' Noted by Keir, n 77, p 270 (see also the Claim of Right Act 1689 (Scots) with similar wording). For the oath of supremacy, see Keir, n 77, pp 80-1, 83-6, 106, 108, 251, 270 $\& 431$.

${ }^{232} R v$ Arrowsmith [1975] 1 AE 463, 469 per Lawton LJ 'A man owes allegiance to the Crown, whether he has taken the oath of allegiance or not.' See also McBain, n 226, p 121. Even if an oath of allegiance is not given, it is implied. Coke, n 76, vol 2, p 121 'all subjects... are firmly bounden to their allegiance, as if they had taken the oath... and the taking of the corporal oath, is but an outward declaration of the same'.
} 
cases, however, entails disqualification from holding office, or vacation of the office if the person has already entered upon it, ${ }^{233}$ whilst in the case of clerical orders and preferments the taking of the oath is a condition precedent to ordination, or to institution or collation or to the granting of a licence in the case of benefices.

As regards peers and members of Parliament, sitting or voting in either House without having first taken and subscribed the oath entails a fine [of £500] in certain cases. Where an oath of allegiance has been duly administered and taken, the fact that the person to whom it was administered had at the time of taking the oath no religious belief does not affect the validity of the oath. ${ }^{234}$ (italics supplied)

However, in all cases where an oath of allegiance is required, an affirmation may be substituted, as in the case of the official oath (see above). ${ }^{235}$ The form of the oath of allegiance laid down in the 1868 Act, s 2 provides:

I [ ] do swear that I will be faithful and bear true allegiance ${ }^{236}$ to Her Majesty [ ], her heirs and successors, according to law. So help me God.

The officials required to take the oath of allegiance are specified in the second part of a schedule to the Act and in other legislation. ${ }^{237}$ They comprise the:

- $\quad$ Lord Chief Justice;

- $\quad$ President and Deputy President of the Supreme Court;

- Judges of the Supreme Court;

- Master of the Rolls;

- $\quad$ President of the Family Division;

- Chancellor of the High Court;

- Lords Justices of Appeal;

- Puisne Judges of the High Court;

- Circuit Judges and Recorders;

- Master of the Queen's Bench Division;

- Master of the Chancery Division;

- Registrar in Bankruptcy of the High Court;

- Taxing Master of the Senior Courts

- Admiralty Registrar;

- $\quad$ Recorder of London;

- Justice of the Peace (JP's);

- District Judges (inc. a district judge of the principal registry of the Family Division).

In the case of Scotland, the:

- Lord Justice-General and President of the Court of Session;

\footnotetext{
${ }^{233} 1868$ Act, s 7 (penalty on not taking required oath) 'If any officer specified in the schedule hereto or any member of the Scottish Executive declines or neglects, when any oath required to be taken by him under this Act or section 84(4) of the Scotland Act 1998 is duly tendered, to take such oath, he shall, if he has already entered on his office, vacate the same, and if he has not entered on the same be disqualified from entering on the same; but no person shall be compelled, in respect of the same appointment to the same office, to take such oath...more times than one.' The same applies for the making of a declaration in lieu, Ibid, s 13.

${ }^{234}$ Halsbury, n 16, vol 20, para 40.

${ }^{235}$ See, in particular, the Oaths Act 1978, s 5 (persons to take the oath of allegiance and official oath). 'The oath of allegiance and official oath shall be tendered to and taken by each of the officers named in the first part of the schedule annexed hereto as soon as may be after his acceptance of office by the officer, and in the manner in that behalf mentioned in the said first part of the said schedule.'

${ }^{236}$ The oath derives from the use of the word 'swear.' The word 'faithful' (likely, the word 'loyal' is a synonym) reflects the oath of fealty (faithfulness) from which the oath of allegiance derived. The word 'true' (likely) is a synonym for 'unconditional'. Thus, allegiance is owed to the sovereign, regardless of any oaths of homage or fealty given to other lords.

${ }^{237}$ See also 1868 Act, s 6 (persons to take the oath of allegiance and judicial oath) 'The oath of allegiance and judicial oath shall be taken by each of the officers named in the second part of the said schedule hereto as soon as may be after his acceptance of office.' Those formerly included also comprised: (a) Lord Chancellor; (b) Chief Justice of the Common Pleas; (c) Chief Baron of the Exchequer; (d) Lord Justices of the Court of Appeal in Chancery; (e) Vice Chancellors; (f) Puisne Justices of the Queen's Bench and the Common Pleas and Puisne Barons of the Exchequer; (g) Judge of the Admiralty Court; (h) Judge of the Probate Court. As to before whom the oath of allegiance is sworn, see Halsbury, n 16, vol 20, para 597.
} 
- $\quad$ Lord Justice Clerk; ${ }^{238}$

- Judges (and temporary judges) of the Court of Session;

- Temporary judges of the High Court of Justiciary;

- Sheriff principal of Sheriffdoms;

- Sheriffs and summary sheriffs (inc. those part-time);

- JP's.

In the case of Wales, the:

- First Minister and other Welsh Ministers; ${ }^{239}$

- Counsel General;

- Deputy Welsh Minister; ${ }^{240}$

- Other Assembly Members. ${ }^{241}$

An oath of allegiance is also given by: (a) priests of the CoE; (b) members of the armed forces; (c) privy counsellors; (d) MP's and peers; (e) public notaries, (f) aliens, on naturalisation. Boland and Sayer on Oaths and Affirmations, the standard text, summarised the position in 1961:

Certain officers of state have to take the oath of allegiance and official oath on assuming office, the Lord Chancellor being one of them. The enactment [the 1868 Act] goes on to provide that the oath of allegiance and judicial oath shall be taken by certain of the judiciary, including the Lord Chancellor, Lord Chief Justice, Master of the Rolls, puisne judges of the Queen's Bench, official referees, county court judges and Masters of the Court of Protection and various other enactments contain a similar direction as regards judicial offices.

The oath of allegiance alone has to be taken by members of both Houses of Parliament on taking their seats, and by certain other persons on entering office or acquiring a special status. From a practical point of view, the most important example is that of an alien on becoming a naturalised British subject. $^{242}$ (italics supplied)

However, today, the above references to various to legal officials no longer include some of them.

\section{(b) Abolishing the Oath of Allegiance}

The oath, at base, is a military oath. One of the subject rendering military assistance (aid) to the sovereign, in return for protection. ${ }^{243}$ Further, giving an oath of allegiance has nothing to do with whether a person, legally, owes allegiance to the sovereign. A person can owe allegiance to the same regardless of whether an oath has been given. And - although an oath may be given - later, it can be held that, as a matter of law, no allegiance was owed.

- Thus, since the oath of allegiance is (at base) a military oath, there is little good legal reason for it being required of $\mathrm{CoE}$ priests. Or of notaries (but not solicitors or barristers). Or, of some judges (but not all). Further, the oath was only required for Privy Council members, MP's and peers by Tudor legislation. Therefore, consideration should be given as to all these persons being dispensed from the need to give it. They will still owe allegiance in any case (if British subjects or naturalised persons or in certain other cases); ${ }^{244}$

\footnotetext{
${ }^{238}$ The oath is tendered by the President of the Court of Session at a sitting of the court.

${ }^{239}$ Halsbury, n 16, vol 20, para 379 (and para 598, as to before whom they are taken) See also Ibid, vol 20, para 597 'The First Minister of Wales and other Welsh Ministers must take the oath of allegiance and the official oath....and members of the Welsh Assembly are also required to take the oath of allegiance.'

${ }^{240} \mathrm{Ibid}$ (as well as for the Counsel General). For the Welsh form of oath (or corresponding affirmation) see Welsh Forms of Oaths and Affirmations (Government of Wales Act 2006) Order 2007, SI 2007/2044, arts 2, 3.

${ }^{241}$ Halsbury, n 16, vol 20, para 362 'An Assembly member must take the oath of allegiance (or make the corresponding affirmation) as soon as is reasonably practicable after being returned as an Assembly member, whether for the first time or subsequently.' See also Government of Wales Act 2006, s 23 (1).

${ }^{242}$ Fell \& Keats, n 15, p 47. This text, p ix (Preface), noted that the standard texts before it were Ford on Oaths (1876-1910), see n 15 and Stringer on Oaths and Affirmations (1889-1927), see n 15.

${ }^{243}$ Calvin's Case (1608) 7 Co Rep 1a at 5a 'Protectio trahit subjectionem, et subjectio protectionem'. Ibid, 5a '[just] as the subject owes to the king his true and faithful ligeance and obedience, so the sovereign is to govern and protect his subjects.' See also McBain, $\mathrm{n} 226$, $\mathrm{p} 121$.

${ }^{244}$ See McBain, n 226, pp 121-2.
} 
- Other grounds may be adduced - as with the official oath - for abolishing it: (a) the wording is a statutory creation of 1868; (b) the wording means little today, being opaque and archaic; thus, what does ' $I$ will be faithful and bear true allegiance to [the sovereign]' mean $? ;{ }^{245}$ (c) there is no punishment/penalty for breaching it (cf. for refusing to give it); (d) the list of those required to give it is quixotic; (e) in practice, this oath is (very often) replaced by a declaration (affirmation) in lieu.

In short, today, this oath can be described as a formality that takes up time and money and yet achieves nothing. Thus, consideration should be given to abolishing the oath and wholly replacing it with a declaration instead. One employing more modern wording. Further, such a declaration (being one of military assistance) should only now be sought from, it is asserted: (a) members of the armed forces on enlistment; and (b) foreign persons, on naturalisation.

In conclusion, the oath of allegiance should be wholly replaced with a declaration of allegiance. One with more modern wording. One only required to be given by: (a) members of the armed forces and; (b) aliens on naturalisation.

\section{JUDICIAL OATH}

(a) Form of Oath

The form of the judicial oath laid down in the 1868 Act, s 2 provides:

I [ ] do swear that I will well and truly serve our Sovereign Lady Queen [Elizabeth II] in the office of [ ], and I will do right to all manner of people after the laws and usages of this realm, without fear or favour, affection or ill will. So help me God.

The officials required to take the judicial oath are specified in a schedule to the 1868 Act and they are the same as those relating to the oath of allegiance (see 21), as Halsbury notes:

As soon as may be after their acceptance of office, the senior executive officers of state and members of the judiciary as specified by statute must take the oath of allegiance and [the] official or judicial oath, in the form and manner prescribed.

Such persons include [for the judicial oath] the Recorder of London, and [JP's]; the district judges (including a district judge of the principal registry of the Family Division), the Master of the Queen's Bench Division, the Master of the Chancery Division, the Registrar in Bankruptcy of the High Court, the Taxing Master of the Senior Courts and the Admiralty Registrar; and the Lord Chief Justice, the Master of the Rolls, the President of the Queen's Bench Division, the President of the Family Division, the Chancellor of the High Court, the Lords Justices of Appeal and puisne judges of the High Court. It also includes the President and Deputy President of the Supreme Court and judges of the Supreme Court; and circuit judges and recorders. ${ }^{246}$

The form of the judicial oath of the Lord Chancellor is slightly different. It provides:

I [ ] do swear that in the office of Lord High Chancellor of Great Britain I will respect the rule of law, defend the independence of the judiciary and discharge my duty to ensure the provision of resources for the efficient and effective support of the courts for which I am responsible. ${ }^{247}$

(b) Abolishing the Oath

The grounds for abolishing the judicial oath are the same as in respect of the official oath. Further, much of the wording of the judicial oath has little import.

- Thus, what does 'I will well and truly serve' mean ? Probably, the word 'truly' means loyally - not 'unconditionally' (as opposed to the word 'true' in the oath of allegiance);

- What does 'I will do right to all manner of people after the laws and usages of this realm, without fear or favour, affection or ill will' mean ? Probably, the word 'right' refers to justice - with the general

\footnotetext{
${ }^{245}$ Better to say, 'I declare allegiance to [the sovereign]'. This is more intelligible since oaths of fealty and homage are legally obsolete today (although still given as a matter of ceremony in certain cases). Thus, the words 'faithful' (reflecting the oath of fidelity) and 'true' (reflecting the unconditionality of the allegiance, see text to $\mathrm{n} 220$ ) are no longer required.

${ }^{246}$ Halsbury, n 16, vol 20, para 597 and 1868 Act, s 6 ((persons to take the oath of allegiance and judicial oath) 'The oath of allegiance and judicial oath shall be taken by each of the officers named in the second part of the said schedule hereto as soon as may be after his acceptance of office.'(italics supplied)

${ }^{247}$ For the form of the oath in the $17^{\text {th }}$ century, see Coke, n 76, vol 4, p 88.
} 
purport of the oath comprising a declaration to administer justice impartially without regard to the class of the person and not to accept bribes etc. ${ }^{248}$

However, the fact that a judicial oath is not given by all judges does not mean that they are absolved from such obligations. For the same reasons given for the abolition of the official oath, the judicial oath (which is a form of official oath) should be abolished.

\section{In conclusion, the judicial oath (and any declaration (affirmation) in lieu) should be abolished.}

\section{PRIVY COUNSELLOR'S OATH}

Halsbury states:

Privy counsellors are required to take the privy counsellor's oath or an affirmation in lieu of that oath. The substance of the oath is: (1) to be a true and faithful servant of the Crown; (2) not to countenance any word or deed against the monarch, but to withstand the same to the utmost of his power, and to reveal it to the monarch or the Privy Council; (3) to declare his true and faithful opinion upon all matters before the Privy Council; (4) to keep secret all matters revealed or treated of in the Privy Council; (5) not to reveal matters so treated of touching any of his colleagues with the consent of the monarch or the Privy Council; (6) to bear faith and allegiance to the Crown, and to defend its jurisdiction and powers against all foreign princes, persons, prelates, states or potentates; and (7) generally to act as true and faithful servants of the Crown. ${ }^{249}$

Presently, the form of the privy counsellor's oath is:

1. You do swear by Almighty God to be a true and faithful servant unto the Queen's Majesty, as one of [HM's] Privy Council.

2. You will not know or understand of any manner of thing to be attempted, done, or spoken against [HM's] person, honour, crown, or dignity royal, but you will let and withstand the same to the uttermost of your power, and either cause it to be revealed to [HM] herself, or to such of her Privy Council as shall advertise [HM] of the same.

3. You will, in all things to be moved, treated, and debated in Council, faithfully and truly declare your mind and opinion, according to your heart and conscience;

4. And you will keep secret all matters committed and revealed unto you, or that shall be treated of secretly in Council.

5. And if any of the said treaties or counsels shall touch any of the counsellors, you will not reveal it unto him, but will keep the same until such time as, by the consent of [HM], or of the Council, publication shall be made thereof.

6. You will to your uttermost bear faith and allegiance unto the Queen's Majesty; and will assist and defend all jurisdictions, pre-eminences, and authorities, granted to [HM], and annexed to the Crown by Acts of Parliament, or otherwise, against all foreign princes, persons, prelates, states, or potentates.

7. And generally in all things you will do as a faithful and true servant ought to do to [HM]. So help you God. ${ }^{250}$

Also, privy counsellors take the oath of allegiance in the form set out in the 1868 Act (see 21). ${ }^{251}$ It may be seen that the privy councillor's oath contains material similar to an official oath (oath of fidelity), see sub-oaths 1-3 and 7 above. Also, material similar to the oath of allegiance, see sub-oath 7 above. The remainder relates to maintaining things spoken at meetings, secret, see sub-oaths $3 \& 4$ above. As to form of this oath, it being a religious affirmation, consideration should be given to the oath of the Privy Councillor being replaced with a

\footnotetext{
${ }^{248}$ See the old judges oath of 1344 (20 Edw III st 4) 'ye shall do equal law, and execution of right, to all his subjects, rich, and poor, without having regard to their person.' See also Coke, n 76, vol 3, 146, 224 and vol 1, 11a, n 5.

${ }^{249}$ Halsbury, n 16, vol 20, para 270. For that of the privy counsellor in the $17^{\text {th }}$ century, see Coke, n 76, vol 4, p 54 (he also indicated the form of the Lord Privy Seal's oath. Ibid, p 55). It seems that members of the Royal family, who are privy councillors, are not required to take the privy councillors oath, see Halsbury, n 16, vol 20, para 270.

${ }^{250}$ Ibid. See also 1867 Report, n 122, p 84 where a form of declaration was recommended in 1867 in place of the oath. An oath of secrecy was not restricted to privy councillors, e.g. common councilmen of the City of London were obliged to swear an oath '...that all secrets that be spoken or said in the common council, the which ought to be kept secret, ye shall in no wise disclose', see Pulling, $\mathrm{n} 125$, $\mathrm{p} 41$.

${ }^{251}$ See also Halsbury, n 16, vol 20, para 271.'Privy counsellors are called to office by the monarch's invitation, and after taking the oath of allegiance and the privy counsellor's oath, or an affirmation in lieu of either of those oaths, their names are inscribed in the Privy Council book.'
} 
declaration. One which also excludes those sub-oaths which comprise official oaths and the oath of allegiance not least, since there is no punishment or penalty for breach (e.g. it is not high treason to breach one's oath of allegiance, per se). Thus, the Privy Councillor's oath should be reduced to one dealing with secrecy (and the wording be modernised). Further, perhaps, the oath should be written (i.e. the councillors sign a book) in order to save time and administration.

In conclusion, the oath of a Privy Councillor should become a declaration instead of an oath. And it should be reduced to keeping secret matters discussed at meetings. It would also seem useful if the oath was in writing and it was signed by each member (perhaps, at the same time as they inscribe the Privy Council's book).

\section{PARLIAMENTARY OATH}

An Act for Administering the Oath of Allegiance 1609 (repealed) provided that no member of Parliament should be permitted to enter the same until he had taken an oath of obedience (including one of allegiance). ${ }^{252}$ Further, the Test Act 1678 (repealed) provided that no member of Parliament should vote (or sit) until he had taken the oath of allegiance, supremacy and abjuration. Also, until he had subscribed (and repeated) the declaration against transubstantiation. ${ }^{253}$ Today, the Parliamentary Oaths Act 1866, s 1, requires MP's and peers to take an oath of allegiance (or to give an affirmation in lieu). ${ }^{254}$ As for the time and manner of giving such an oath, s 3 states:

The oath hereby appointed shall in every Parliament be solemnly and publicly made and subscribed by every member of the House of Peers at the table in the middle of the said House before he takes his place in the said House, and whilst a full House of Peers is there with their Speaker in his place, and by every member of the House of Commons at the table in the middle of the said House, and whilst a full House of Commons is there duly sitting, with their Speaker in his chair, at such hours and according to such regulations as each House may by its standing orders direct.

Section 5 indicates the penalty for failing to take an oath:

If any member of the House of Peers votes by himself or his proxy in the House of Peers, or sits as a peer during any debate in the said House without having made and subscribed the oath hereby appointed, he shall for every such offence be subject to a penalty of [£500], to be recovered by action in the High Court; and if any member of the House of Commons votes as such in the said House, or sits during any debate after the Speaker has been chosen, without having made and subscribed the oath hereby appointed, he shall be subject to a like penalty for every such offence, and in addition to such penalty his seat shall be vacated in the same manner as if he were dead. ${ }^{255}$

The requirement to take the oath of allegiance (a military form of oath) in Stuart times should be viewed against the background of the struggle for power between Parliament and the Crown. As previously noted (21(b)), it is asserted that such a requirement, today, is unnecessary and consideration should be given to dispensing with it, both in the case of peers and MP's.

In conclusion, consideration should be given to dispensing with the oath of allegiance (which is a military oath) for MP's and peers.

\section{CHURCH OF ENGLAND OATHS}

As previously noted, diocesan bishops and archbishops make homage to the Crown as part of their consecration, pursuant to the Appointment of Bishops Act 1533 (see 19(a)). It has been asserted that such should be abolished, since making (paying) homage has been, generally, abolished since 1660. Those entering into holy orders (that is, becoming priests) also give an oath of: (a) allegiance; (b) canonical obedience. The former is required by legislation (the Clerical Subscription Act 1865), the latter provided in a Canon of the CoE. As to these:

\footnotetext{
$2527 \mathrm{Jac}$ 1, c 6 (rep 1846). For the oath see 3 Jac 1, c 4 (1605, rep 1846). Crabb, n 160, p 503 'Another statute [7 Jac 1 c 6], which had particular reference to the papists, but which was of a general nature, was that which required all peers, privy councillors, judges, and other officers, before they entered upon the discharge of their several duties, as also all members of the House of Commons, before they took their seats, to take the oaths of allegiance and supremacy.' See also, generally, Condren, n 15, ch 13.

${ }^{253} 30$ Car 2 st 2 (rep 1866) and 1 Geo 1 st 2 c 13 (rep 1872). See also Plucknett, n 27, p 427. For the position by 1842 , see HJ Stephen, New Commentaries on the Laws of England (1842), vol 2, pp 366-7.

254 The form of the oath was laid down in the 1868 Act.

${ }^{255}$ This penalty comes from the Test Act 1678. See also Plucknett, n 27, p 427.
} 


\section{(a) Clerical Subscription Act $\mathbf{1 8 6 5}$}

Section 4 (subscription and oaths on ordination) states:

Every person about to be ordained priest or deacon shall, before ordination, in the presence of the archbishop or bishop by whom he is about to be ordained, at such time as he may appoint...take and subscribe the oath of allegiance [and supremacy - which words are now redundant]. ${ }^{256}$

Other sections also provide:

- $\quad$ S 5 (subscription and oath on institution to benefice, or licence to perpetual curacy, \&c.) 'Every person about to be instituted or collated to any benefice, or to be licensed to any perpetual curacy, lectureship, or preachership, shall, before institution or collation is made or licence granted... take the said oath of allegiance and supremacy, in the presence of the archbishop or bishop by whom he is to be instituted, collated, or licensed, or the commissary of such archbishop or bishop.';

- S 9 (no other declaration or oaths than those required by the Act to be enforced.) 'Subject as hereinafter mentioned, no person shall, on or as a consequence of ordination, or on or as a consequence of being licensed to any stipendiary curacy, or on or as a consequence of being presented, instituted, collated, elected, or licensed to any benefice with cure of souls, perpetual curacy, lectureship, or preachership, be required to make any subscription or declaration, or take any oath, other than such subscriptions, declarations, and oath as are required by this Act or by [a] Canon of the General Synod. ${ }^{257}$

- $\mathrm{S} 12$ (nothing to affect oath of canonical obedience to bishop, \&c.) 'Nothing in this Act contained shall extend to or affect the oath of canonical obedience to the bishop, or the oath of due obedience to the archbishop taken by bishops on consecration.'

This Act does not extend to the islands of Guernsey, Jersey, Alderney and Sark; nor to the Isle of Man (s 13). Further, the oath of allegiance is not required of bishops consecrated to officiate in any foreign State; nor of overseas clergyman, see Canon $\mathrm{C} 13$ (of the oath of allegiance), which also provides for an affirmation in lieu of an oath (it follows the form in the $1868 \mathrm{Act}$ ). ${ }^{258}$ As previously indicated, this requirement in respect of an oath of allegiance was a result of the Reformation, an oath formerly being given to the Pope by priests of the Catholic church in England. However, being a military oath, the oath of allegiance is not really appropriate for priests (and was not intended to be given by females in times past).

\section{(b) Oath of Canonical Obedience}

Canon C14 (of the oaths of obedience) states:

1. Every person whose election to any bishopric is to be confirmed, or who is to be consecrated bishop or translated to any bishopric, or suffragan bishopric, shall first take the oath of due obedience to the archbishop and to the metropolitical Church of the Province wherein he is to exercise the episcopal office in the form and manner prescribed in and by the Ordinal.

2. Either archbishop consecrating any person to exercise episcopal functions elsewhere than in England may dispense with the said oath.

3. Every person who is to be ordained priest or deacon, or to be instituted to any benefice, or to be licensed either to any lectureship, preachership, or stipendiary curacy, or to serve in any place, shall first take the oath of canonical obedience to the bishop of the diocese by whom he is to be ordained, instituted, or licensed, in the presence of the said bishop or his commissary,

\footnotetext{
${ }^{256}$ The words 'of supremacy' are redundant since the oath now given is that set out in the 1868 Act.

${ }^{257}$ The Act, s 11, states generally: (oaths not to be administered during ordination or consecration services.) 'No oath shall be administered during the service for the ordering of deacons, or during the service for the ordering of priests, or during the service for the consecration of archbishops and bishops.'

${ }^{258}$ 1. Every person whose election to any archbishopric or bishopric is to be confirmed, or who is to be consecrated or translated to any suffragan bishopric, or to be ordained priest or deacon, or to be instituted, installed, licensed or admitted to any office in the [CoE] or otherwise serve in any place, shall first, in the presence of the archbishop or bishop by whom his election to such archbishopric or bishopric is to be confirmed, or in whose province such suffragan bishopric is situate, or by whom he is to be ordained, instituted, or admitted, or of the commissary of such archbishop or bishop, take the oath of allegiance in the form following: I, A B, do swear that I will be faithful and bear true allegiance to Her Majesty Queen Elizabeth II, her heirs and successors, according to law: So help me God.' 2. 'The aforesaid oath of allegiance shall not be required to be taken: (a) by any subject or citizen of a foreign state whom either archbishop, calling to assist him such bishops as he thinks fit, shall consecrate to officiate as a bishop in any foreign state; or (b) by any overseas clergyman to whom [s] 2 of the Overseas and other Clergy (Ministry and Ordination) Measure 1967 applies or any other person ordained under [s] 5 of that Ministry for Ministry reasons, if the bishop dispenses with the said oath.' See also M Hill, Ecclesiastical Law (2018), pp 320-1 and The Canon Law of the Church of England, being the Report of the Archbishops' Commission on Canon Law (1947)(the 'Archbishops' Commission'), p 158.
} 
and in the form following: I, A B, do swear by Almighty God that I will pay true and canonical obedience to the Lord Bishop of $C$ and his successors in all things lawful and honest. So help me God. ${ }^{259}$

This oath may be dispensed with for episcopal functions outside England (see 2 above). Also, it may be replaced with an affirmation. ${ }^{260}$ Further, given Christ's injunction against oaths - and the fact that they are not legally binding - it may be apposite today to transmute this oath into a written (simplified) declaration. ${ }^{261}$ Also, to combine it with the declaration of assent laid down in Canon C15 (making the same written and simplified - to save time and add to clarity). It may also be noted that the present canonical oath does not actually mean what it says since, in Long $v$ Bishop of Capetown (1863), the Judicial Committee of the Privy Council (Lord Kingsdown giving the judgment) stated that:

the oath of canonical obedience does not mean that the clergyman will obey all the commands of the bishop against [i.e. in respect of ] which there is no law, but that he will obey all such commands as the bishop by law is authorised to impose. ${ }^{262}$

In conclusion, the statutory obligation of CoE diocesan bishops (and the archbishops of Canterbury and York) to pay homage should be repealed, since homage was abolished for all others in 1660 (save for ceremonial purposes). Any requirement of CoE priests to give an oath of allegiance (a military oath) should be dispensed with. And, the oath of canonical obedience could be combined (as a declaration) with the declaration of assent in canon $C 15$.

\section{PUBLIC NOTARY'S OATH}

A public notary, prior to admission, is required to give an oath required by the Public Notaries Act 1843, s 7, which states:

Every person to be admitted and enrolled a public notary shall, before a faculty is granted to him authorizing him to practice as such...make oath before the said master of the faculties, his surrogate or other proper officer, in substance and to the effect following: I A.B. do swear, that I will faithfully exercise the office of a public notary; I will faithfully make contracts or instruments for or between any party or parties requiring the same, and I will not add or diminish any thing without the knowledge and consent of such party or parties that may alter the substance of the fact; I will not make or attest any act, contract, or instrument in which I shall know there is violence or fraud; and in all things I will act uprightly and justly in the business of a public notary, according to the best of my skill and ability.

However, no such oath (or declaration) is required in respect of an ecclesiastical notary or a European Economic Area notary. ${ }^{263}$ Further, there is no such oath (or declaration) required for barristers or solicitors. Thus, this oath - which is similar to an official oath - should be dispensed with.

\section{In conclusion, the Public Notaries Act 1843, s 7 should be repealed.}

\section{OATHS IN LEGAL PROCEEDINGS}

In criminal proceedings, the oath of a juror is old. Older than that required of a witness, since the juror often included this role. ${ }^{264}$ However, over time, the form of these oaths has became archaic and opaque. As to these:

\section{(a) Juror}

The standard work on oaths and affirmations in 1961, Fell and Keats (who edited the second edition of Boland and Sayer on Oaths and Affirmations), noted the form of oath given by jurors individually in criminal proceedings:

\footnotetext{
${ }^{259}$ See also, Archbishops' Commission, n 258, p 159.

${ }^{260}$ Canon C14(4) 'I do solemnly, sincerely and truly declare and affirm that I will pay true and canonical obedience to the Lord Bishop of C and his successors in all things lawful and honest.' The words in italics, actually, add nothing and an 'affirmation' is a synonym for a 'declaration.' This wording originated from the 1868 Act, s 11 (rep), see also n 134.

${ }^{261}$ e.g. 'I declare canonical obedience to the Lord Bishop of C (and his successors) in all things lawfully imposed.'

${ }^{262}$ Privy Council Reports NS, vol 1, p 465.

${ }^{263}$ Halsbury, n 16, vol 66, para 1004 (s 7 is also prospectively repealed in relation to the Isle of Man).

${ }^{264}$ Pollock \& Maitland, n 4, vol 2, p 601 'Besides the oaths of litigants and their oath-helpers, the law also knew the oath of witnesses; but apparently in the oldest period it did not often have recourse to this mode of proof, and the oaths which those witnesses proferred were radically different from the sworn testimony that is now-a-days given in our courts. For one thing, it seems to have been a general rule that no one could be compelled, or even suffered, to testify to a fact, unless when the fact happened he was solemnly 'taken to witness.' Secondly, when the witness was adduced, he came merely in order that he might swear to a set formula. His was no promissory oath to tell the truth in answer to questions, but an assertory oath.'
} 
Members of the jury please stand up to be sworn. When your name is called, hold the Testament up in your right hand and read the oath aloud from the card. When you have taken the oath please sit down. I swear by Almighty God that I will faithfully try the several issues joined between our sovereign lady the Queen and the prisoner at the bar and give a true verdict according to the evidence. ${ }^{265}$

This legal text, also, noted that a collective oath might be made by the jurors (on a trial on indictment for felony or misdemeanour). Thus, the whole of the jury (or any two or more) might be sworn together. ${ }^{266}$ Further, there were various variants - including the oath given by the court bailiff looking after the jurors and any interpreter. ${ }^{267}$ Today, a juror gives the following oath (or affirmation) - assuming no other changes according to religion, age or whether mute etc:

I swear by Almighty God that I will faithfully try the defendant and give a true verdict according to the evidence. $^{268}$

The problem with such an oath is that it is a religious affirmation and, thus, not appropriate in a number of instances. Further, the words 'faithfully try' and 'give a true verdict' mean very little to non-lawyers - and, indeed, to many lawyers. 'Faithfully' harks back to the old oaths of homage and fealty (also, the official oath), in which a person declares that they will carry out their service obligations to their lord, in a loyal and honest manner. However, today, the essence of this oath has nothing to do really with loyal service to the Crown (the Queen) as over lord. Rather, it is a declaration by a person that they will be impartial and honest (that is, not be corrupt - such as accepting bribes to influence their verdict etc).

\section{(b) Witness}

Fell and Keats (see above) in 1961 also noted the form of oath given by a witness:

I swear by Almighty God that I will true answer make to all such questions as shall be asked me, without favour or affection to either party, and therein I will speak the truth, the whole truth, and nothing but the truth. ${ }^{269}$

Today, the witness oath is:

I swear by Almighty God that the evidence I shall give shall be the truth, the whole truth and nothing but the truth. 270

The words 'the truth, the whole truth and nothing but the truth' have a sonorous ring to them, like the AngloSaxon triple oath (for example, the thrice 'nay' (no)). Also, they hark back to the time when a mistake in giving the (verbal) oath (called, a miskenning) was - in Anglo-Saxon and early medieval times - fatal. This, on the basis that God was revealing, by means of the mistake, that the person was not being honest (much like the ordeal). In those times, the form of the oath was very rigid. ${ }^{271}$ Also, repetition - and the weight to be attached to each person's oath - was an essential part of the process. ${ }^{272}$ However, today, this triple repetition as to the truth is tautologous and unnecessary.

\footnotetext{
${ }^{265}$ Fell \& Keats, n 15, p 118 who noted 'Revised in accordance with Practice Note vide [1957] 1 All E.R. at p 290.'

${ }^{266} \mathrm{Ibid}$. The oath was 'You shall faithfully try the issues joined between our Sovereign Lady the Queen and the prisoner at the bar and give a true verdict according to the evidence. So help you God.'

${ }^{267}$ Ibid, pp 118-24.

${ }^{268}$ viz. 'I solemnly, sincerely and truly honestly declare and affirm that I will faithfully try the defendant and give a true verdict according to the evidence.' The words in italics mean little. Further, a 'declaration' and an 'affirmation' are synonyms. This wording originated from the 1868 Act, s 11 (rep), see also no 134.

${ }^{269}$ Fell \& Keats, n 15, p 126. The practice of adding 'So help me God' was declared unnecessary in 1910, see Stringer ( $3^{\text {rd }}$ ed, 1910), n 15, p 136. This triple affirmation, likely, derived from the Bible (denials and affirmations of St Peter).

${ }^{270}$ There are some variants. The affirmation is 'I do solemnly and sincerely and truly declare and affirm that the evidence I shall give shall be the truth, the whole truth and nothing but the truth.'

${ }^{271}$ Pollock \& Maitland, n 4, vol 1, p 38 'As to procedure, the forms were sometimes complicated, always stiff and unbending. Mistakes in form were probably fatal at every stage.' See Ibid, $\mathrm{p} 90, \mathrm{n} 1$, for the 'unbroken oath' (sacramento non fracto).

${ }^{272}$ M Deansley, The Pre-Conquest Church in England (London, $2^{\text {nd }}$ ed, 1963), p 331. 'The method of determining guilt actually used was to obtain the affirmation, on oath, of witnesses who declared a man guilty, or innocent; and the value of the oath depended on the status of the oath giver. The oath of a thegn [noble] was worth more than the oath of the 'gebur' of the village [village peasant]: the oath of a priest was worth more than the oath of a deacon, that of a deacon worth more than that of a layman. One of Cnut's laws enjoined that everyone, over twelve years of age, should take an oath that he would not be a thief or a thief's accomplice: a trustworthy man, who had never failed in oath or ordeal, was entitled to clear himself when accused within the hundred gemot [court] by a simple oath of exculpation: that is, the accused man must find two men within the hundred ready to take the oath with him that he was innocent. An 'untrustworthy man' with a bad reputation [i.e. one of ill fame], accused in the hundred gemot, must make the triple oath of exculpation: he must find twelve oath helpers to swear with him that he is innocent: or else he must go to the ordeal. Before he could be sent to the simple ordeal, three solemn oaths that he was guilty must be made to the hundred moot [meeting]; six solemn oaths before he could be sent to the triple ordeal. That is, in the case of
} 


\section{(c) Conclusion}

It is important, today, that jurors and witnesses understand the nature of the declarations they give. Further, the same should be clear and simple. Also, to avoid problems - and speed up administration - there is no reason why the court clerk (or judge or other designated party) cannot put the declaration to all the jurors, to which each of them replies with a simple 'yes'. Thus, it is asserted that, today, the oaths of jurors and witnesses should be simplified, with the court clerk (or other) saying to the:

Juror: 'Do you promise to give an honest and impartial verdict on the evidence?' Answer: 'Yes.'

Witness: 'Do you promise to tell the truth ?' Answer: 'Yes.'

On saying 'yes', the juror (witness) should then be told that - if they fail to give and honest and impartial verdict (or if they fail to tell the truth) - they may be prosecuted for giving a false verdict as a juror or giving false evidence (as a witness).

\section{(d) Affidavits}

Besides the oath of the juror and the oath of the witness, other oaths may be required in legal proceedings (civil and legal). It is asserted these should now become declarations, as opposed to oaths. And, that the form of these oaths should be laid down in rules of court (or a statutory instrument).

\section{In conclusion, oaths in legal proceedings - especially, those of a juror and a witness - should become} declarations and be simplified.

\section{THOSE AUTHORISED TO ADMINISTER OATHS}

The power of a Commissioner for Oaths to administer oaths (and affirmations) is laid out in legislation. In particular, the Commissioners for Oaths Acts 1889 and 1891 - as well as the Stamp Duty Management Act, s 24. ${ }^{273}$ Thus, the 1889 Act, s 1(appointment and powers of commissioners for oaths) provides that:

(2) A commissioner for oaths may...in England or elsewhere, administer any oath or take any affidavit for the purposes of any court or matter in England, including any of the ecclesiastical courts or jurisdictions, matters ecclesiastical, matters relating to applications for notarial faculties, and matters relating to the registration of any instrument, whether under an Act of Parliament or otherwise, and take any bail or recognizance in or for the purpose of any civil proceeding in the senior courts... (3) provided that a commissioner for oaths shall not exercise any of the powers given by this section in any proceeding ....in which he is interested.

Other extant sections of the 1889 Act deal with the;

- power of court officers to administer oaths; ${ }^{274}$

- taking of oaths out of England; ${ }^{275}$

- appointment of persons to administer oaths for prize proceedings (now, likely, obsolete);

- the jurat to state where (and when) the oath is taken;

- powers as to oaths and notarial acts abroad;

- forgery;

- trial of offences;

- impounding documents;

\footnotetext{
certain specified and grave offences, when the oaths of the accusers and the defendants were equal in value, recourse was had to the ordeal to obtain the judgment of God as to who was lying.'

${ }^{273} \mathrm{~S} 24$ (declarations, how to be made). "Any statutory declaration to be made in pursuance of or for the purposes of this or any other Act for the time being in force relating to duties may be made before any of the Commissioners, or any officer or person authorised by them in that behalf, or before any commissioner for oaths or any justice or notary public in any part of the [UK], or at any place out of the [UK], before any person duly authorised to administer oaths there.'

${ }^{274} \mathrm{~S} 2$ (powers of certain officers of court, \&c. to administer oaths). 'Every person who, being an officer of or performing duties in relation to any court, is for the time being so authorised by a judge of the court, or by or in pursuance of any rules or orders regulating the procedure of the court, and every person directed to take an examination in any cause or matter in the Senior Courts shall have authority to administer any oath or take any affidavit required for any purpose connected with his duties.'

${ }^{275} \mathrm{~S} 3$ (taking of oaths out of England). '(1) Any oath or affidavit required for the purpose of any court or matter in England, or for the purpose of the registration of any instrument in any part of the [UK], may be taken or made in any place out of England before any person having authority to administer an oath in that place. (2) In the case of a person having such authority otherwise than by the law of a foreign country, judicial and official notice shall be taken of his seal or signature affixed, impressed, or subscribed to or on any such oath or affidavit.'
} 
- definitions. ${ }^{276}$

For its part the 1891 Act, s 1, states that affidavits may be made before a commissioner of oaths at any place. Finally, the older Oaths Act 1775 provides for JP's to administer oaths ${ }^{277}$ (for public notaries, see 14(b) above). The administration of oaths is also a reserved legal activity for the purposes of the Legal Services Act 2007 (s 12). However, during a transitional period, the following are licenced to administer the same (including oaths required for foreign legal purposes), every:

- barrister with a practising certificate, ${ }^{278}$

- qualified solicitor; ${ }^{279}$

- legal partnership; ${ }^{280}$

- $\quad$ registered European lawyer, ${ }^{281}$

- licensed conveyancer;

- conveyancing partnership;

- recognised body. ${ }^{282}$

It is asserted that all this old legislation should now be repealed and who may administer a declaration should be set out in an Oaths and Statutory Declarations Act.

29. CRIME OF PERJURY

(a) Development of the Law of Perjury

Turner, the editor of the last edition of Kenny's Outlines of Criminal Law, in 1966, stated in respect of the history of this crime:

In Anglo-Saxon legal procedure, judicial oaths played a very important part, being taken both by jurors and by compurgators. Both these clauses were punishable for any perjuries they uttered. ${ }^{283}$ But the functions of the modern witness had not yet been differentiated from those of the juror; and perjury by witnesses was consequently an unknown crime. And when, in the fourteenth century, witnesses began to be brought in to inform the jury, perjury by them was not made a punishable offence. Hence it became a maxim that the law regarded every witness's oath as true. Even the ecclesiastical courts, though treating breaches of faith in general as matters within their jurisdiction, took no notice of the grave breach of faith in giving false witness. But, before the end of the fifteenth century, the Star Chamber sometimes interposed to punish perjuries. And in the sixteenth century, Parliament itself began to interfere with the immunity of witnesses, dealing in 1540 [32 Hen VIII c 9 s 3$]^{284}$ with subornation of perjury, and in 1562 with perjury itself [5 Eliz $1 \mathrm{c} 9$ ]. ${ }^{285}$ But for each of these offences it imposed only a pecuniary penalty, recoverable civilly by a penal action. Finally, however, the Star Chamber, in 1613, declared perjury by a witness to be punishable at common law. ${ }^{286}$

The offence thus created was one which could only be committed in a judicial proceeding, ${ }^{287}$ and by a witness who gave false evidence on oath. But the law gradually came to assume a far more complicated

\footnotetext{
${ }^{276}$ Ibid, ss 3-6, 8-11. In s 11 (definitions) it states: "In this Act, unless the context otherwise requires, "Oath" includes affirmation and declaration: "Affidavit" includes affirmation, statutory or other declaration, acknowledgement, examination, and attestation or protestation of honour: "Swear" includes affirm, declare, and protest.'

${ }^{277}$ See n 102.

${ }^{278}$ Halsbury, n 16, vol 66, para 858. See also Legal Services Act 2007, sch 5, paras 4(1) \& (2).

${ }^{279} \mathrm{Ibid}$, vol 65, para 534.

${ }^{280}$ Ibid.

${ }^{281}$ Ibid.

${ }^{282}$ Halsbury, n 16, vol 66, para 990 'The administration of oaths is a reserved legal activity for the purposes of the Legal Services Act 2007 and a person may be authorised to carry on such activities by the Council for Licensed Conveyancers. However, during the transitional period every licensed conveyance, every conveyancing partnership and every recognised body is deemed to be authorised by the Council to administer oaths.' A recognised body is one recognised under the Administration of Justice Act 1985, s 32. For example, the Solicitors Disciplinary Tribunal, for the purposes of any application (or complaint) made to it under the Solicitors Act 1974, may administer oaths, see Halsbury, n 16, vol 66, para 680.

${ }^{283}$ This is over-stated, see Pollock \& Maitland, n 64.

${ }^{284}$ The Bill of Bracery and buying of Titles (rep 1967), s 3.

${ }^{285}$ An Act for Punishment of such as shall procure or commit any wilful Perjury (rep 1911).

${ }^{286} R$ v Rowland ap Eliza (1613), see Coke, n 76, vol 3, 164.

${ }^{287}$ The Keepers of the Liberties $v$ Gwinn (1652) Style 336.
} 
form. Parliament specified various matters which were not judicial proceedings, yet in which telling a falsehood upon oath was to be a perjury. Again, some classes of witnesses came to be allowed by statute to give evidence in judicial proceedings on mere affirmation, without any oath; and falsehood by them, though no perjury, was made as severely punishable as if it were one. Moreover, the judges proceeded to declare that, in any matter wherein the law required an oath to be taken, the taking it falsely - if it were not judicial, and so not a perjury - would be at least a common law misdemeanour, ${ }^{288}$ punishable with fine and imprisonment, though not with the penalties of perjury. ${ }^{289}$

\section{(b) Perjury Act 1911}

In order to help clarify the law on perjury, the above Act (which is still extant) was passed. It classifies perjury into 3 grades, $\mathrm{A}, \mathrm{B}$ and $\mathrm{C}$.

- Grade A. It covers: (i) falsehood in judicial proceedings; ${ }^{290}$ (ii) false oaths in non-judicial proceedings; ${ }^{291}$ (iii) false affidavits. ${ }^{292}$ It also covers false declarations, where an oath (or affirmation) has been taken with reference to the celebration of a marriage or a birth or death. ${ }^{293}$ It does not cover breaches of a juror's oath. Nor promissory oaths. Nor where oaths are included at common law. ${ }^{294}$ The $^{2}$ punishment for an offence is 7 years imprisonment or a fine (or both);

- $\quad$ Grade B. It covers statutory declarations where no oath has been taken. Thus, it is committed when a statement is made in a statutory declaration or some other document which the offender was obliged to make (or some oral declaration or answer he was required to make) by a public general Act of Parliament. ${ }^{295}$ The punishment is 2 years imprisonment or a fine (or both);

- $\quad$ Grade C. It covers the registration of practitioners. Thus, such an offence is committed when a person makes (orally or in writing) a representation which he knows 'to be false or fraudulent' for the purpose of getting himself registered (or of procuring a certificate of someone's being registered) on the statutory roll of persons legally required to practice a particular calling. ${ }^{296}$

Subornation is committed when a person incites a person to commit an offence under the Perjury Act $1911 .^{297}$ If successful, the crime is punished the same as the perjury.

\section{(c) Abolishing the Crime of Perjury}

The crime of perjury has never been well understood and has had a chequered history. It is asserted that - if oaths are abolished - the crime of perjury should be abolished. Instead, a new Oaths and Statutory Declarations Act should punish, as distinct offences, the following:

\footnotetext{
${ }^{288} R$ v Foster (1821) R \& R 459.

${ }^{289}$ See generally, Turner, n 97, vol 1, pp 291-307. For a modern discussion of the Perjury Act 1911 see Halsbury, n 16, vol 26. Also, Archbold: Criminal Pleading, Evidence and Practice (2019).

${ }^{290}$ Perjury Act 1911, s 1(1) 'If any person lawfully sworn as a witness or as an interpreter in a judicial proceeding wilfully makes a statement material in that proceeding, which he knows to be false or does not believe to be true, he shall be guilty of perjury.' Judicial proceeding is defined to cover ( $\mathrm{s} 1(2)$ ) any proceeding 'before any court, tribunal, or person, having by law the power to hear, receive, and examine evidence on oath.' Also, 1(3) 'Where a statement made for the purposes of a judicial proceeding is not made before the tribunal itself, but is made on oath before a person authorised by law to administer an oath to a person who makes the statement, and to record or authenticate the statement, it shall, for the purposes of this section, be treated as having been made in a judicial proceeding.'

${ }^{291}$ Ibid, s 2 'If any person (1) being required or authorised by law to make any statement on oath for any purpose, and being lawfully sworn (otherwise than in a judicial proceeding) wilfully makes a statement which is material for that purpose and which he knows to be false or does not believe to be true.'

292 The wilful use of a false affidavit for the purposes of the Bills of Sale 1878, s 2(2).

${ }^{293}$ Perjury Act 1911, ss 3(1) \& 4(1).

${ }^{294}$ Turner, n 97, p 292.

${ }^{295}$ Perjury Act 1911, s 5 'If a person knowingly and wilfully makes (otherwise than on oath) a statement false in a material particular, and the statement is made - (a) in a statutory declaration; or (b) in an abstract, account, balance sheet, book, certificate, declaration, entry, estimate, inventory, notice, report, return, or other document which he is authorised or required to make, attest, or verify, by any public general Act of Parliament for the time being in force; or (c) in any oral declaration or oral answer which he is required to make by, under, or in pursuance of any public general Act of Parliament for the time being in force...'.

${ }^{296}$ Perjury Act 1911 , s 6.

${ }^{297}$ Turner, n 97, p 441 'If anyone incites a person to commit either perjury or any other offence against the [Perjury] Act, he commits...a misdemeanour for which he may be fined or imprisoned. But if his incitement prove so successful that the other man does commit the offence, there is then an actual subornation; and for this the suborner may be visited with as severe a punishment as for the perjury, or other offence, itself (section 7).' The Perjury Act 1911, s 7(1) states 'Every person who aids, abets, counsels, procures, or suborns another person to commit an offence against this Act shall be liable to be proceeded against, indicted, tried and punished as if he were a principal offender.' See also Turner, n 97, vol 1, p 302.
} 
- Giving a false verdict (as a juror); ${ }^{298}$

- $\quad$ Giving false evidence (in any judicial or legal proceedings, including as a witness or in an affidavit);

- Making a false Statutory Declaration.

The latter crime should be tailored to each specific statutory context and inserted into the relevant legislation (viz, the Bills of Sale Acts, birth, deaths and marriages legislation etc). However, there should be a residual category of making a false declaration - as in the present Grade B above (which should also apply to statutory instruments) - which residual category should also cover the registration of practitioners (i.e. Grade C). That, is Grades B and C should be conflated.

\section{In conclusion, the Perjury Act should be repealed and the crime become one of making a false declaration. \\ 30. RECONCILING SCOTS \& ENGLISH LAW}

Scots law on oaths, in Victorian times, was simpler than English law.

- In Scots trials, the oath was usually administered by the judge alone, rather than by a court officer. ${ }^{299}$

- Also, a witness was not required to hold any holy book (nor kiss it). And, the form of the oath tended to be shorter. ${ }^{300}$

- Further, in Scotland, there was (generally) more adherence to the notion that Christ had inveighed against the giving of any oath.

England caught up with such practises with the Oaths Act 1909. It permitted a Scots form of oath giving (that is, with the right hand raised and there being no requirement to hold a Bible or to kiss it). Further the Oaths Act 1909 enabled this form of oath to be used even if a person was not a Scot. ${ }^{301}$ As it is, further simplifying the law on oaths will help both English and Scots practice. Thus, it is asserted that an Oaths and Statutory Declarations Act should cover Scotland as well as the rest of the UK, if possible. ${ }^{302}$

\section{CONCLUSION}

Oaths belong to a time when - inspired by a fear of God (and a fear of being treated as a social outcast if an untrue (false) oath was given) - they had a strong moral efficacy. However, they had no legal efficacy save in the case of oaths given in judicial proceedings (as noted by Britton in 1290 and by Coke in 1641). Today, given a decline of religiosity in general (and the fact that oaths seem to have been opposed by Christ), it is asserted that all legally required oaths should be dispensed with. Thus, in particular, this article argues for some simple propositions:

- Consolidation. All legislation on oaths - and their administration - should be consolidated into an Oaths and Statutory Declarations Act. One which should be comprehensive and employ modern wording. Material on requirements relating to: (a) oaths for legal proceedings abroad; (b) affidavits and other legal documents; should be set out in an SI;

- Replacing Oaths with Statutory Declarations. All oaths (including the coronation oath) should be replaced by a statutory declaration (and all oaths required at common law, if any, should be abolished);

- $\quad$ Abolishing Most Oaths. All official oaths (including judicial oaths) along with oaths of homage and fealty, should be abolished (even in a ceremonial capacity). And, the oath of allegiance should (qua statutory declaration) now only be required from: (a) members of the armed forces, on enlistment; (b) aliens, on naturalisation. Privy Councillors should give a declaration relating to secrecy only. The coronation oath should become a declaration (also, shorn of wording agreeing to defend the legal status of the CoE). Oaths given by jurors and witnesses should be in the form of declarations;

\footnotetext{
${ }^{298}$ The Perjury Act 1911 does not cover this at present.

${ }^{299}$ Noted by Stringer ( $3^{\text {rd }}$ ed, 1910), n 15, p 131

${ }^{300}$ Ibid, p 93 'I swear by Almighty God that the contents of this my affidavit are true'. Ibid, p 138 (as a witness) 'I swear by Almighty God that I will speak the truth, the whole truth and nothing but the truth.'

${ }^{301}$ In England, there was concern from Victorian times about acquiring infection from kissing the Bible, see e.g. Stringer ( $3^{\text {rd }}$ ed, 1910), $\mathrm{n} 15$, pp vii-iii \& 84. The Oaths Act 1909 did not require this practice (but did not expressly annul it, p 3). However, it soon died out. As to nonScots being able to swear in Scots form see Ibid, pp 84-5. Also, the Scots practice of not kissing the Bible was long recognised in English law, see Williams Waher's Case (1788) 1 Leach 498 (168 ER 351). The practice of Jews swearing (some with head covered and others with head uncovered, this practiced by Christians too, especially in the case of women) would also no longer be needed, if a declaration is substituted for an oath.

${ }^{302}$ This would require consideration of the False Oaths (Scotland) Act 1933. See s 1 (false statements on oath); 2 (false statutory declarations and other false statements without oath); 3 (false declarations etc to obtain registration for carrying on a vocation); 4 (aiders, abettors, suborners etc); 5 (venue); 6 (savings); 7 (form of oath etc).
} 
- Simplifying the Formalities of Declarations. All declaration should be as simple as possible and in plain English, to assist intelligibility;

- $\quad$ Abolition of Periury. This crime should be abolished. Instead, there should be specific crimes of: (a) giving a false verdict (for a juror); (b) giving false evidence (as a witness or in an affidavit etc); (c) making a false statutory declaration.

An example of how an Act might cover the above is given in the draft Act below and its effects may be noted. This Act seeks to abolish various oaths - such as official and judicial oaths (see the draft Act below, s 1). Thus, it prevents any person or organisation requiring such in the future. Further, even when an oath is permitted by the Act - such as the oath of allegiance proposed for those enlisting in the armed forces - the oath must now be couched in the form of a declaration. It may be noted that the Oaths Act 1978 enabled a person to give an affirmation (declaration) instead of an oath in all instances. However, this Act makes the position mandatory all oaths must now be converted (transmuted) into declarations. Also, any statutory declaration (or oath required for foreign purposes) must be administered by an authorised person or else it is void. Finally, any oath not authorised by the law is unlawful and cannot be required of a person. ${ }^{303}$ This preserves the position enunciated by Coke in his work published in 1641 which was designed to prevent persons being trapped into making oaths for nefarious purposes.

\section{OATHS AND STATUTORY DECLARATIONS ACT}

\section{Abolition of Certain Oaths and Affirmations}

(1) The following are abolished, any:

(a) official oath (also, called an oath of fidelity);

(b) judicial oath;

(c) oath of homage;

(d) oath of fealty;

(e) oath of allegiance (save as provided in section 5)

(f) oath required at common law. ${ }^{304}$

(2) 'Oath' includes any affirmation (or solemn affirmation) in lieu thereof.

\section{Replacing Statutory Oaths with Statutory Declarations}

(1) All statutory oaths shall be replaced by statutory declarations.

(2) The form of any statutory declaration may be set out in a SI.

(3) Any statutory declaration (including those in sections 3 to 6) may be amended, or revoked, by a SI.

(4) 'Statutory oath' means any oath required by any general, local or private Act or statutory instrument. 'Statutory declaration' means any declaration required by any general, local or private Act or statutory instrument. 'SI' refers to a statutory instrument.

\section{Coronation Declaration}

(1) The sovereign, in the presence of the people assembled at his or her coronation, shall either audibly give (or sign) the declaration in Appendix A. It shall be administered by the Archbishop of Canterbury or the Archbishop of York (or any other bishop of this realm the sovereign shall appoint).

\footnotetext{
${ }^{303}$ Since all oaths at common law are abolished by the Act in the draft Act above and all statutory oaths must be changed into statutory declarations this, effectively, abolishes legal oath giving, save where required for foreign purposes. For example, if (at present) an organisation requires a member of its ruling council to give an oath of fidelity, the proposed Act abolishes such and a person can refuse to give the same. However, suppose the organisation (presently) requires an oath of secrecy? The proposed Act would require it to be in the form of a declaration, administered by an authorised person, and to be required by statute (which is unlikely). Such does not (and the present Oaths legislation enabling affirmations (declarations) in lieu of affirmations does not) impede a person agreeing to maintain secrecy as a matter of contract; or where legislation requires (e.g. under the Official Secrets Act). It is possible that this proposed Act might have to make an exception to any declaration of secrecy given by a common councilman of the City of London Corporation (see $\mathrm{n} 250$ ) since it is possible that the common law recognised such an oath, the Corporation being a medieval institution (see Liber Albus, $\mathrm{n} 70$, pp 36-7 for the oath as well as Pulling, n 125, pp 40-1).

${ }^{304}$ For these, see 19-22. There appeal to be no (lawful) oaths still required by the common law save for those of homage and fealty, see also n 98 .
} 


\section{Privy Council Declaration}

(1) Prior to becoming a member of Her Majesty's Privy Council, a person shall audibly give (or sign) the declaration in Appendix B.

\section{Declaration of Allegiance}

(1) The following shall audibly give (or sign) the declaration in Appendix C: (a) a person enlisting in Her Majesty's armed forces; (b) a foreign person, on naturalisation.

\section{Court and Legal Proceedings Declarations}

(1) A person, prior to becoming a juror or a witness, shall audibly give (or sign) the declaration in Appendix D.

(2) The form of any other declaration required for any other court or legal proceedings (or proceedings before Parliament) shall be set out in rules of court or a SI (or a Parliamentary Standing Order). ${ }^{305}$

\section{Administering Declarations}

(1) Save as otherwise provided in sections 3 to 6, any statutory declaration (or any oath required for legal purposes abroad) may only be administered by the following, any:
(a) Judge;
(b) Justice of the Peace;
(c) Court official;
(d) Arbitrator;
(e) Commissioner for Oaths;
(f) Public notary;
(g) Barrister with a practising certificate;
(h) Qualified solicitor;
(i) Legal partnership;
(j) Registered European lawyer;
(k) Licensed conveyancer;
(l) Conveyancing partnership;
(m) Recognised body;
(n) Person authorised by legislation or in a SI.

(2) All matters concerning (1) may be set out in a SI or rules of court (or a Parliamentary Standing Order) as appropriate.

(3) 'Judge' includes any judge of Her Majesty's courts. Court official' includes any registrar, master, court clerk; or any delegate of the same.

\section{Evidence (Overseas Authorities and Countries) ${ }^{306}$}

(1) Taking Evidence for Foreign Civil Proceedings. Any person appointed by a court (or other judicial authority) of any foreign country shall have power in the United Kingdom to administer an oath for the purpose of taking evidence for use in proceedings, not being criminal proceedings, carried on under the law of that foreign country;

(2) Admission of Oaths etc. by Representatives of Protecting Power. Where in any country or area Her Majesty has for the time being no diplomatic or consular representatives appointed on the advice of Her Government in the United Kingdom, and arrangements made on such advice are in force for the representation of interests of Her Majesty in the country or area through diplomatic or consular representatives of any other country, Her Majesty may, by an SI, empower such representatives to administer oaths and do notarial acts. An SI may prescribe the facts to be stated in the jurat by any person by whom an oath is administered by virtue of the SI; and any document purporting to have subscribed thereto the signature of any person in testimony of any oath being administered before him, and containing in the jurat a statement of the facts required to be stated therein by the SI, shall be received in evidence without proof of the signature being the signature of that person or of the facts so stated;

\footnotetext{
${ }^{305}$ For an affidavit the declaration should be 'I declare the contents of this affidavit are true'. Stringer ( $3^{\text {rd }}$ ed, 1910), n 15, p 87 noted that it was possible to give an oath in respect of an affidavit in such form in 1910.

${ }^{306}$ This replaces the Oaths and Evidence (Overseas Authorities and Countries) Act 1963. It may be better for this material to be in a SI so that it is easier to change.
} 
(3) Extension to Isle of Man and Channel Islands. Her Majesty may, by a SI, direct that any provisions of this section shall extend to the Isle of Man or any of the Channel Islands, with such adaptations or modifications as may be specified.

\section{Unlawful Declarations and Oaths}

(1) It is unlawful for a person, other than a person authorised pursuant to $\mathrm{s} 7(1)$, to administer a statutory declaration (or an oath) and any declaration (or oath) so administered is void.

(2) It is unlawful for a person to require another to give an oath unless legislation requires the same $\mathrm{e}^{307}$ and any oath so administered is void.

\section{Transitional Period}

(1) For a transitional period specified in an SI, an oath may be used in the case of s 2(1) and 6(2). However, such shall not apply to the other sections of this Act which shall come into immediate effect.

\section{1. $\underline{\text { Repeals }}$}

(1) The legislation referred to in Appendix E is repealed.

(2) This Act shall apply to England and Wales and Northern Ireland [and to Scotland]. ${ }^{308}$

\section{Appendix A: Coronation Declaration}

Declaration to be delivered by the archbishop or bishop:

'Do you promise to govern the peoples of the United Kingdom of Great Britain and Northern Ireland, Canada, Australia, New Zealand and your other territories according to their respective laws and customs?'

Sovereign: 'I promise.'

'Do you promise to cause law and justice to be executed in all your judgements?'

Sovereign: 'I promise.'

\section{Appendix B: Oath of a Privy Councillor}

Declaration to be given (or signed) by a person on becoming a Privy Councillor to the President of the Privy Council (or his delegate):

'I promise I will keep secret all matters discussed in Council.'

\section{Appendix C: Oath of Allegiance}

Declaration to be given (or signed) by: (a) a person enlisting in his Majesty's armed forces, to the enlistment officer (or delegate); (b) by a person on their naturalisation, to a designated immigration official (or delegate).

'I declare allegiance to [her Majesty Queen Elizabeth II], according to law.'

\section{Appendix D: Juror and Witness Declarations}

Declaration to be delivered by a judge or clerk of a court (or any delegate of either) to a juror (which declaration may be delivered individually or collectively):

'Do you promise to give an honest and impartial verdict on the evidence?'

'Yes'.

\footnotetext{
${ }^{307}$ The intent of the Act is to remove any requirement to give an oath, whether at common law or by statute (after a transitional period). Thus, any attempt to force another to give an oath in the future will be unlawful, save where the oath is required for foreign purposes (see e.g. 8 above).

${ }^{308}$ As noted, in the text (see 30), Scots law will need to be taken into account.
} 
Declaration to be delivered by a judge or clerk of a court (or any delegate of either) to a witness:

'Do you promise to tell the truth?'

'Yes'.

\section{Appendix E: Legislation Repealed}

\section{A. General Legislation}

Coronation Oath Act 1567 [Scots]

Bill of Rights 1688, art 1

Coronation Oaths Act 1688

Claim of Right Act 1689

Act of Settlement 1700

Maintenance of the Church of England Act 1706

Union with Scotland Act 1706

Protestant Religion and Presbyterian Church Act 1707

Union with England Act 1707 [Scots]

Oaths Act 1775

Public Notaries Act 1801

Public Notaries Act 1843

Clerical Subscription Act 1865

Parliamentary Oaths Act 1866

Promissory Oaths Act 1868

Promissory Oaths Act 1871

Parliamentary Witnesses Oath Act 1871

Commissioners for Oaths Act 1889

Commissioners for Oaths Act 1891

Accession Declaration Act 1910

Regency Act 1937

[False Oaths (Scotland) Act 1933

Oaths and Evidence etc Act 1963
Repeal the whole Act.

In article 1, delete the words 'And that every king and queen of this realm who at any time hereafter shall come to and succeed in the imperial Crown of this kingdom... shall have attained the said the age of twelve years.'

Repeal the whole Act.

Delete the words 'and that the oath hereafter mentioned be taken... and that the said oath of allegiance and other oath and declaration be abrogated. I AB do sincerely promise and swear that I will be faithful and bear true allegiance to their Majesties king William and Queen Mary. So help me God.'

In section 2, delete the words 'And that every king and queen....in the manner and form thereby prescribed'

In section 3 delete the words 'That whosoever shall hereafter come to the possession of this Crown shall join in communion with the Church of England as by law established.'

Delete section 2.

In article 25(3) delete the word 'And be it further enacted by the authority aforesaid that after the demise of Her Majesty... and town of Berwick upon Tweed and the territories thereunto belonging.'

Delete the words 'And lastly that after the decease of her present Majesty ... in prosecution of the Claim of Right.' In article 25, delete the words 'And lastly that after the decease of her present Majesty...in prosecution of the Claim of Right.' Repeal the whole Act.

In section 1, delete the word 'sworn'.

Repeal section 7.

Repeal the whole Act.

Repeal the whole Act.

Repeal the whole Act.

Repeal the whole Act.

Repeal the whole Act.

Repeal the whole Act.

Repeal the whole Act.

Repeal the whole Act.

Repeal section 4(1) and Schedule

Repeal the whole Act.] ${ }^{309}$

Repeal the whole Act.

\section{B. Statutory Instruments ${ }^{310}$}

The following are repealed:

- The Admission of Oaths (Summary Appeal Court)(Air Force) Order 2000/2378

- The Admission of Oaths (Summary Appeal Court)(Army) Order 2000/2377

- $\quad$ The Admission of Oaths (Summary Appeal Court)(Navy) Order 2000/2376

- $\quad$ The First-Tier Tribunal for Scotland (Oaths) Regulations SI 2017/148

- Welsh Courts (Oaths and Interpreters) Rules 1943

- $\quad$ Form of Jurors Oath Order (Northern Ireland) 1996 no 268

- $\quad$ Promissory Oaths Order 1939 SI 1939/916

- $\quad$ The Health Services (Promissory Oaths) Regulations (Northern Ireland) 1948 SI 1948/117

- The Health Services (Promissory Oaths) (Amendment) Regulations (Northern Ireland) 1951 SI 19518/100

- The Welsh Forms of Oaths and Affirmations (Government of Wales Act 2006) Amendment Order SI 2011/594

- The Welsh Forms of Oaths and Affirmations (Government of Wales Act 2006) Order SI 2007/2044

- The National Assembly for Wales (Oath of Allegiance in Welsh) Order SI 1979/1101

- $\quad$ The Citizenship Oath and Pledge (Welsh Language) Order SI 2007/1484

- $\quad$ Act of Adjounal (Form of Oaths) 1976 no 72 (S 11)

- The Commissioners for Oaths (Prescribed Bodies) Regulations SI 1995/1676

${ }^{309}$ Alteration is required to the draft Act if it is to cover Scots law.

${ }^{310}$ All this material should be placed in one SI. 
- The Commissioners for Oaths (Prescribed Bodies) Regulations SI 1994/1380

- The Commissioners for Oaths (Authorised Persons)(Fees) Order 1993/2298 ${ }^{311}$

- The Oaths and Evidence (Guernsey) Order 1966/1019

- The Oaths and Evidence (Isle of Man) Order 1965/1129

\section{BOOK OF OATHS - LIST OF OATHS}

Garnet, in his Book of Oaths (1715), gave a long list of oaths extant in his time. These may be analysed as follows. The Norman system of land tenure from 1066 was one persons receiving land from the Crown in return for the performance of a service (military, eccelesiastical or common, the latter being agricultural). These services were categorised (see 19(a)) as follows:

- Knight service;

- $\quad$ Sarjeanty service (great and small);

- Frankalmoign and divine service;

- Common socage service, this, also, being the residual service tenure.

All oaths, post-Norman Conquest, derived from these. By 1715, this was reflected in the following, oaths of:

- Homage; ${ }^{312}$

- $\quad$ Fealty (later, referred to as fidelity) $;^{313}$

- Allegiance; $;^{314}$

- An ecclesiastical nature (i.e. oaths of CoE officials). ${ }^{315}$

To administer the realm, the sovereign summoned his assembly (Parliament) from time to time. He also maintained an inner council (the privy council) and his government (viz. secretaries of the State, cabinet). By 1715, such was reflected in oaths of allegiance (and fidelity, in respect of the latter two) given by:

- Members of Parliament; ${ }^{316}$

- Privy Councillors; ${ }^{317}$

- Secretaries of State (inc. the Lord Privy Seal). ${ }^{318}$

The maintenance of the king's courts resulted in oaths given by:

- Judges and JP's;

- Justices (of Eyre, goal delivery etc) and sheriffs (now obsolete);

- Officers of various courts (now obsolete) $;^{319}$

- Sarjeants and Attornies-at-Law. ${ }^{320}$

\footnotetext{
${ }^{311}$ The following also appear to be extant:The Commissioners for Oaths (Fees) Order 1993/2297, The Commissioners for Oaths (Fees) Order (Northern Ireland) 1993/418, The Commissioners for Oaths Fees (no 2) Order 1988/998, The Commissioners for Oaths Fees Order 1988/743, The Commissioners for Oaths (Fees) Order (Northern Ireland) 1988/249, The Commissioners for Oaths (Fees) Order 1984/481, The Commissioners for Oaths (Fees)(Northern Ireland) Order 1984/223, The Commissioners for Oaths (Fees)(Northern Ireland) Order 1980/437, The Commissioners for Oaths (Fees) Order 1980/70, The Commissioners for Oaths (Fees) Rules (Northern Ireland) 1977/348, The Commissioners for Oaths (Fees) Order 1975/1972, The Commissioners for Oaths (Fees) Order 1972/1188.

${ }^{312}$ Garnet, $\mathrm{n} 15$, pp 66, 109 \& 138 cited oaths of homage given by an archbishop, the Scots king and a temporal lord,.

${ }^{313}$ Ibid, pp 133, $201 \& 74$ referring to oaths of fealty given by, inter alia, the Scots king and a bishop. The oath of fealty related to land holding. However, it came to be applied to many government officials who were not holding land in return. Thus, the oath (one of promising to perform faithful service) became one of fidelity (and, later, was called an official oath).

${ }^{314}$ Garnet also referred to oaths given by: (a) military officers; (b) captains of a band (in Berwick); (c) commissioners for executing the commissions in the diocese of York for mustering and putting subjects in readiness for war; (d) members of the Council of War; (e) the Lieutenant of the Tower of London (Garnet, n 15, pp 150-1). For oaths at a court martial, see Ibid, App, p 21,

${ }^{315}$ Garnet referred to the oath of: (a) homage by an archbishop (n 15, p 66); (b) a bishop, which acknowledged the supremacy of the sovereign over that of the pope (Ibid, p 74); (c) a bishop, renouncing the pope's bull of excommunication (Ibid, p 137); (d) a bishop, of fidelity (Ibid); (e) a churchwarden (Ibid, pp 222-4); (f) a seminary priest; (g) a nun entering a cloister.

${ }^{316}$ See Garnet, n 15, p 261 (oath of allegiance). For the declaration by MP's against transubstantiation, ibid, p 240.

${ }^{317}$ Ibid, pp 3-5, 75-6.

${ }^{318}$ Ibid, pp 76-8. For the oath of the Lord Privy Seal, Ibid, p 76.

${ }^{319}$ For example, (a) the Court of Augmentations (it dealt with monastery land); (b) Court of Chancery; (c) Court of Survey (i.e. the court of general surveyors of the sovereign's land); (d) Court of Wards and Liveries; (e) Sheriff's Court; (f) Mayor's Court; (g) Court Leet; (h) Court Baron; (i) Court of Exchequer; (j) Court of First Fruits (i.e. the court of first fruits and tenths ecclesiastical); (k) Court of Requests. Oaths were given by the treasurer, clerk, auditor, master, receiver, attorney, solicitor, surveyer etc of these courts. Also, by the Baron, treasurer, chamberlain and usher of the Court of Exchequer (and their deputies). For these courts, see Coke, n 76, vol 4.
} 
At trial, there were also oaths given by the jury bailiff and jurors, among others. ${ }^{321}$ Further, in legal proceedings generally, oaths were given - such as those of executors and administrators. ${ }^{322}$ Finally, the organs of Government (administration) resulted in oaths given by officials, such as:

- $\quad$ Clerks; ${ }^{323}$

- Chancellors; ${ }^{324}$

- Auditors; ${ }^{325}$

- Customs officers (including comptrollers, searchers and customers) $;^{326}$

- Royal Household servants (inc. those who maintained Royal forests). ${ }^{327}$

Besides these, Garnet referred to various oaths relating to London which was (from ancient times) a Royal burgh and the capital of England. Thus, he referred to Corporation of London oaths ${ }^{328}$ as well as other London oaths. ${ }^{329}$ Garnet also referred to oaths given in various professions (these would, first, have originated in London). ${ }^{330} \mathrm{He}$ also, referred to various declarations given in 1702, in lieu of an oath. ${ }^{331}$ Finally, it may be noted that, by 1702 , many of the oaths referred to above had become statutory.

In conclusion, given that all oaths (including those referred to by Garnet in 1715) derived from Norman forms of service to the Crown, it is unsurprising that the Promissory Oaths Act 1868 categorised most oaths into just two main categories: (a) oaths of allegiance; and (b) official oaths (also, called oaths of fidelity, which include judicial oaths).

\section{Copyright}

Copyright for this article is retained by the author(s), with first publication rights granted to the journal.

This is an open-access article distributed under the terms and conditions of the Creative Commons Attribution license (http://creativecommons.org/licenses/by/4.0/).

\footnotetext{
${ }^{320}$ Garnet also referred, in particular, to the oath given by an attorney of the: (a) Sheriff's court; (b) Court of Augmentations; (c) Mayor's Court; (d) Court of Wards; (e) Court of First Fruits; (f) Court of Survey. See also n 319.

${ }^{321}$ Garnet referred, in particular, to the oath of a jury to try: (a) a nisi prius; (b) a traverse; (c) a prisoner at the bar (in this case, the oath was, see Garnet, n 15, p 111,'You shall well and truly try and true deliverance make between our sovereign lord the king and the prisoners at the bar, whom you shall have in charge according to your evidence. So help you God'); (d) a jury of women.

${ }^{322}$ Also, in relation to the submission of evidence e.g. Garnet, n 15, pp 112-4. e.g (oath for evidence on arraignment of the prisoner at the bar 'The evidence that you shall give to this inquest against the prisoner at the bar shall be the truth, and the whole truth and nothing but the truth as near as God shall give you grace. So help you God, and by the contents of this book.').

${ }^{323}$ In particular, Garnet referred to the clerk of the: (a) Court ofAugmentations; (b) Court of Chancery; (c) Council to the Prince (later, Charles I (1625-49)); (e) Court of First Fruits; (f) Court of Wards and Liveries; (g) Parliament (i.e. the Clerk of Parliament, see Garnet, $\mathrm{n}$ 15, pp 35-6); (h) Petty Bag (responsible for admission to, and the surrender of, Chancery offices); (i) Court of Common Pleas; (j) Signet; (k) Statutes; (1) Court of Survey; (m) Privy Council (Ibid, p 5).

${ }^{324}$ In particular, Garnet referred to the chancellor of: (a) England: (b) Court of Augmentations; (c) Court of the Exchequer; (d) Court of First Fruits.

${ }^{325}$ Garnet referred, in particular, to the oath of the auditor of the: (a) Court of Augmentations; (b) Court of Wards and Liveries; (c) Court of Survey; (d) Court of the Exchequer.

${ }^{326}$ In particular, Garnet referred to comptroller of: (a) the King's Household; (b) the Pipe Rolls; (c) Customs.

${ }^{327}$ In relation to Royal forests, Garnet referred to: (a) verderers; (b) foresters; (c) rangers; (d) regarders; (e) inhabitants of the forest. Also, to officers dealing with heraldry such as the Garter King of Arms (Garnet, n 15, p 58), Herald of Arms (ibid, pp 61-3) and Pursevant at Arms (ibid, pp 63-4). Also, others such as the Keeper of the Great Seal (ibid, p 78, for the oath of the clerk of the signet, see p 81), Keeper of the king's State papers etc.

${ }^{328}$ In particular, Garnet referred, to the oaths of the: (a) Mayor; (b) Sheriffs; (c) Aldermen; (d) Common Sarjeant; (e) Recorder; (f) Common Council members; (g) Town Clerk; (h) freeman

${ }^{329}$ In particular, Garnet referred to oaths given by: (a) an appraiser (of goods); (b) a ward beadle; (c) a broker; (d) a scavenger; (e) a tronator (i.e. an official in charge of the weighing of things, especially wool); (f) constable (i.e. a policeman). Also, by a garnishee, on attachment in London.

${ }^{330}$ E.g. by (a) an ale taster in a court leet; (b) an alneger (one who measured cloth); (c) a leather searcher (i.e. a leather inspector); (d) a midwife.

${ }^{331}$ In particular, Garnet referred to declarations given by: (a) officers of corporations (who gave an oath of non-resistance under the Corporation Act 1661, see n 123); (b) those in CoE orders and schoolmasters (who gave an oath of allegiance); (c) various persons (including MP's) who gave a declaration against transubstantiation.
} 